Portland State University

PDXScholar

$1-20-2006$

\title{
Deer-Vehicle Accident Hotspots in Northwest Clackamas County, Oregon
}

Linda K. Anderson

Portland State University

Follow this and additional works at: https://pdxscholar.library.pdx.edu/open_access_etds

Part of the Human Geography Commons, and the Nature and Society Relations Commons Let us know how access to this document benefits you.

Recommended Citation

Anderson, Linda K., "Deer-Vehicle Accident Hotspots in Northwest Clackamas County, Oregon" (2006). Dissertations and Theses. Paper 4968.

https://doi.org/10.15760/etd.6843

This Thesis is brought to you for free and open access. It has been accepted for inclusion in Dissertations and Theses by an authorized administrator of PDXScholar. Please contact us if we can make this document more accessible: pdxscholar@pdx.edu. 


\title{
DEER-VEHICLE ACCIDENT HOTSPOTS IN \\ NORTHWEST CLACKAMAS COUNTY, OREGON
}

\author{
by \\ LINDA K. ANDERSON
}

\begin{abstract}
A thesis submitted in partial fulfillment of the requirements for the degree of
\end{abstract}

\section{MASTER OF SCIENCE in GEOGRAPHY}

Portland State University 2006 


\section{THESIS APPROVAL}

The abstract and thesis of Linda K. Anderson for the Master of Science in Geography were presented January 20, 2006, and accepted by the thesis committee and the department.

COMMITTEE APPROVALS:

Keith Hadley, Chair

Joseph Poracsky

Heejun Chang

J. Alan Yeakley

Representative of the Office of Graduate Studies

DEPARTMENT APPROVAL:

Martha Works, Chair

Department of Geography 


\begin{abstract}
An abstract of the thesis of Linda K. Anderson for the Master of Science in Geography presented January 20, 2006
\end{abstract}

Title: Deer-Vehicle Accident Hotspots in Northwest Clackamas County, Oregon

Road-kill of wildlife is common on Portland, Oregon's suburban fringe where development has increased road densities and traffic volume in rural areas. I identify the spatial and temporal patterns of black-tailed deer (Odocoileus hemionus collmbiams) deer-vehicle accidents (DVA) at the suburban/rural interface of developing northwest Clackamas County using deer carcass pickup reports for county* maintained roads for 1997-2004 and Oregon Department of Transportation deervehicle accident reports for 1996-2004. No black-tailed deer DVA models exist in the literature.

DVA increased $121 \%$ from 1997 to 1999 followed by a $26 \%$ decline by 2004 . The initial DVA increase appears related to population growth and development into rural areas, an increase in the average daily vehicle-trip distance, and deer immigration from public lands. The subsequent decline appears related to DVA-induced decreases in deer populations, year-around hunting permits, growing predator populations, and fawning habifat loss. 
Temporal DVA patterns for black-tailed deer show a minor peak in June-July and a major peak in October-November. Forfy-two percent of DVA occur during the rut/hunt months of September, October, and November. This pattem corresponds to the black-tail's annual cycle and resembles pattems reported for white-tailed deer (Odocoileus virginianus) and mule deer (Odocoileus hemionus hemioms), Weekly DVA increased from a low on Sunday to a high on Friday and Saturday. DVA showed two daily peaks at 0500-0700 and 1800-2200, corresponding to dawn and dusk when deer activity is highest.

I identified 19 DVA hotspots with 16-27 DVA using CrimeStat III statistical clustering software. Hotspots occurring in rut/hunt months were separate from hotspots occurring in nomrut/nonhunt months. Similar to white-tailed and mule deer, black-tailed DVA hotspots commonly accurred where roads intersect or parallel water features, large forest blocks, and other areas of cover, or separate food sources from cover. Sixty-five percent of DVA occured outside of hotspots with $\geq 10$ DVA.

Deer-vehicle accidents have important ecological and economic costs and are frequent on northwest Clackamas County roads. Additional research supported by multi-agency carcass pickup reporting and the acquisition of precise DVA locations using a Global Positioning System (GPS) is needed to better identify wildlife movement corridors. 


\section{ACKNOWLEDGMENTS}

Grateful thanks to my advisor, Keith Hadley, for your careful tutelage, time, good counsel, and unfailing support. You are such a talented teacher! I'm glad our ships passed. Thanks also to my committee members and great teachers, Joe Poracsky, Heejun Chang, and Alan Yeakley, for your expertise, guidance and time, both in the classroom and during the thesis process.

Much gratitude to Victor Walsh, my employer. You were always on my side, buoyed my spirits with your stories about late-achievers, kept me employed, and gave me flexible hours and days, even when it was more to my advantage than to yours. My achievement belongs to you as well as to me.

Gratitude and love to the late Richard Forbes, Professor of Biology. You taught me so much, so well, and in such a respectful fashion, helping me to channel my fascination with living things. Such a precious, life-long gift! You said to me after reading my last exam, "Linda, it was like you were in my head while writing this." I recall replying, "That's because there's so much of you in my head." Truly, you will always live on, in my head and my heart!

Thanks to my family for your patience. I'm finally graduating! You will no longer have to introduce me as "the life-long learner!" Thanks to Ron Skidmore for your generously given expertise on Clackamas County! Thanks also to Angelica Nelson for your skillful, good-natured assistance. I enjoyed our conversations about food. Finally, thanks to my fellow graduate students. I enjoyed getting to know each of you, was impressed by your ability, and heartened by your kindness. 


\section{TABLE OF CONTENTS}

PAGE

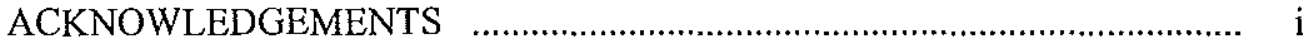

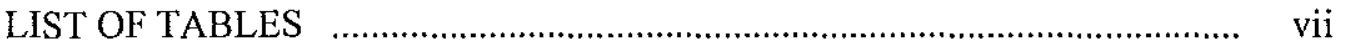

LIST OF FIGURES

\section{CHAPTER}

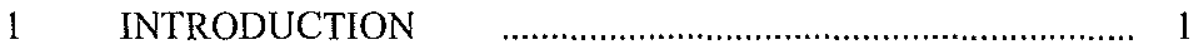

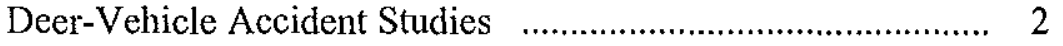

Black-Tailed Deer ................................................................... 7

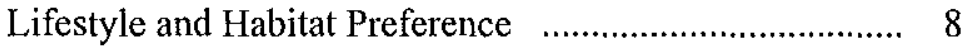

Home Range …................................................... 10

Daily and Seasonal Movement ................................... 12

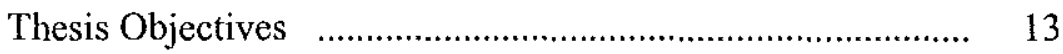

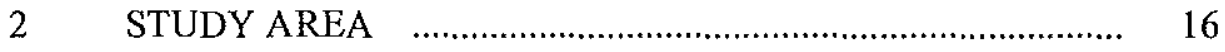

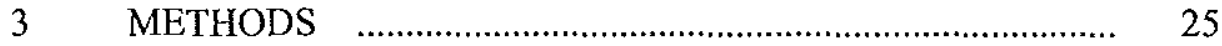

Data Sources ….................................................................... 25

Deer Carcass Pickup Reports ................................... $\quad 25$

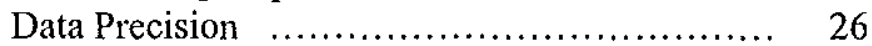

Deer-Vehicle Accident Reports .................................. 28

Sunrise and Sunset ................................................... 29

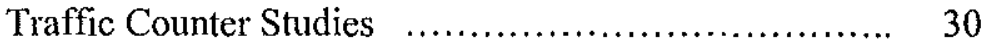

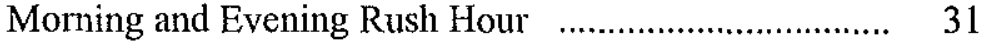

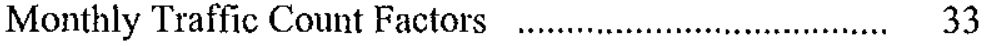

Defining Deer-Vehicle Accident Hotspots ................... $\quad 34$ 
Literature Definitions of DVA Hotspots $\ldots . . . \ldots \ldots \ldots \ldots \ldots . . . . . . . . .34$

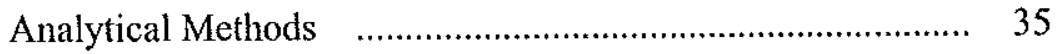

Spatial and Temporal DVA Patterns $\quad$............................... 35

Annual and Seasonal DVA Pattern $\ldots . . . \ldots \ldots \ldots \ldots \ldots . . . . . . . .35$

Day-of-Week DVA Pattem $\ldots \ldots \ldots \ldots \ldots \ldots \ldots . . . \ldots 37$

Daily DVA Pattern $\ldots \ldots \ldots \ldots \ldots \ldots \ldots \ldots \ldots . . . \ldots . \ldots$

Deer-Vehicle Accident Hotspots $\quad$................................. $\quad 39$

Defining Clackamas County DVA Hotspots $\quad$.................. 39

Identifying the Spatial Extent of Hotspots 41

Seasonal Shifts of DVA Hotspot Locations ........ 42

Landscape Characteristics of DVA Hotspots $\quad \ldots . . .43$

Vehicle Speed, Traffic Volume, and Road Class of DVA Hotspots .................. 44

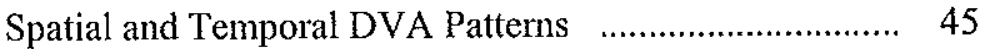

Annual and Seasonal DVA Patterns $\quad \ldots \ldots \ldots \ldots \ldots \ldots . . . . . . . .45$

Seasonal DVA and Deer Activity Patterns $\quad$......... 49

Day-of-Week DVA Pattern ............................... 51

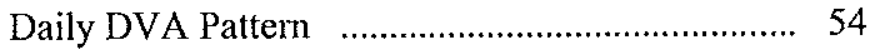

DVA Hotspot Identification 
Percent of DVA Occurring Outside of Hotspots 65

Seasonal Shifts of DVA Hotspot Locations $\ldots . . . .66$

Landscape Characteristics of DVA Hotspots ..... 67

Vehicle Speed, Traffic Volume, and Road Class of DVA Hotspots ..................... 69

Temporal Patterns of Deer-Vehicle Accidents .............. 70

Seasonal DVA Patterns $\quad$........................................ 71

Day-of-Week DVA Pattern .............................. 74

Daily DVA Pattern ....................................... 75

Deer-Vehicle Accident Hotspots ................................. 76

Identifying Hotspot Locations $\quad$........................... 78

Identifying DVA Density Along Road Segments .. 78

Seasonal Shifts of DVA Hotspot Locations ....... 79

Characteristics of DVA Hotspots $\quad \ldots \ldots \ldots \ldots \ldots . \ldots 79$

Buildings ................................................. 80

Natural and Human-created Corridors ...... 80

Water Features ......................................... 81

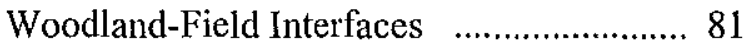

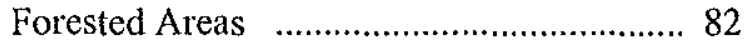

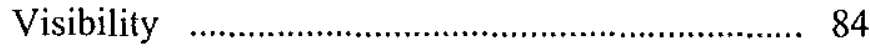

Vehicle Speed, Traffic Volume, and Road Class .. 85 
PAGE

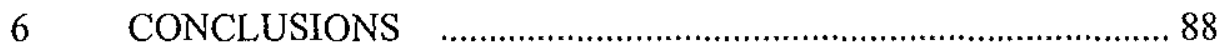

Temporal DVA Patterns $\quad$............................................... 89

Population Growth and Development $\ldots \ldots \ldots \ldots . . .89$

Factors Influencing Black-Tailed Deer

Populations $\ldots \ldots \ldots \ldots \ldots \ldots \ldots \ldots \ldots . \ldots 9$

Seasonal DVA Pattern

Daily DVA Pattern $\quad \ldots \ldots \ldots \ldots \ldots \ldots \ldots \ldots \ldots \ldots . \ldots 2$

DVA Spatial Patterns .................................................... 92

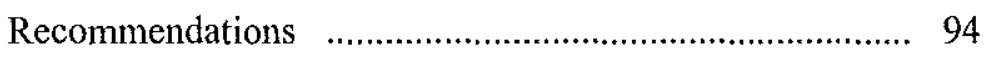

Maintain Carcass Pickup Reports with GPS Location ....................................... 94

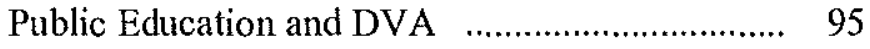

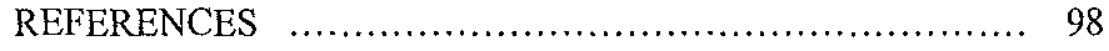

APPENDICES F............................................................... 110

A Population Growth in Clackamas County, 1990-2003 $\ldots \quad 111$

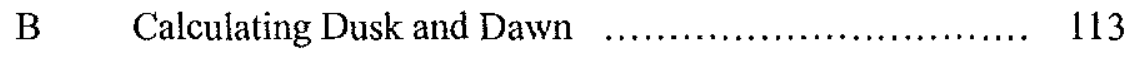

Table B.1. Nautical Twilight, Sunrise, and Sunset $\ldots \ldots \ldots \ldots \ldots . . \ldots 114$

Table B.2. Dawn, Dusk, Dusk + 2 Hours, Morning and Evening Rush Hours $\ldots \ldots \ldots \ldots \ldots \ldots \ldots \ldots \ldots . .115$

C Congestion Frequency on I-205 f.................... 116

D Natural Breaks in the Distribution of DVA Frequencies .. 118

E Nearest Neighbor Clustering Routine Results _........ 120 
PAGE

F Clackamas County Hotspots: Landscape Characteristics And Locations

Figure F.1. Six DVA Model Factors $\quad \ldots \ldots \ldots \ldots \ldots \ldots \ldots \ldots \ldots, 124$

Figure F.2. DVA Model Visibility Factors $\quad \ldots \ldots \ldots \ldots \ldots \ldots \ldots . . \ldots 125$

Figure F.3. Union Mills Road Hotspot Orthophoto $\ldots \ldots \ldots \ldots \ldots .126$

Table F.1. White-tailed and Mule Deer DVA Model Factors In the 19 Largest Clackamas County DVA Hotspots

Table F.2. Nineteen Largest Hotspots by Hotspot Identification Number, with Location, Length, DVA Number .. 128

Table F.3. Hotspots with < 16 DVA, with Location, DVA Number, and DVA Density

G Hotspot Traffic Conditions 133 


\section{LIST OF TABLES}

TABLE

PAGE

1. Characteristics of roads with deer-vehicle accidents ................... 3

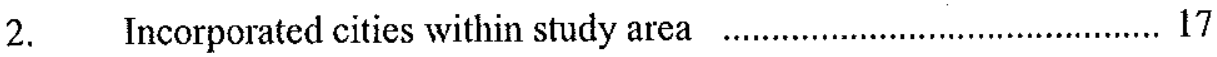

3. Census population and inter-censal population estimates f............ 19

4. Annual new, privately-owned residential building permits $\ldots \ldots \ldots . . .20$

5. Vehicle miles traveled on state-owned highways f................... 21

6. Road mileage for county rural roads, county municipal extensions, county local access, state highway system, and roads owned by cities in Clackamas Count ............................. 22

7. Number of registered drivers and number of registered vehicles .. 24

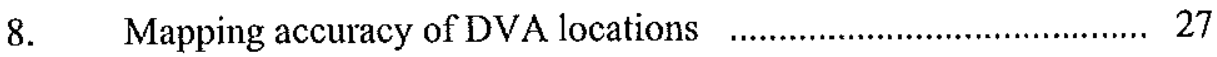

9. Morning and evening traffic volume peaks for I-205, Redland Road, and Beavercreek Road …...................................... 32

10. Defining criteria of DVA hotspots in DVA hotspot models

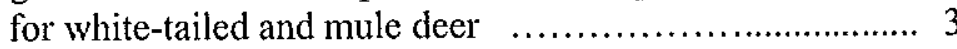

11. Months of year in 3- and 4-month deer seasonal cycles and in climate season 38

12. Landscape, land use, and visibility variables examined for contribution to deer-vehicle accident hotspots

13. Annual and monthly summary statistics for deer carcass pickups

14. Percentage of DVA occurring during the rut months 
15. Day-of-week DVA as percentage of monthly DVA $\ldots \ldots \ldots \ldots \ldots \ldots . . . . . .52$

16. Overlap of DVA with morning and evening rush hours, dawn,

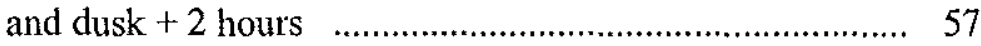

17. Comparison of DVA density for DVA hotspots $\ldots \ldots \ldots \ldots \ldots \ldots \ldots \ldots . . . \ldots 3$

18. Frequency of DVA hotspots containing $\geq 10$ DVA $\ldots \ldots \ldots \ldots \ldots \ldots . . . \ldots 5$

19. DVA hotspot cluster identification number and number of DVA in cluster for rut months $\ldots \ldots \ldots \ldots \ldots \ldots \ldots \ldots \ldots \ldots \ldots \ldots \ldots . . . . .67$

20. DVA hotspot model factor presence in 19 largest hotspots $\ldots \ldots 68$ 


\section{LIST OF FIGURES}

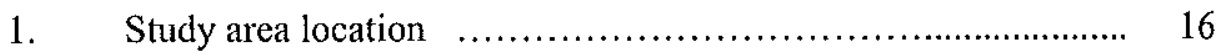

2. Registered vehicles and registered drivers in Clackamas County .. 23

3. Average traffic volume on Redland and Beavercreek Roads ..... 33

4. Frequency of other DVA within $0.5 \mathrm{mi}$ search radius of every DVA

5. Annual pattern of carcass pickups $\ldots \ldots \ldots \ldots \ldots \ldots \ldots \ldots \ldots \ldots . \ldots \ldots$

6. Carcass pickups by month for all years combined f.................... 46

7. Carcass pickups for all months and all years f.......................... 48

8. ODOT deer-vehicle accident reports by month, all years for Clackamas, Washington, and Multnomah Counties ... 48

9. Correspondence between black-tailed deer annual life cycle and annual DVA cycle

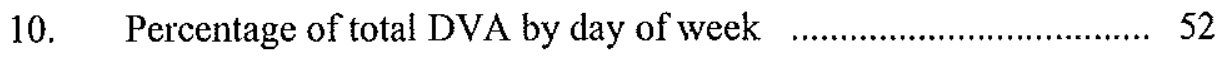

11. Percentage of monthly DVA occurring on each day of week ..... 53

12. ODOT deer-vehicle accident reports by hour, all months

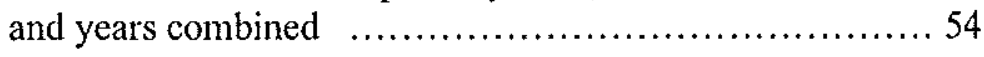

13. ODOT deer-vehicle accident reports by hour, all months and years, for Clackamas, Washington, and Multnomah Counties, 1996-2004

14. Overlap of Clackamas County DVA with dawn, dusk, morning and evening rush hours 
PAGE

15. Locations with more than one DVA ........................................ 60

16. Frequency of DVA within a 0.5 mi radius of each DVA ........... 61

17. DVA hotspot clusters with $\geq 10$ DVA at 0.5 mi search radius .... 64

18. Rut/hunt and nonrut/nonhunt DVA hotspots overlap showing two areas of seasonal overlap ........................... 66 


\section{CHAPTER 1}

\section{INTRODUCTION}

Deer-vehicle accidents (DVA) are a growing concern among transportation planners, wildlife managers, insurance companies, and users of the approximately four million miles of U.S. public roads (Romin and Bissonette 1996a, Riitters and Wickham 2003). Conover et al. (1995) estimated that at least one million deer were killed annually on U.S. public roads during the mid-1990s, with approximately $4 \%$ of these accidents causing human injury and $0.029 \%$ causing a human fatality (Rue 1989). Although the cost of human injuries resulting from deer-vehicle accidents has not been estimated, the Federal Highway Administration has assigned a monetary loss associated with a human fatality at $\$ 1.5$ million (Romin and Bissonette $1996 \mathrm{~b}$ ). In the mid-1990s, deer-vehicle accidents caused an estimated $\$ 1.1$ billion in vehicle damage annually (Conover et al. 1995).

Deer-vehicle accident frequency has undoubtedly increased in the decade since the Conover et al. (1995) research was published. Deer populations are increasing and urban development continues to envelop wildlife habitat (Nielsen et al. 2003). In $1990,80 \%$ of the U.S. population lived in 274 metropolitan areas covering $20 \%$ of the country's land area (Heimlich and Anderson 2001). Between 1990 and 2000, human populations in and around some metropolitan areas increased by $3-5 \%$, while associated land development increased by 50\% (DeStefano and DeGraaf 2003). 
Deer-vehicle accidents tend to be highest at the suburban fringe where human development has increased population density, road density, and traffic volume (VanDruff et al. 1994), and human activity interfaces with deer population density and activity (Hindelang et al. 1999). These areas of rapid, low-density development, often characterized by house lots 0.5 ha to $>4$ ha, incorporate large areas of rural land and increase dependence on the automobile by further separating essential places such as home, school, work place, and stores (Heimlich and Anderson 2001). Consequently, the number of vehicles, vehicle speed, and total number of vehicle-miles driven have increased dramatically, further contributing to an increase in animal-vehicle accidents (Cook and Daggett 1995, Oregon Department of Transportation 2005; Weinman, personal communication, 2005).

\section{Deer-Vehicle Accident Studies}

Studies examining deer-vehicle accident distributions have shown that accident sites tend to cluster in "hotspots," locations where deer are frequently hit by vehicles (Bashore et al. 1985, Romin and Bissonette 1996a, Hubbard et al. 2000, Nielsen et al. 2003). This has led to the development of landscape models that identify characteristics of roads with high DVA, for the purpose of predicting and mitigating road-kill hotspots (Table 1). 
Table 1. Characteristics of roads with high and low deer-vehicle accidents based on white-tailed deer research (1969-2003) and mule deer research (Romin and Bissonette 1996a). Research listed from most recent (2003) to earliest (1969) publication dates.

\begin{tabular}{|c|c|c|}
\hline $\begin{array}{c}\text { Author/ } \\
\text { Date }\end{array}$ & Study Site & $\begin{array}{c}\text { Characteristics of Roads with High DVA } \\
\text { and Low DVA } \\
\end{array}$ \\
\hline $\begin{array}{l}\text { Nielsen et al. } \\
2003\end{array}$ & $\begin{array}{l}\text { Minneapolis, MN: } \\
2 \text { suburbs } \\
61 \% \text { residential } \\
33 \% \text { greenspaces } \\
6 \% \text { open water }\end{array}$ & $\begin{array}{l}\text { High DVA: } \\
\text { - } \quad \text { Fewer buildings } \\
\text { - } \quad \text { Higher landscape diversity } \\
\text { - } \quad \text { Higher \% forest cover } \\
\text { - } \quad \text { More public land patches }\end{array}$ \\
\hline $\begin{array}{l}\text { Hubbard et al. } \\
2000\end{array}$ & $\begin{array}{l}\text { Iowa: all state \& } \\
\text { federally } \\
\text { maintained } \\
\text { highways. } \\
\text { Mixed habitat }\end{array}$ & $\begin{array}{l}\text { High DVA: } \\
\text { - Large grass patch size } \\
\text { - Large number of woody patches with } \\
\text { interior areas }>50 \mathrm{~m} \text { from edge } \\
\text { - More bridges (associated with travel } \\
\text { corridors) } \\
\text { - More lanes of traffic } \\
\text { Low DVA: } \\
\text { - Large crop fields }\end{array}$ \\
\hline $\begin{array}{l}\text { Finder et al. } \\
1999\end{array}$ & $\begin{array}{l}\text { Illinois: } \\
98 \text { out of } \\
102 \text { counties. } \\
\text { Mixed habitat }\end{array}$ & $\begin{array}{l}\text { High DVA: } \\
\text { - Adjacent forest cover } \\
\text { - Adjacent gullies } \\
\text { - Riparian travel corridors crossing road } \\
\text { - Public recreational land within } .8 \mathrm{~km} \\
\text { - Greater landscape diversity } \\
\text { - Shorter distance between nearby forest } \\
\quad \text { patches }\end{array}$ \\
\hline
\end{tabular}




\begin{tabular}{|c|c|c|}
\hline $\begin{array}{c}\text { Author/ } \\
\text { Date }\end{array}$ & Study Site & $\begin{array}{c}\text { Characteristics of Roads with High DVA } \\
\text { and Low DVA }\end{array}$ \\
\hline $\begin{array}{l}\text { Romin \& } \\
\text { Bissonette } \\
\text { 1996a }\end{array}$ & $\begin{array}{l}\text { Utah: } \\
\text { US 40, SR } 32 \& \\
\text { SR } 248 . \\
\text { Valley habitats w/ } \\
\text { mesic meadow, } \\
\text { riparian areas, } \\
\text { pasture lands. } \\
\text { Drainage slopes w/ } \\
\text { pinyon pine, } \\
\text { juniper, sage } \\
\text { brush-grass }\end{array}$ & $\begin{array}{l}\text { High DVA: } \\
\text { - Higher traffic volume } \\
\text { - Higher deer populations } \\
\text { - Higher percent cover } \\
\text { - } \text { Adjacent drainage areas } \\
\text { - Inclined right-of-ways } \\
\text { Low DVA: } \\
\text { - Agricultural areas (abundant forage } \\
\text { away from road) }\end{array}$ \\
\hline $\begin{array}{l}\text { Bashore et al. } \\
1985\end{array}$ & $\begin{array}{l}\text { Pennsylvania: } \\
\text { 2-lane highways. } \\
\text { Long, narrow } \\
\text { mountain ridges } \\
\text { w/hardwood/pine } \\
\text { forest. Valleys w/ } \\
\text { farmland, isolated } \\
\text { woodlots, } \\
\text { residential \& } \\
\text { industrial areas }\end{array}$ & $\begin{array}{l}\text { High DVA: } \\
\text { - Shorter visibility } \\
\text { - Decreasing distance of woodland to } \\
\text { road } \\
\text { - Woodland/field interfaces } \\
\text { - Straight stretches of road (better } \\
\text { visibility induces higher speed) } \\
\text { Low DVA: } \\
\text { - Increased building density } \\
\text { - Fully repaired fencing along roads }\end{array}$ \\
\hline $\begin{array}{l}\text { Carbaugh et } \\
\text { al. } \\
1975\end{array}$ & $\begin{array}{l}\text { Pennsylvania: } \\
12.9 \mathrm{~km} \text { of } \\
\text { Interstate } 80 .\end{array}$ & $\begin{array}{l}\text { High DVA: } \\
\text { Highway runs between wooded areas where } \\
\text { deer bed during the day and agricultural } \\
\text { areas where deer feed during the night }\end{array}$ \\
\hline
\end{tabular}




\begin{tabular}{|c|c|c|}
\hline $\begin{array}{l}\text { Author/ } \\
\text { Date }\end{array}$ & Study Site & $\begin{array}{c}\text { Characteristics of Roads with High DVA } \\
\text { and Low DVA }\end{array}$ \\
\hline $\begin{array}{l}\text { Puglisi et al. } \\
1974\end{array}$ & $\begin{array}{l}\text { Pennsylvania: } \\
\text { Interstate } 80 . \\
\text { Oak-hickory forest } \\
\text { w/ occasional } \\
\text { farms }\end{array}$ & $\begin{array}{l}\text { High DVA: } \\
\text { - Highway fencing at edge of wooded } \\
\text { area or within } 25 \mathrm{yd} \text {. }\end{array}$ \\
\hline $\begin{array}{l}\text { Reilly \& } \\
\text { Green } \\
1974\end{array}$ & $\begin{array}{l}\text { Michigan: } \\
\text { Interstate } 75 . \\
\text { White cedar deer } \\
\text { wintering area }\end{array}$ & $\begin{array}{l}\text { High DVA: } \\
\text { - Opening of new highway or highway } \\
\text { sections } \\
\text { Low DVA: } \\
\text { - Post-high local deer mortality where } \\
\text { migration routes intersected the new } \\
\text { highway }\end{array}$ \\
\hline $\begin{array}{l}\text { Bellis \& } \\
\text { Graves } \\
1971\end{array}$ & $\begin{array}{l}\text { Pennsylvania: } \\
8 \text { miles of } \\
\text { Interstate } 80 \\
\text { 4-lanes. } \\
\text { Dense deciduous } \\
\text { forest on } \\
\text { Allegheny Plateau }\end{array}$ & $\begin{array}{l}\text { Higher DVA: } \\
\text { - Elevated median and steep right-of- } \\
\text { ways form troughs that funnel deer } \\
\text { - Good grazing on median and } \\
\text { right-of-way }\end{array}$ \\
\hline $\begin{array}{l}\text { Peek \& Bellis } \\
1969\end{array}$ & $\begin{array}{l}\text { Pennsylvania: } \\
8 \text { miles of } \\
\text { Interstate } 80 . \\
4 \text { lanes-unopened. } \\
\text { Deciduous forest }\end{array}$ & $\begin{array}{l}\text { Deer crossed in highest numbers where } \\
\text { - Hills graded into valleys } \\
\text { - Adjacent to small cuts } \\
\text { Deer avoided crossing where } \\
\text { - High hills and deep valleys adjacent to } \\
\text { highway }\end{array}$ \\
\hline
\end{tabular}


This research rapidly evolved from the application of labor-intensive methodologies such as fieldwork and digitizing of maps to employment of GIS, orthophotography, satellite imagery, and other remote sensing products. This methodological evolution reduced the labor involved in data collection and preparation and facilitated analyses of larger study areas. Existing hotspot models are based on the white-tailed deer (Odocoileus virginiamus) except one (Romin and Bissonette 1996a), which focused on mule deer (Odocoileus hemionus hemionus). All but two study sites (Bashore et al. 1985, Nielsen et al. 2003) were for statewide highway networks, interstate highways, or highways through wild lands. Few published studies have examined DVA hotspots on the suburban/rural interface or on rural roads.

Currently there is no published research documenting, analyzing, or modeling DVA for the black-tailed deer (Odocoileus hemiomus columbiamus), the predominant deer subspecies west of the Cascades in Oregon, Washington, and California.

Deer-vehicle accidents are common on the outskirts of metropolitan Portland, Oregon, where Budhabhatti et al. (2002) identified 1,451 deer-vehicle accidents (DVA), based on deer carcass retrievals on county-maintained roads in northwest Clackamas County from 1997-2002. These numbers underestimate the total number of DVA by excluding incidents where deer died off the road and DVA occurring on state and federal highways or within city limits (Budhabhatti et al. 2002). Other research has shown that counts of wildlife corpses found on roads underestimate the actual road casualty rate (Slater 2002). 


\section{Black-Tailed Deer}

Black-tailed deer (Odocoileus hemionus columbianus) occupy Oregon west of the Cascades, where they proliferated in nonglaciated areas during the Pleistocene (Wallmo 1985). Historical accounts by the Lewis and Clark Expedition, however, note few deer were encountered during their exploration of northwestern Oregon, perhaps reflecting the lack of browse in the mature, pre-European forests (Verts and Carraway 1998) or hunting pressures by Native Americans (Boyd 1999). Subsequent logging, agricultural clearing, and development in northwest Clackamas County resulted in a patchy, edge-dominated landscape (Skidmore, personal communication, November 2002). Currently, the suburban-rural landscape of Clackamas County provides excellent deer habitat with ample food, water, and protective cover (Caldwell, personal communication, January 2005).

Oregon Department of Fish and Wildlife (ODFW) does not census or manage the deer population in northwest Clackamas County, but the high frequency of DVA recorded for northwest Clackamas County suggests that local deer populations are relatively large (Budhabhatti et al. 2002). Bender et al. (2004a) estimate the blacktailed deer density in rural habitats adjacent to Vancouver, Washington to be 2.7 deer $/ \mathrm{km}^{2}$. ODFW issues lethal permits to land owners in Clackamas County for emergency hunts and landowner hunts to control deer feeding damage to agricultural crops. These permits are issued year round, but most often in July (Caldwell, personal communication, January 2005). Public hunting, however, has little effect on populations because of the prolific growth of vegetation that provides excellent hiding 
and escape cover. Winter kill, which controls populations of mule deer on the east side of the Cascade Crest, is rare in the Willamette Valley because of the infrequent and short duration of snow and ice accumulation that obstructs browsing and foraging (Oregon Department of Fish and Wildlife 2005).

Hines (1975) provides one of the few published studies on the population dynamics of regional black-tailed deer. His study examined deer population change in a 340-acre (138 ha) enclosure in the northern Oregon Coast Range, where no hunting was permitted and from which predators were excluded by a barbed wire fence. Under these conditions, Hines (1975) recorded annual population increases of 42, 14, and $38 \%$ in the first three years from an original herd of 30 deer composed of 10 adult females, 5 adult males, 4 female yearlings, 3 male yearlings, 4 female fawns, and 4 male fawns.

\section{Lifestyle and Habitat Preference}

The black-tailed deer is a reclusive species west of the Cascade Crest where its behavior developed in the presence of forest cover (Bender 2000). Wallmo (1981) notes that black-tailed deer are secretive and depend on stealth and concealment rather than speed, for escape from predators. Black-tailed deer prefer the dense, early forest sere and woodland/chaparral habitats of western Oregon, where they hide in thick tangles of shrubs, vines, and small trees (Verts and Carraway 1996).

Bender et al. (2004b) investigated habitat use by the black-tail in urban Vancouver, Washington, and found deer were more frequent in forested, brushy, and 
vacant habitat, which provides a greater degree of security. Bender et al. (2004b) also determined that the primary characteristic of fawning areas was dense low cover, characterized by shrubby areas or overgrown old fields of tall herbaceous or mixed tall herbaceous/scattered shrub vegetation. In northwest Clackamas County, Caldwell (personal communication, January 2005) states that resident black-tails live in fallow areas, along river banks, and in shrub-dominated urban parks. Deer beds and scat are also common in tall grass of pastures, wetlands, nature parks, and urban greenspaces around metropolitan Portland (personal observation).

Generally crepuscular, the black-tail emerges at dusk, following woodland edges for concealment, and returning to its bed at dawn. The black-tail prefers to approach open areas such as roads under cover. The black-tail in northwest Clackamas County often moves along greenways, creeks, and rivers (Oregon Department of Fish and Wildlife 2005) similar to that reported for white-tailed deer in their movement between bedding and feeding sites along riparian conidors (Dusek et al.1998).

Black-tail graze on succulent spring grasses and browse the leafage of native plants like Pacific blackberry (Rubus ursimus) and wild roses (Rosa gymnocarpa and R. mutkana), and the dormant twigs of red alder (Alnus rubra), hazel (Corylus cormuta), and vine maple (Acer circinatum) (Verts and Carraway 1996). Black-tailed deer also consume thimbleberry (Rubus parviflorus), conifer twigs and buds, and ferns (Oregon Department of Fish and Wildlife 2005). In rural and suburban areas, deer feed on lawns, gardens, and landscape plantings (McCullough et al. 1997; Nettler, personal communication, 2005). 
Hines' 1975 study of black-tailed deer in the Cedar Creek enclosure near the northern Oregon coast reveals several additional aspects of behavior that may be relevant to deer-vehicle accidents. Black-tailed does show great fidelity to birthing sites, returning year after year. The black-tail also shows great fidelity to its home range: black-tails captured and released 8-16 km (5-10 mi) away have a remarkable ability to return to their home ranges. Even under population pressure, deer do not shift activity centers to less-preferred habitat. However, population pressures change the behavior of young bucks. Under crowding, they remain with their mother and use her range for two years, rather than dispersing and establishing their own ranges.

Grund et al. (2002) found white-tailed deer also demonstrate a high degree of fidelity to their seasonal home ranges within an urban park in Bloomington, Minnesota. Other studies of social organization and dispersal among white-tailed deer conclude that juvenile, white-tailed female deer rarely disperse, but establish home ranges on the outskirts of their mother's home range (Bumell and Harestad 1983, Porter et al. 1991). This may also be true for black-tailed females.

\section{Home Range}

Black-tail deer require year-round forage and water, shelter from inclement weather and temperatures, cover to hide from predators and persecutors including humans and domestic dogs, and safe birthing and rearing sites for their young. The size of the black-tail's home range is determined by the juxtaposition, quality, and quantity of resources. Home ranges are smaller when resources occur in sufficient 
quantities in close proximity to each other and to protective cover, and larger when resources must be obtained from a number of scattered landscape patches (Happe 1982, Turner et al. 2003, Bender et al. 2004a).

In general, black-tailed deer restrict their movement to small areas, 30-164 ha (74-405 acres) in diameter except during migration (Dasmann and Taber 1956). The black-tailed deer of urban Vancouver, Washington have annual home ranges of $\geq 162$ ha for does and $\geq 756$ ha for bucks (Bender et al. 2004b). Oregon Department of Fish and Wildlife (2005) identified many year-round resident black-tailed deer in northwest Clackamas County with home ranges usually less than 40 ha (100 acres), but as large as 243 ha (600 acres) in less favorable habitat. Miller (1970) estimated the home range of the black-tailed deer in the 138 ha (340-acre) Cedar Creek enclosure to be 31 130 ha (77-320 acres) on horizontal acreage, 52-208 ha (128-513 acres) in broken terrain. Happe (1983) estimated the annual home range of adult black-tailed does near Eugene, Oregon to be 120 ha ( 297 acres); home ranges were smallest in developed areas and largest on the fringe of developed areas.

Home range behavior is well-documented for black-tailed and white-tailed deer, but is spatially and temporally dynamic within an annual cycle. Home range may increase notably in size during spring when does return to established fawning sites, in early summer when young bucks are dispersing, and during the rutting season when bucks, including yearlings, wander extensively, seeking and pursuing does, and does evade bucks (Miller 1970, Puglisi et al. 1974, Hubbard et al. 2000). 
Daily and Seasonal Movement

In general, deer are covertly active during morning and afternoon, and bedded during the mid-day period. Deer leave cover at dusk and enter open areas to feed. During the night they alternate periods of feeding with periods of rest, returning to cover at dawn (Miller 1964, Hines 1975).

A number of events in the black-tailed deer's annual cycle influence their activity level. In February and March, deer follow the spring growth of grasses and herbs; in April and May, the renewed growth of shrubs. By June, the regional summer drought leads to the drying and dormancy of vegetation. Water becomes increasingly scarce as summer progresses, causing deer to move to areas of available food and water. This resource declines in quality and quantity until September or October when the rains resume (Dasmann and Taber 1956).

Black-tailed does return to fawning grounds in May and give birth in May and June (Dasmann and Taber 1956, Hines 1975, Bender et al. 2004a; Caldwell, personal communication, 2005). During this period, does and new fawns remain in heavy cover with ranges contracted until mid-July when they re-emerge (Dasmann and Taber 1956). In June and July, juvenile males separate from their mothers and establish their own territories; this is a period of extensive buck travel (Hines 1975). The rut, a period of extensive movement for all genders and ages of deer, extends from October to mid December (Dasmann and Taber 1956, Hines 1975; Caldwell, personal communication, 2005). The rut is followed by an abrupt drop in the activity level of 
both deer genders that continues until green-up in the spring (Dasmann and Taber 1956).

Several studies indicate that black-tailed and white-tailed deer move around extensively trying to elude hunters (Dasmann and Taber 1956, Puglisi et al. 1974). Hunting seasons begin in August and extend through February in northwest Clackamas County. These include bow hunting season (August 27-December 11), general hunting season (October 1-November 4), and Doe on Private Lands hunting season (September 1-February 28) (Caldwell, personal communication, 2005).

\section{Thesis Objectives}

While numerous studies have examined the spatial and temporal patterns of white-tailed deer-vehicle accidents (DVA), there are no studies of the spatial and temporal patterns of black-tailed deer-vehicle accidents. Only two studies have examined DVA on 2-lane roads in a mixed rural/residential/industrial landscape (Bashore et al. 1985) or suburbs (Nielsen et al. 2003), as most DVA studies involve state and federal highways and/or wild lands. No studies in the U.S. have examined deer-vehicle accidents on 2-lane county roads or on the suburban/rural interface. With the exception of the studies of Bender (2000) and Bender et al. (2004a, 2004b), there are no published studies of black-tail deer in the Portland metropolitan region.

This thesis seeks to describe the spatial and temporal patterns of DVA in the northwest Clackamas County portion of Metropolitan Portland to provide a better understanding of DVA near the suburban/rural fringe and provide knowledge needed 
to support DVA mitigation decisions and public education. I do so by addressing the following research directives:

- Identify the daily, weekly, seasonal, and annual DVA cycle

- Relate daily DVA cycle to sunrise, sunset, morning rush hour, and evening rush hour

- Relate daily and seasonal DVA cycles to black-tailed deer daily and seasonal cycles

- Identify DVA hotspots in northwest Clackamas County

- Determine percentage of DVA that occur within hotspots and outside of hotspots

- Examine the seasonal shifts of DVA hotspot locations

- Relate the literature-described landscape, road, and traffic characteristics of DVA hotspots to selected Clackamas County DVA hotspots

These objectives are consistent with the current goals of Metro Parks and Greenspaces to identify and restore wildlife movement corridors within the Metro area in order to implement its mission of protecting the region's wildlife biodiversity. The Transportation Equity Act for the 21st Century (TEA-21) provides funding to construct wildlife overpasses and underpasses at locations where wildlife movement corridors intersect roads (Eraut, personal communication, April 2005). Determining where these intersections occur and produce DVA hotspots is critical for effective placement of crossing structures. DVA hotspot locations can be determined through collaring and monitoring of deer movement or, less expensively, by identifying DVA hotspots through carcass pickup reports and deer-vehicle accident reports. 
Public education is another form of mitigation for deer-vehicle accident hotspots (Finder et al. 1999, Hindelang et al.1999, British Columbia Conservation Foundation 2005). If the temporal pattern of DVA can be determined and DVA hotspots identified in the Portland metropolitan region, public service announcements and signage can warn the public to exercise caution and reduce vehicle speed during those hours and seasons, and in those places, where deer are most actively crossing roads. Education and reduced speed limits are the least expensive forms of DVA mitigation. 


\section{CHAPTER 2}

\section{STUDY AREA}

My study area is located in northwestern Clackamas County, Oregon (Figure 1). It includes approximately $900 \mathrm{mi}^{2}\left(2,331 \mathrm{~km}^{2}\right)$, or approximately one-half the area of Clackamas County $\left(1,879 \mathrm{mi}^{2}\right)$. The study area incorporates portions of southeastern urban Portland and a number of smaller, incorporated cities (Table 2), including a large portion of the Portland metropolitan suburban/rural fringe. I selected northwest Clackamas County for this study because the Clackamas County

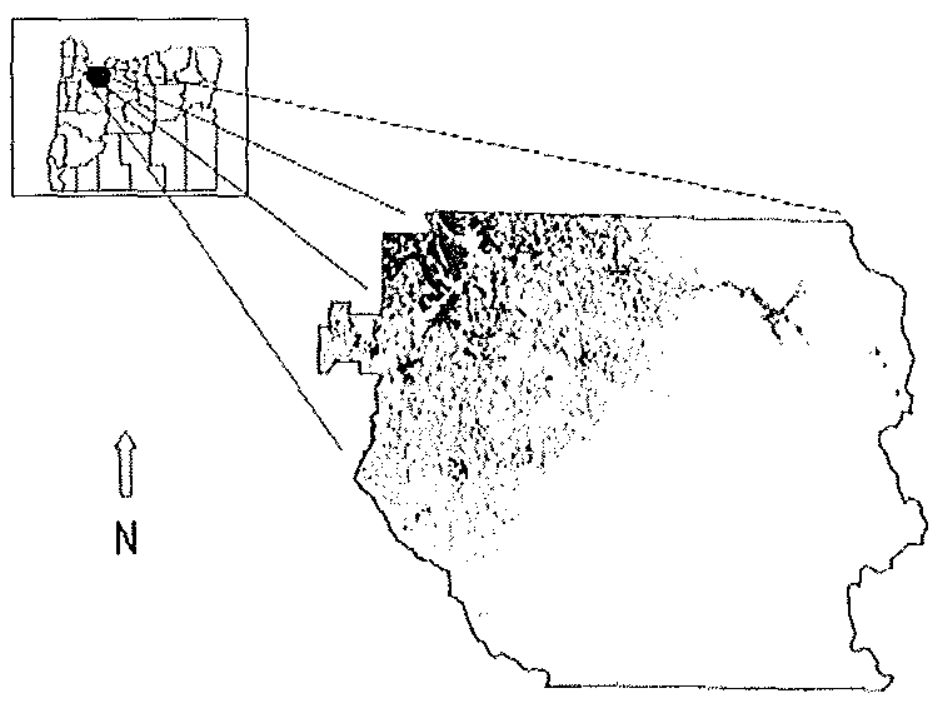

Figure 1. Location of study area (shaded) in northwestern Clackamas County. Based on population by census tract delineation (2000 Census). Source: Clackamas County GIS Division 2005. 
Road Department has maintained computerized records of deer carcass pickups on county-maintained roads for the past eight years, and because growth in northwestern Clackamas County is characteristic of growth on the perimeter of many urban areas coinciding with the biogeographic range of black-tailed deer.

Table 2. Incorporated cities fully or partially located within study area in northwest Clackamas County. Source: Oregon Bluebook 2005.

$\begin{array}{ll}\text { Barlow } & \text { Milwaukie } \\ \text { Canby } & \text { Molalla } \\ \text { Damascus } & \text { Oregon City } \\ \text { Estacada } & \text { Portland } \\ \text { Rivergrove } & \text { Gladstone } \\ \text { Sandy } & \text { Happy Valley } \\ \text { Tualatin } & \text { Johnson City } \\ \text { West Linn } & \text { Lake Oswego } \\ & \text { Wilsonville }\end{array}$

The rural portion of the study area consists of a matrix of cultivated and abandoned farm fields, orchards, commuter estates, home businesses, scattered suburban development, and wild habitat. Approximately one-eighth of Clackamas County's land area is urban; the majority is rural. Some of Oregon's richest farmland lies within the study area around the cities of Canby, Sandy, Boring, Wilsonville, and Molalla. (Clackamas County Overview 2005). The eastern one-half and southwestern one-quarter of Clackamas County are predominantly public lands. The study area is bounded on the east by the Mount Hood National Forest. It is bounded on the south by sparsely populated private land and land managed by the Bureau of Land 
Management (BLM). Smaller parcels, usually parks, green spaces, and wild lands belonging to the U. S. Forest Service, B.L.M., Clackamas County, Metro Regional Government, the Oregon Department of Forestry, and Oregon State Parks are dispersed throughout the study area.

The study area is laced with riparian corridors and includes portions of five major drainage basins associated with the Tualatin River, Willamette River, Sandy River, Clackamas River, and Molalla River. The eastern portion of the study area is close to sea level and lies in the Willamette Valley, a broad alluvial plain interspersed with low, basalt hills. The western portion of the study area begins a gentle ascent into the foothills of the Western Cascades to an altitude of $455 \mathrm{~m}(1500 \mathrm{ft})$.

The regional climate is characterized by cool, wet periods between October and May, and a warm summer drought beginning in late June through September. Mean annual temperature is $5.4^{\circ} \mathrm{C}\left(41.8^{\circ} \mathrm{F}\right)$ in January and $20.7^{\circ} \mathrm{C}\left(69.3^{\circ} \mathrm{F}\right)$ in July (Oregon Climate Service 2005). Rainfall ranges from $102-127 \mathrm{~cm}(40-50 \mathrm{in})$ in the western portion of the study area to $152-178 \mathrm{~cm}(60-70 \mathrm{in})$ in the eastern portion with $90 \%$ of the total precipitation occurring from October to June (National Oceanic and Atmospheric Administration 2006).

Vegetation of the Willamette Valley and the study area has been extensively altered by human activities and currently includes many domestic and invasive plant species. Traditional vegetation of the Willamette Valley was Oregon oak savannah (Quercus garryana), but little remains (Johannessen et al. 1971). Stream-side vegetation includes big leaf maple (Acer macrophyllus), red alder (Almus rubra), black cottonwood (Populus trichocarpa), and willow (Salix spp.). The dominant plant 
community in the foothill area includes Douglas-fir (Pseudotsuga menziesii), occasional western red cedar (Thuja plicata), western hemlock (Tsuga heterophylla), and Oregon oak.

The population of Clackamas County increased 10.6\% between 1996-2004, from 322,160 persons in 1996 to 356,250 persons in 2004 (Table 3).

Table 3. Census population and inter-censal population estimates for Clackamas County, July 1, 1996-2004. Source: Oregon Population Report (Population Research Center 2004).

$\begin{array}{ll}\text { Year } & \text { Population } \\ 1996 & 322,160 \\ 1997 & 328,680 \\ 1998 & 332,830 \\ 1999 & 336,050 \\ 2000 \text { (census) } & 338,391 \\ 2001 & 345.150 \\ 2002 & 350,850 \\ 2003 & 353,450 \\ 2004 & 356,250\end{array}$

Population in Clackamas County increased $26.8 \%$ from 1990-2003, with some cities, including Wilsonville, Tualatin, and Oregon City, experiencing 100\% increases.

Population in unincorporated areas, including unincorporated urban areas, increased $13.7 \%$ (Appendix A). Most of this population is concentrated within the study area 
(Figure 1). New building permits for all private residential buildings, single and multi-unit, in Clackamas County dropped from 1,774 buildings in 2000 to 1,569 buildings in 2002, and increased to 2,021 by October, 2005 (Table 4).

Table 4. Annual building permits for new, privately-owned residential buildings in Clackamas County, 2000-2004. Includes single- and multi-unit buildings. Source: U.S. Census Bureau 2004.

$\begin{array}{ccc}\text { Year } & \text { Buildings } & \text { Units } \\ 2000 & 1,774 & 2,253 \\ 2001 & 1,737 & 1,969 \\ 2002 & 1,569 & 1,806 \\ 2003 & 1,615 & 1,712 \\ 2004 & 1,978 & 2,165\end{array}$

The economy of Clackamas County is based on agriculture, metal manufacturing, machinery, healthcare, high-tech, logistics, forestry, food and beverage processing, renewable energy, tourism, software development, trucking and warehousing, nursery stock, retail services, wholesale trade and construction (Oregon Blue Book of Clackamas County 2005). Fifty percent of County residents commute to employment outside of the County (Carpenter, personal communication, 2005). Mean travel time to work is estimated at 26.2 minutes (City-data 2005). Average daily miles traveled increased in Clackamas County from ten miles in 1995 to fifteen miles in 2005 (Weinman, personal communication, November 2005) . Carpenter (personal 
communication, November 2005) estimates the County average daily miles traveled as ten miles/day/private residence and five-seven miles/day/apartment residence.

Vehicle miles traveled on state-owned highways within Clackamas County increased 11.2\%, from 1.5674 billion miles in 1996 to 1.7426 billion miles in 2004 (Table 5) and provide a reasonable estimate for vehicle miles traveled on county- and city" owned roads because they exchange vehicles (Marek, personal communication, November 2005).

Table 5. Vehicle miles traveled (VMT) on state-owned highways within Clackamas County, 1996-2004. VMT are rounded to nearest 100,000 miles and expressed in billions of miles. Source: Oregon Department of Transportation 2005.

\begin{tabular}{cc} 
Year & $\begin{array}{c}\text { Vehicle Miles } \\
\text { Traveled } \\
\text { (billions of miles) }\end{array}$ \\
\hline $\mathbf{1 9 9 6}$ & 1.5674 \\
$\mathbf{1 9 9 7}$ & 1.6317 \\
$\mathbf{1 9 9 8}$ & 1.6447 \\
$\mathbf{1 9 9 9}$ & 1.6804 \\
$\mathbf{2 0 0 0}$ & 1.7213 \\
$\mathbf{2 0 0 1}$ & 1.7208 \\
$\mathbf{2 0 0 2}$ & 1.7600 \\
$\mathbf{2 0 0 3}$ & 1.7620 \\
$\mathbf{2 0 0 4}$ & 1.7426
\end{tabular}


Zoning in rural Clackamas County outside the urban growth boundary requires a minimum lot size of 2 acres. The large minimum lot size and increasing number of ranchettes and commuter estates have contributed to rapid development of rural land and increased the patchiness of the local landscape (Skidmore, personal communication, November 2002). Lot size has also contributed to high automobile dependency among local residents by increasing the distance from home to work, school, and stores.

Well-maintained, two-lane county roads carrying heavy commuter traffic moving at $88-96 \mathrm{kmh}(55-60 \mathrm{mph})$ lace this landscape, penetrating wood lots, traversing forest-field edges, and frequently intersecting riparian corridors. Miles of county-owned roads and the state highway system remained constant between 19982004 , but miles of city-owned roads increased $12.3 \%$ during that period, from 649 miles in 1998 to 729 miles in 2004 (Table 6).

Table 6. Clackamas County road mileage for county rural roads, county municipal extensions, county local access, state highway system, and roads owned by cities. Source: Oregon Mileage Reports, 1998-2004.

\begin{tabular}{llllll} 
Year & $\begin{array}{l}\text { County } \\
\text { Rural } \\
\text { Roads }\end{array}$ & $\begin{array}{l}\text { County } \\
\text { Municipal } \\
\text { Extension }\end{array}$ & $\begin{array}{l}\text { Local } \\
\text { Access }\end{array}$ & $\begin{array}{l}\text { State } \\
\text { Highway } \\
\text { System }\end{array}$ & $\begin{array}{l}\text { City } \\
\text { Owned }\end{array}$ \\
\hline $\mathbf{1 9 9 8}$ & 1,407 & 27 & 108 & 222 & 649 \\
$\mathbf{1 9 9 9}$ & 1,407 & 27 & 108 & 222 & 687 \\
$\mathbf{2 0 0 0}$ & 1,407 & 27 & 108 & 222 & 701 \\
$\mathbf{2 0 0 1}$ & 1,407 & 27 & 108 & 222 & 736 \\
$\mathbf{2 0 0 2}$ & 1,407 & 27 & 108 & 222 & 756 \\
$\mathbf{2 0 0 3}$ & 1,401 & 23 & 108 & 222 & 740 \\
$\mathbf{2 0 0 4}$ & 1,334 & 88 & 108 & 222 & 729
\end{tabular}


Registered vehicles in Clackamas County increased $43 \%$ in ten years, from 276,522 vehicles in 1996 to 394,087 vehicles in 2004 (Figure 2, Table 7). Registered drivers in the County was 290,675 in 1997 , decreased and rose slowly to 291,079 in 2003, a net increase of $0.13 \%$. The number of registered vehicles exceeded the number of registered drivers by $34 \%$ in 2004 .

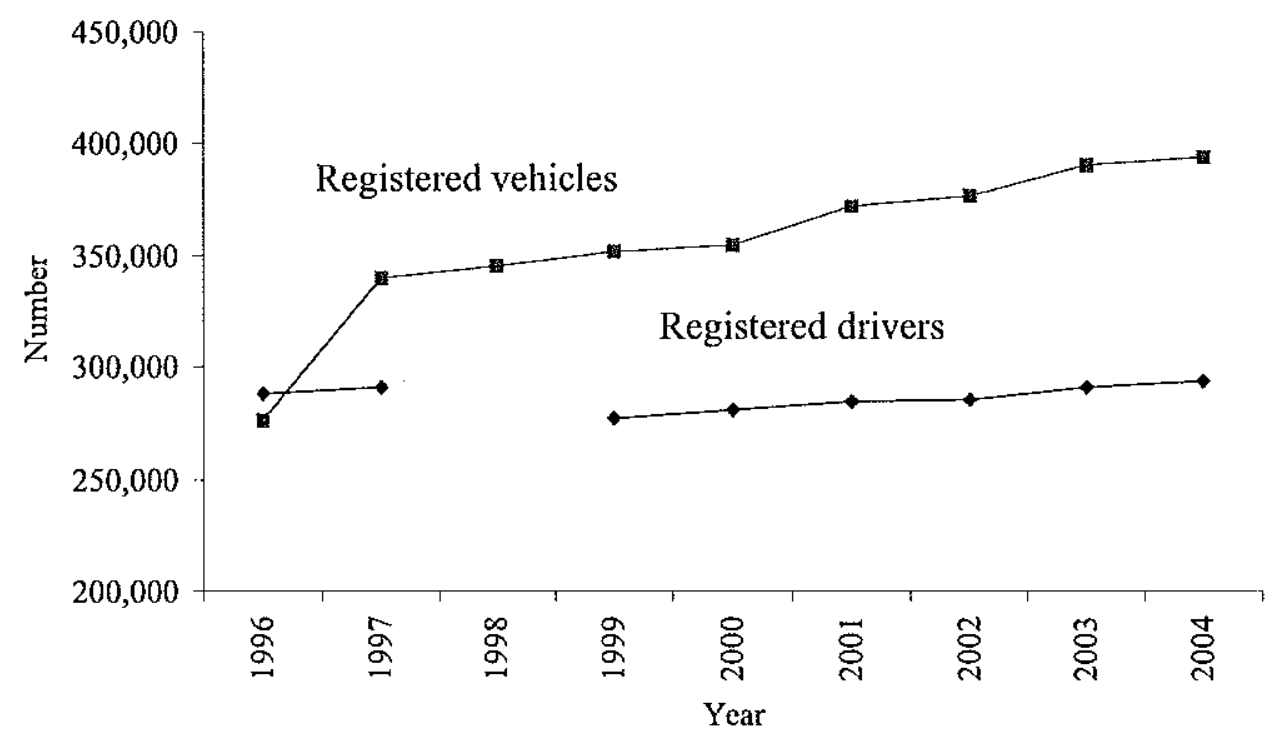

Figure 2. Registered vehicles and registered drivers in Clackamas County, 1996-2004. Source: Oregon Department of Transportation 2004. No data is available for registered drivers in 1998. 
Table 7. Number of registered drivers and number of registered vehicles in Clackamas County, 1996-2004. N/A: No data is available for registered drivers in 1998. Source: Oregon Department of Transportation 2004.

\begin{tabular}{lll} 
Year & $\begin{array}{c}\text { Registered } \\
\text { Drivers }\end{array}$ & $\begin{array}{c}\text { Registered } \\
\text { Vehicles }\end{array}$ \\
\hline 1996 & 288,082 & 276,522 \\
1997 & 290,675 & 340,065 \\
1998 & N/A & 345,161 \\
1999 & 277,107 & 351,752 \\
2000 & 280,986 & 354,035 \\
2001 & 284,507 & 371,623 \\
2002 & 285,482 & 376,744 \\
2003 & 291,079 & 390,349 \\
2004 & 293,770 & 394,087
\end{tabular}




\section{CHAPTER 3}

\section{METHODS}

\section{Data Sources}

Data for this research was derived from two sources, deer carcass pickup reports on roads maintained by Clackamas County from 1997-2004 and Oregon Department of Transportation (ODOT) deer-vehicle accident reports for 1996-2004. Carcass pickup reports provided locations of deer-vehicle accidents (DVA). Deervehicle accident reports provided time-of-day and day-of-week of DVA.

\section{Deer Carcass Pickup Reports}

Clackamas County Road Department picks up deer carcasses and records the pickup location on 1,421 miles of County-maintained roads--335 miles in urban areas and 1,086 miles in rural areas (Clackamas County Transportation Maintenance 2005b). I used deer carcass pickup reports (Dead Animal Requests) to identify DVA temporal patterns and hotspots and to track seasonal shifts in hotspot locations between January 1997 and December 2004. During this period, Clackamas County Road Department recorded 1,880 deer carcass pickups (Clackamas County Transportation Maintenance 2005a). These data represent pickups from roads or road shoulders of whole deer carcasses resulting from deer-vehicle accidents. Carcass 
pickup reports include location, date of pickup, and species. Metro Regional Government's Data Resource Center geocoded DVA locations representing January 1 , 1997 to August 7,2002. I geocoded or digitized DVA locations, depending on the location description, representing August 8, 2002 to December 31, 2004, as part of this research.

Data Precision. I sought to achieve a mapped locational precision of $\leq 0.25$ mi for each DVA and recorded the difference between the actual and the geocoded or digitized DVA location. Several potential sources of imprecision existed in the DVA location mapping process. Carcass locations were dispatcher-described as: 1) near a house or landmark with a specific address, 2) a distance from an intersection or other landmark, or 3) located between two intersections. Geocoding assigns x, y coordinates in a projected coordinate system based on a given address (Ormsby et al. 2004). When an address was unavailable or unassignable, locations for DVA occurring between January 1, 1997 and August 7, 2002 were assigned to the intersection or nearest road and the distance from the assigned location and the dispatcher-described location recorded as the precision.

Digitizing assigns $\mathrm{x}, \mathrm{y}$ coordinates in a projected coordinate system directly (Ormsby et al. 2004). DVA between August 8, 2002 and December 31, 2004 described as occurring between two intersections were digitized at the midpoint between the two intersections, with precision defined as one-half the distance between the intersections. A second source of imprecision $(\approx 10 \%)$ occurs during the geocoding process, which maps an address based on interpolation of its location 
between the two end points of the street on which it occurs (Price, personal conversation, 2002).

Eighty-nine percent of the locations occurred within $0.25 \mathrm{mi}$ of where they are geocoded or digitized; the remaining $11 \%$ have an imprecision $>0.25 \mathrm{mi}$ or an unknown imprecision (Table 8). DVA locations occurring on roads through rural or wild areas with few cross streets tend to be less accurate than DVA locations occurring closer to the suburban/rural interface where there are more house addresses and intersecting roads for describing DVA locations more precisely. Most hotspots are in the latter locations.

Table 8. Mapping accuracy of DVA locations. Source: Deer carcass pickup reports, Clackamas County, 1997-2004.

\begin{tabular}{|c|c|c|c|}
\hline & & $\begin{array}{c}\text { \# of DVA } \\
\text { with Imprecision } \\
\text { Unknown }\end{array}$ & $\begin{array}{c}\text { Percentage } \\
\text { with Imprecision } \\
\text { Unknown }\end{array}$ \\
\hline ata Period & \# of DVA & or $\geq .25 \mathrm{mi}$. & or $\geq .25 \mathrm{mi}$. \\
\hline
\end{tabular}

Jan. 1, 1997-Aug. 7, 2002

1310

132

10.0

August 8, 2002-Dec. 31, 2004

570

72

12.6

Total

1880

204

10.9

I assigned each DVA location $\mathrm{x}, \mathrm{y}$ coordinates in the projected coordinate system, Oregon State Plane North (NAD 1983). Then I mapped these locations by layering the shape file of deer carcass pickup locations with the RLIS-Lite files 
Stm-line (streams and rivers), Streets, and County boundaries, and clipping the final map to the Clackamas County boundary.

\section{Deer-Vehicle Accident Reports}

I used ODOT deer-vehicle accident reports (DVAR) for 1996-2004 to identify hourly DVA patterns and examine the correspondence between DVA peaks, dawn and dusk, and morning and evening rush hour. These reports provide time-of-day of accident, and are filed for any DVA occurring on a federal, state, county, or city transportation network that causes at least $\$ 1000$ in vehicle damage or injures or kills a vehicle occupant. ODOT does not maintain records for the deer carcasses it removes from state and federal highways; consequently, knowledge of DVA on these highways is limited to deer-vehicle accident reports.

ODOT compiled 715 deer vehicle accident reports for deer-vehicle crashes between January 1, 1996 and December 31, 2004 in Clackamas (397), Washington (224), and Multnomah (94) Counties (Oregon Department of Transportation 19962004). These reports contain accident location, date, time, day-of-week, and wildlife species. ODOT records the time of a deer-vehicle crash rounded to the nearest hour according to the clock regime in effect, i.e., Pacific Standard Time or Pacific Daylight Savings Time. I converted all crash times to Pacific Standard Time. Potential sources of inaccuracy in deer-vehicle accident reports include the driver's description of the accident location and the ODOT employee's attempt to assign an address to it. 


\section{Sunrise and Sunset}

I tested the hypothesis that DVA increase at dawn and during the period, dusk +2 hours, by comparing these periods to other daylight hours. I defined dawn as the period between nautical twilight and sunrise, and dusk as the period between sunset and nautical twilight. General outlines of ground objects may be distinguishable and the horizon is indistinct during nautical twilight, under good atmospheric conditions and in the absence of other illumination. Nautical twilight occurs in the morning and in the evening when the center of the sun is geometrically $12^{\circ}$ below the horizon (U. S. Naval Observatory 1996). Sunrise and sunset occur for an observer at sea level with a level, unobstructed horizon, under average atmospheric conditions, when the upper limb of the Sun appears to be tangent to the horizon (U. S. Naval Observatory 1996). Objects are more visible at sunrise and sunset than during nautical twilight.

I obtained times-of-day for morning and evening nautical twilight, sumrise, and sunset from the U:S. Naval Observatory's Astronomical Applications Department. I used times-of-day in Pacific Standard Time for all days of the year 1996. Nautical twilight, sunrise, and sunset for a particular day of the year fluctuated only a few minutes between 1996 and 2004 (U. S. Naval Observatory 1996).

I used the earliest nautical twilight and the latest sunrise times to represent dawn, and the earliest sunset and latest nautical twilight time to represent dusk for each month. This procedure resulted in the dawn periods ranging from 85-124 minutes, and the dusk periods ranging from $80-126$ minutes $(\approx 1.5-2.0$ hours $)$. I 
collapsed these time periods to hours to match ODOT's hourly deer-vehicle accident reporting procedure. I also rounded crash hours with $\leq 5$ minutes, e.g., 8:05 to 8:00 (Appendix B).

I defined dawn and dusk as the periods between nautical twilight, sunrise, and sunset rather than relying solely on sunrise and sunset because black-tailed deer are generally shy, crepuscular animals who avoid being seen by humans. Sunrise at $45^{\circ}$ $\mathrm{N}$ latitude occurs more than one hour after a.m. nautical twilight. Sunset occurs at least one hour before p.m. nautical twilight. At sunrise and sunset, deer would be visible, so unlikely to cross roads at these times, as suggested by the daily pattern of DVA. Because deer conduct most of their activities in the dark, they would, hypothetically, be attuned to small changes in light that suggest the approach of darkness or dawn. If so, they would be more likely to leave cover to feed around p.m. nautical twilight and return to cover from feeding at or before a.m. nautical twilight when they could see but not be seen.

\section{Traffic Counter Studies}

I used Traffic Counter Studies from the Traffic Engineering Section, Clackamas County Transportation and Development, for 1997 and 2002, to compare the percentage of truck traffic, traffic volume, and vehicle speed among DVA hotspots. Traffic Counter Studies summarize the information obtained from traffic counter stations located on Clackamas County Roads. They provide the following information relevant to this study: 
- Road name and mile point (MP) of the counter location

- Average Daily Traffic (ADT), which is annual average daily traffic

- Combined Average Daily Traffic (ADT) for a particular year, which is the combined ADT for traffic moving in opposite lanes, e.g., east- and west-bound under

- 85 th Percentile Speed, which is the speed under or equal to which $85 \%$ of the vehicles passing the counter travel

- Truck Axel Factor, which is the percentage of all vehicles passing that are trucks. Average Truck Axel Factor $=0.89($ Carpenter 2005)

All traffic counters are present on the same road and within several miles of the DVA hotspots. I used traffic counts for 1997 and 2002 to bracket the study period. Traffic volumes are monitored at designated stations every three years and exhibit little yearto-year variation (Marek, personal conversation, November 2005).

\section{Morning and Evening Rush Hour}

I used time-of-day for morning and evening rush hour to test the hypothesis that a greater number of DVA occur when periods of peak traffic volume occur at dawn and dusk +2 hours, the periods when deer are most actively crossing roads. ODOT does not officially define morning and evening rush hours (Davis, personal communication, July 2005). However, 7-9 am and 4-6 pm on weekdays are a reasonable estimate of weekday morning and evening rush hours in the Portland metropolitan region with actual times varying by location (Crownover, personal 
communication, August 2005). Ron Weinman (personal communication, November 2005) suggests that 7..9 am and 4:30-6:30 pm with a subpeak at 11:30 am12:30 pm are reasonable estimates of rush hour.

Congestion frequency on I-205, the primary freeway/expressway servicing Clackamas County, for October 2005, exceeded 50\% from 6:30-8:30 a.m. and from 4:00-6:00 p.m. (Table 9, Appendix C). Average traffic volume for Redland Road, a major arterial, peaked from 5:00-8:00 a.m. and from 3:00-5:00 pm on June 27-30, 2005 (Figure 3). Average traffic volume for Beavercreek Road, minor arterial, October 3-6, 2005, peaked from 6:00-8:00 a.m. and from 4:00-6:00 p.m. (Figure 3). I used data for June and October because DVA peak in these months. ODOT deervehicle accident reports, which I used to determine DVA time-of-day, include accidents from all classes of highway/road in Clackamas County. Consequently, I used the high traffic volume periods, 6:00-9:00 a.m. and 4:00-7:00 p.m. as rush hour periods to capture the varying peaks from freeway, major arterials, and minor arterials (Table 9).

Table 9. Morning (a.m.) and evening (p.m.) traffic volume peaks for I-205 ${ }^{1}$, Redland Road $^{2}$, and Beavercreek Road ${ }^{2}$. Sources: Portland Oregon Regional Transportation Archive List $2005^{1}$ and Traffic Counter Studies, $2005^{2}$.

Road

I-205

Redland Rd.

Beavercreek Rd. $\quad 6: 00-8: 00$
P.M. Peak

$4: 30-5: 30$

$3: 00-5: 00$

4:00-6:00 


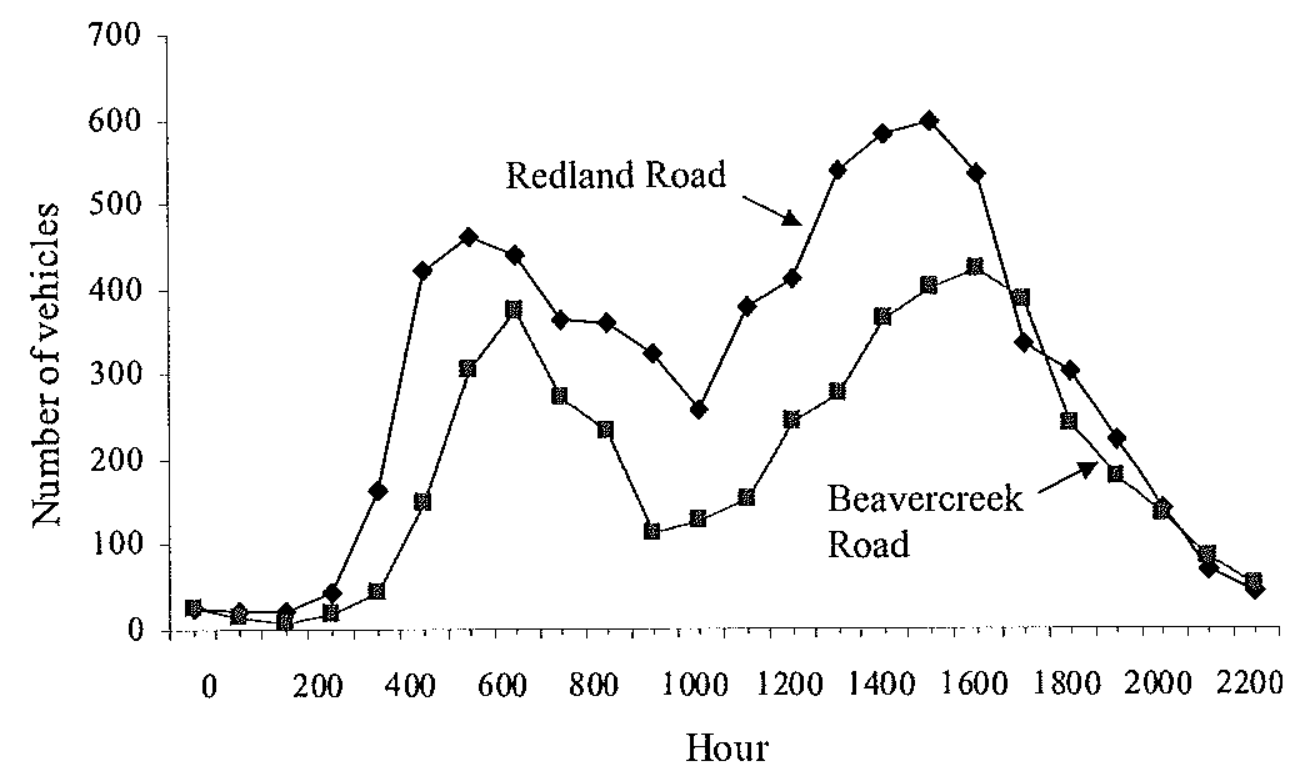

Figure 3. Average traffic volume on Redland Road (7,040 vehicles/day) on 6/2730/05 (M-Th) and on Beavercreek Road (4,602 vehicles/day) on 10/03-05/05 (M-W). Source: Traffic Counter Studies for Redland Road, West of Norman Road, 06/27/05 and Beavercreek Road, at M.P. 10.70, 10/04/05.

\section{Monthly Traffic Count Factors}

I used the 2005 Monthly Traffic Count Factors from the Traffic Engineering Section, Clackamas County Transportation and Development, to determine traffic volume for January 1997 and 2002, and November 1997 and 2002. The Monthly Traffic Count Factors are calculated from ODOT permanent traffic counter location recordings and include an urban and a rural factor for each month (Appendix G). These factors are used to convert the raw average daily traffic total for a particular 
month to the anmual Average Daily Traffic (ADT). Carpenter (personal

communication, November 2005) states that monthly traffic volume factors have changed little since 1997. Traffic volume fluctuates in a predictable fashion from month-to-month on both ODOT maintained highways and County roads, which share and exchange traffic.

\section{Defining Deer-Vehicle Accident Hotspots}

\section{Literature Definitions of DVA Hotspots}

DVA hotspots have been defined using a range of criteria including number of incidents/location, number of incidents/distance, and number of incidents/time period

Table 10. Defining criteria of DVA hotspots in studies developing DVA hotspot models for white-tailed and mule deer.

\begin{tabular}{lcc}
\multicolumn{1}{c}{ \# of DVA } & Time Period & Study Source \\
\hline & & \\
$\geq 15$ incidents/location & $1989-1993$ (4 years) & Finder et al. 1999 \\
$\begin{array}{l}\geq 4 \text { incidents in previous } \\
\text { year, } \geq 2 \text { in last } 5 / 10 \text { years }\end{array}$ & $1969-1982(13$ years $)$ & Bashore et al. 1985 \\
$\geq 2$ incidents $/$ location & $1993-2000(7$ years $)$ & Nielsen et al. 2003 \\
$\geq 14$ incidents $/ 1.61 \mathrm{~km}$ & $1990-1997(7$ years $)$ & Hubbard et al. 2000 \\
$\geq 8$ incidents $/ \mathrm{km}$ & $1991-1993(2$ years $)$ & Romin \& Bissonette $1996 \mathrm{a}$
\end{tabular}


(Table 10). Romin and Bissonette (1996) considered a road segment a hotspot if $\geq 8$ kills occurred per km within a 2-year period, and that the hotspot continued until no DVA occurred for $0.16 \mathrm{~km}$, based on a DVA location accuracy of $0.16 \mathrm{~km}$. Bashore et al. (1985) considered a road segment a hotspot if $\geq 4$ kills occurred in the previous year and $\geq 2$ kills in each out of 5 of the 10 years prior, with no mention of the criterion that signals the boundaries of the hotspot. Nielsen et al. (2003) considered a road segment a hotspot if $\geq 2$ kills had occurred at the same location within a 7-year period. Finder et al. (1999) considered a road segment a hotspot if $\geq 15$ kills had occurred at a location within a 4-year period. Hubbard et al. (2000) considered a road segment a hotspot if $\geq 14$ kills occurred within $1.61 \mathrm{~km}$ in 7 years.

\section{Analytical Methods}

\section{Spatial and Temporal DVA Patterns}

\section{Annual and Seasonal DVA Patterns}

I used 1997-2004 carcass pickup reports for Clackamas County to identify annual and seasonal DVA patterns on county-maintained roads. I sorted pickup report dates by year and by month to identify number of DVA occurring in each of the eight years and in each month of those years. I then graphed the annual and monthly data to 
reveal the patterns. Using the 1996-2004 ODOT deer-vehicle accident reports (DVAR), I identified seasonal DVA patterns on all public roads in Clackamas, Washington, and Multnomah Counties. For each county, I sorted accident dates by month for all nine years combined to identify number of DVA occurring in each month of those years and graphed the monthly data by individual county and all counties combined to reveal seasonal patterns.

Based on the literature describing black-tailed and white-tailed deer seasonal activity, I developed a timeline for activities, including winter reclusion, doe movement to fawning sites, fawning and seclusion of fawn, young male establishment of own territory, re-emergence of doe with fawn, rut season, and hunt season. I laid this timeline over the graphed seasonal DVA pattern to identify correspondence between deer activity and deer-vehicle accidents.

I calculated the percentage of DVA occurring during the three rut/hunt months of September, October, and November, and the percentage of DVA occurring during the nonrut/nonhunt months of December-August, using Clackamas County carcass pickup reports for 1997-2004. I sorted the reports by month of carcass pickup for all years combined, combined monthly DVA totals for the appropriate months, depending on the objective (total rut/hunt or nomrut/nonhunt DVA), divided that total by total DVA for the eight years combined, and multiplied by 100 to calculate percentage. 
Day-of-Week DVA Pattern

I used 1996-2004 ODOT deer-vehicle accident reports to examine the day-ofweek DVA pattern. For Clackamas County, I sorted and graphed DVAR by day of week for each month of the year and all years combined I reduced the number of elements by creating combinations of months corresponding to a 3-month deer seasonal cycle, a 4-month deer seasonal cycle, and a 3-month climate season (Table 11), and graphed and examined these patterns. In all instances, I graphed the percentage that the number of DVA for each day-of-the week represented of the total monthly DVA, in order to equilibrate the wide range of difference in DVA numbers for particular months, (i.e., DVA\% = Day DVA/Total Month DVA).

I also sorted DVAR for Clackamas, Washington, and Multnomah Counties by day-of-week for all months and all years combined and calculated the percentage that each day-of-the-week's DVA represented of total DVA for all days-of-the-week. I then graphed and examined these patterns for individual counties and all counties combined. 
Table 11. Months of year in 3- and 4-month deer seasonal cycles and climate season.

Pattern \# of Months Month Clusters in Pattern

Deer seasonal cycle

Climate season
3

3

\author{
Dec.-Feb. \\ Mar.-May \\ June-Aug. \\ Sept.-Nov. \\ Dec.-Mar. \\ Apr.-July \\ Aug.-Nov. \\ Jan.-Mar. (winter) \\ Apr.-June (spring) \\ July-Sept. (summer) \\ Oct.-Dec. (fall)
}

\section{Daily DVA Pattern}

Using deer-vehicle accident reports (DVAR), I identified the daily (24-hour clock) DVA pattern. I sorted DVAR for Clackamas, Washington, and Multnomah counties by month and hour-of-day for all years combined, and by hour-of-day for all months and years combined, and graphed and examined these patterns. Then I determined the correspondence between DVA hour-of-day for Clackamas County, dawn, dusk +2 hours, morning rush hour, and evening rush hour by creating a table of DVA sorted by month and hour-of-day, overlaid by bands of color and texture for 
hours of dawn, dusk +2 hours, morning rush hour, and evening rush hour. I then quantified the temporal correspondence.

\section{Deer-Vehicle Accident Hotspots}

I identified DVA hotspots using CrimeStat III (Levine 2004), a spatial statistics package developed to analyze incident location data. CrimeStat III is a stand-alone Windows-based program that can graphically interface with desktop geographic information systems (GIS). Results can be saved as ArcView shape (.shp) and data base format (.dbf) files and displayed in GIS ArcMap. CrimeStat also ranks hotspots in order of density (Levine 2004). I used three CrimeStat III routines in my hotspot delineations: 1) fuzzy mode, 2) nearest neighbor clustering, and 3) mode to identify and quantify hotspots from deer carcass pickup reports.

\section{Defining Clackamas County DVA Hotspots}

All literature definitions of hotspots include the components, "number of kills" and "period of time" (Table 11). Several include the component "distance." I determined "number of kills," i.e., minimum hotspot size (DVA) for examination, using the CrimeStat III fuzzy mode routine (Levine 2004). CrimeStat's fuzzy mode identifies DVA densities on roads within the study area by determining the frequency of other DVA within a user-specified search radius of each DVA. I used a $0.5 \mathrm{mi}$ search radius. 
I identified natural breaks in the distribution of DVA frequencies using a frequency diagram to reveal any underlying empirical organization or the presence of constraining features in the data set (Figure 4, Appendix D). This diagram revealed three distinct DVA groupings based on a $0.5 \mathrm{mi}$ search radius: 942 DVA (63\% of total DVA) occurring with 1-7 other DVA, 429 DVA (29\% of total DVA) occurring with $8-15$ other DVA, and 129 DVA (9\% of total DVA) occurring with 16-27 other DVA (Figure 4). I selected the latter category, 16-27 other DVA/hotspot, for further examination. The time frame of my DVA location data includes the eight years between 1997-2004 and falls within the time frames of other DVA studies (range: 213 years).

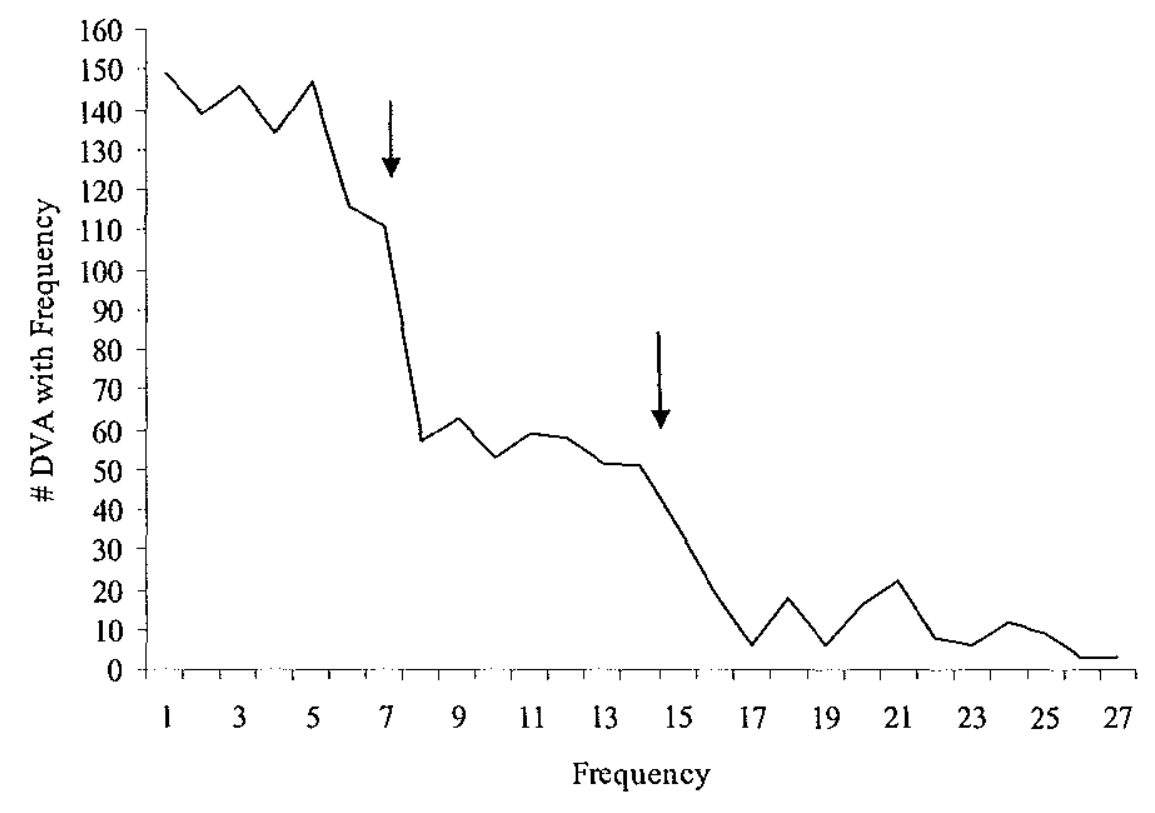

Figure 4. Three frequency classes (cutoffs indicated by arrows) of other DVA within $0.5 \mathrm{mi}$ search radius of every DVA, for Clackamas County, 1997-2004. 
Identifying the spatial extent of hotspots. I identified hotspots using the nearest neighbor routine in Crimestat III (Levine 2004). Nearest neighbor clustering is an inferential technique with two options. One establishes a one-tailed confidence interval around the random expected nearest neighbor distance. The confidence interval (threshold distance) defines a probability for the distance between any pair of points. For example, for a one-tailed probability of $5 \%$, fewer than $5 \%$ of the incidents would have nearest neighbor distances smaller than this interval if the distribution is spatially random.

I analyzed my DVA data using a 5\% probability of including random DVA in my hotspot clusters and a minimum cluster size of 10 DVA. This routine provides a graphic output by placing an ellipse around each cluster. I added any additional DVA that lie within $0.33 \mathrm{mi}(0.53 \mathrm{~km})$ of the outlying DVA at either end of the cluster. This adjustment was made to accommodate any positional imprecision in my DVA locations ( $\leq 0.33 \mathrm{mi}$ or $0.53 \mathrm{~km}$ ). This technique also establishes the hotspot endpoints. Each hotspot identified through this procedure has a different length.

I used the second option of the nearest neighbor statistical clustering routine to confirm DVA locations and explore the dispersion of DVA along roads, using search radii of $0.125 \mathrm{mi}, 0.25 \mathrm{mi}$, and $0.5 \mathrm{mi}$ with a minimum cluster size of 10 DVA. This option is less conservative than the inferential option with the $5 \%$ probability and includes more DVA in a cluster. This procedure can be applied to linear networks where the search radius selected is shorter than the distance between adjacent roads.

Next, I used the Mode statistical clustering technique on the Clackamas County carcass pickup reports shape file for 1997-2004 to identify specific locations 
with more than one DVA (Levine 2004). The Mode identifies DVA as occurring at the same location only if they share the same set of $x, y$ coordinates, and ranks locations by number of DVA. I then applied the fuzzy mode statistical clustering routine on these same data to identify the road segments with the densest clusters of DVA using a $0.5 \mathrm{mi}$ search radius (Levine 2004). This technique has two advantages over the mode: 1) it identifies DVA clusters that occur in close proximity but do not share the same $x, y$ coordinates and 2) it helps identify clustered but imprecisely located DVA.

Lastly, I calculated the percentage of DVA occurring within and outside of hotspots. I used the fuzzy mode statistical procedure with a search radius of $0.5 \mathrm{mi}$ and a minimum cluster size of 10 DVA on the Clackamas County carcass pickup reports to determine the percentage of DVA occurring outside of hotspots with $\geq 10$ DVA. I divided the total DVA in hotspots and total DVA outside of hotspots by total DVA, then multiplied by 100 to create a percentage.

\section{Seasonal Shifts of DVA Hotspot Locations}

I determined whether DVA hotspots occur in the same locations throughout the year by creating two GIS shape files, one for DVA occurring in the rut/hunt months (September-November) and one for DVA occurring in the nomrut/nonhunt months (December-August). I identified hotspots in each shape file using the nearest neighbor statistical clustering routine in Crimestat III with a search radius of $0.5 \mathrm{mi}$ and a minimum cluster size of 10 DVA. Based on the number of locations experiencing 
DVA in each season and the total number of DVA for both seasons, I derived the percentage of seasonal overlap.

\section{Landscape Characteristics of DVA Hotspots}

I identified the landscape and road characteristics of the nineteen largest DVA hotspots by layering a GIS shapefile of hotspots over $10^{\prime}$ resolution orthophotography of their surrounding landscape. I then visually searched for landscape and road characteristics identified by white-tailed and mule deer DVA hotspot models in the literature (Table 1) and noted presence or absence of these features (Table 12).

Table 12. Landscape, land use, and visibility variables to be examined for their contribution to deer-vehicle accident hotspots. Source: Table 1.

\section{Land Use Characteristics}

- Scattered residences

- Human-created corridors directing deer to road

\section{Landscape Characteristics}

- Road intersects or parallels riparian corridors/wetlands

- Road adjacent to or intersects large wooded areas

- Area is mix of forest and fields

- Road separates forest and field

\section{Visibility}

- Road has long in-line visibility

- Road has short in-line visibility

- Dense vegetation approaches road on one or both sides 


\section{Vehicle Speed, Traffic Volume, and Road Class of DVA Hotspots}

Several studies have examined the relationship between DVA frequency and vehicle speed, traffic volume, and road class (Allen and McCullough 1976, Bashore et al. 1985, Groot-Bruinderink and Hazebroek 1996, Romin and Bissonette 1996a, Finder 1998, Hubbard et al. 2000). Truck traffic may also be related to DVA frequency because of the longer stopping distance and increased collision impact. I calculated changes in vehicle speed, traffic volume, \% truck traffic, and road class from 1997 to 2002 for each hotspot with >16 DVA using 1997 and 2002 Traffic Counter Studies. For the same hotspots, I determined traffic volume changes from January to November for 1997 and 2002. This procedure involved calculating the daily traffic volume in January, the month with the lowest number of DVA, and in November, the month with the highest number of DVA, using the 1997 and 2002 Traffic Counter Studies and the 2005 Monthly Traffic Count Factors. The daily traffic volume is the monthly average. I then calculated daily traffic volume (DTV) using (Carpenter 2005):

$$
\begin{aligned}
& \mathrm{ADT}=\mathrm{DTV}(\mathrm{Jan}) \times \mathrm{TAF} \times \mathrm{RMTCF}(\mathrm{Jan}) . \\
& \text { Therefore: DTV }(\text { Jan })=\text { ADT/(TAF } x \text { RMTCF (Jan)) } \\
& \text { Where: } \quad \mathrm{ADT}=\text { Average Daily Traffic (the annual average) } \\
& \text { DTV = Daily Traffic Volume (the monthly average) } \\
& \mathrm{TAF}=\text { Truck Axle Factor }(\text { average }=0.89) \\
& \text { RMTCF }=\text { Rural Monthly Traffic Count Factor }
\end{aligned}
$$




\section{CHAPTER 4}

\section{RESULTS}

\section{Spatial and Temporal DVA Patterns}

\section{Annual and Seasonal DVA Patterns}

Deer-vehicle accidents in northwest Clackamas County show clear annual and seasonal patterns. Carcass pickups rose rapidly from 1997-1999 followed by a general decline until 2004 (Figure 5, Table 13). Monthly carcass pickups for all years were lowest January-April. Monthly carcass pickups increased in May, peaking in October and November before declining abruptly in December (Figure 6). These monthly carcass pickup patterns occurred each year for Clackamas County (Figure 7). The ODOT deer-vehicle accident reports for 1996-2004 for Clackamas, Washington, and Multnomah Counties expressed a similar pattern (Figure 8). 


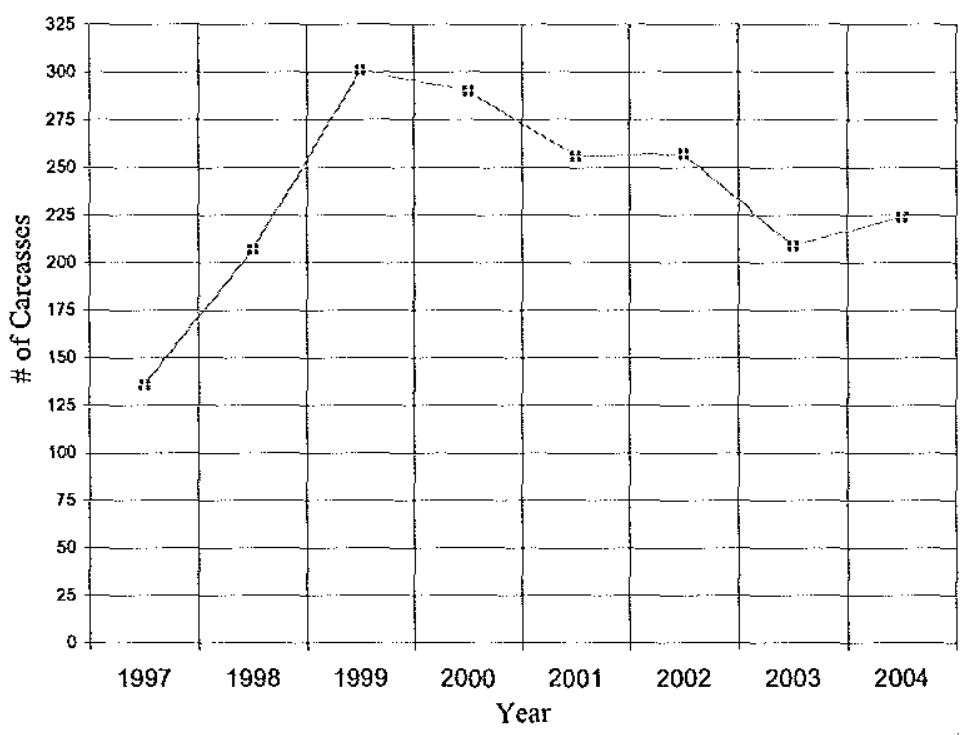

Figure 5. Annual pattern of carcass pickups for Clackamas County, 1997-2004. Source: Clackamas County carcass pickup reports, 1997-2004.

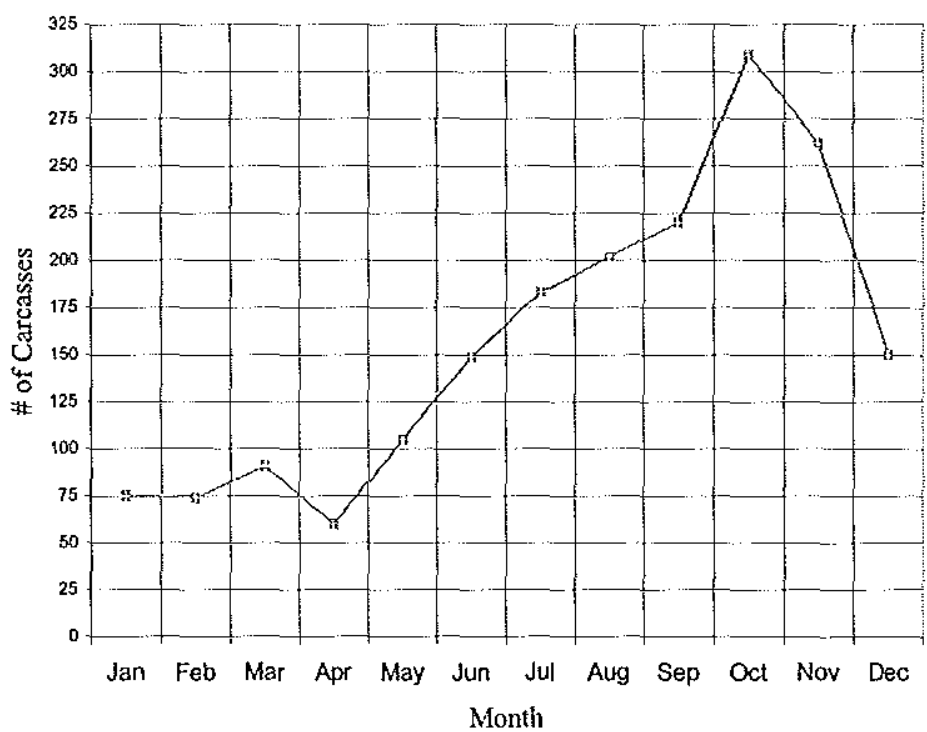

Figure 6. Carcass pickups by month for all years combined, Clackamas County, 1997-2004. Source: Clackamas County carcass pickup reports, 1997-2004. 
Table 13. Annual and monthly summary statistics for deer carcass pickups for northwest Clackamas County, 1997-2004. Source: Clackamas County carcass pickup reports, 1997-2004.

\begin{tabular}{|l|r|r|r|r|r|r|r|r|r|r|r|r|r|}
\hline & 1997 & 1998 & 1999 & 2000 & 2001 & 2002 & $\mathbf{2 0 0 3}$ & $\mathbf{2 0 0 4}$ & Total & Mean & Median & $\begin{array}{l}\text { Std } \\
\text { Dev }\end{array}$ & Range \\
\hline Month & & & & & & & & & & & & & \\
\hline Jan & 2 & 4 & 8 & 13 & 17 & 14 & 10 & 7 & $\mathbf{7 5}$ & 9.4 & 9.0 & 5.125 & $2-17$ \\
\hline Feb & 7 & 4 & 11 & 9 & 11 & 11 & 10 & 11 & $\mathbf{7 4}$ & 9.3 & 10.5 & 2.550 & $4-11$ \\
\hline Mar & 9 & 13 & 6 & 18 & 10 & 6 & 15 & 14 & $\mathbf{9 1}$ & 11.4 & 11.5 & 4.340 & $6-18$ \\
\hline Apr & 6 & 9 & 10 & 7 & 4 & 10 & 9 & 5 & $\mathbf{6 0}$ & 7.5 & 8.0 & 2.330 & $4-10$ \\
\hline May & 9 & 4 & 21 & 13 & 16 & 23 & 12 & 7 & 105 & 13.1 & 12.5 & 6.621 & $4-23$ \\
\hline Jun & 14 & 17 & 24 & 18 & 23 & 21 & 12 & 20 & $\mathbf{1 4 9}$ & 18.6 & 19.0 & 4.207 & $12-24$ \\
\hline Jul & 8 & 25 & 26 & 27 & 21 & 27 & 27 & 22 & 183 & 22.9 & 25.5 & 6.446 & $8-27$ \\
\hline Aug & 5 & 24 & 39 & 35 & 23 & 22 & 31 & 23 & $\mathbf{2 0 2}$ & 25.3 & 23.5 & 10.348 & $5-39$ \\
\hline Sep & 14 & 32 & 35 & 24 & 31 & 37 & 20 & 27 & $\mathbf{2 2 0}$ & 27.5 & 29.0 & 7.838 & $14-37$ \\
\hline Oct & 22 & 39 & 43 & 57 & 35 & 46 & 32 & 35 & $\mathbf{3 0 9}$ & 38.6 & 37.0 & 10.405 & $22-57$ \\
\hline Nov & 27 & 29 & 47 & 49 & 36 & 23 & 21 & 30 & $\mathbf{2 6 2}$ & 32.8 & 29.5 & 10.457 & $21-49$ \\
\hline Dec & 13 & 7 & 31 & 20 & 29 & 17 & 10 & 23 & $\mathbf{1 5 0}$ & 18.8 & 18.5 & 8.664 & $7-31$ \\
\hline Total & 136 & 207 & 301 & 290 & 256 & $\mathbf{2 5 7}$ & $\mathbf{2 0 9}$ & $\mathbf{2 2 4}$ & $\mathbf{1 8 8 0}$ & & & & \\
\hline Mean & 11.3 & 17.3 & 24.3 & 24.2 & 21.3 & 21.4 & 17.4 & 18.7 & & & & & \\
\hline Median & 9.0 & 15.0 & 25.0 & 19.0 & 22.0 & 21.5 & 13.5 & 21.0 & & & & & \\
\hline $\begin{array}{l}\text { Std } \\
\text { Dev }\end{array}$ & 7.215 & 12.256 & 13.081 & 15.631 & 10.192 & 11.421 & 8.575 & 9.792 & & & & & \\
\hline Range & $2-27$ & $4-39$ & $6-43$ & $7-57$ & $4-36$ & $6-46$ & $9-32$ & $5-35$ & & & & \\
\hline
\end{tabular}




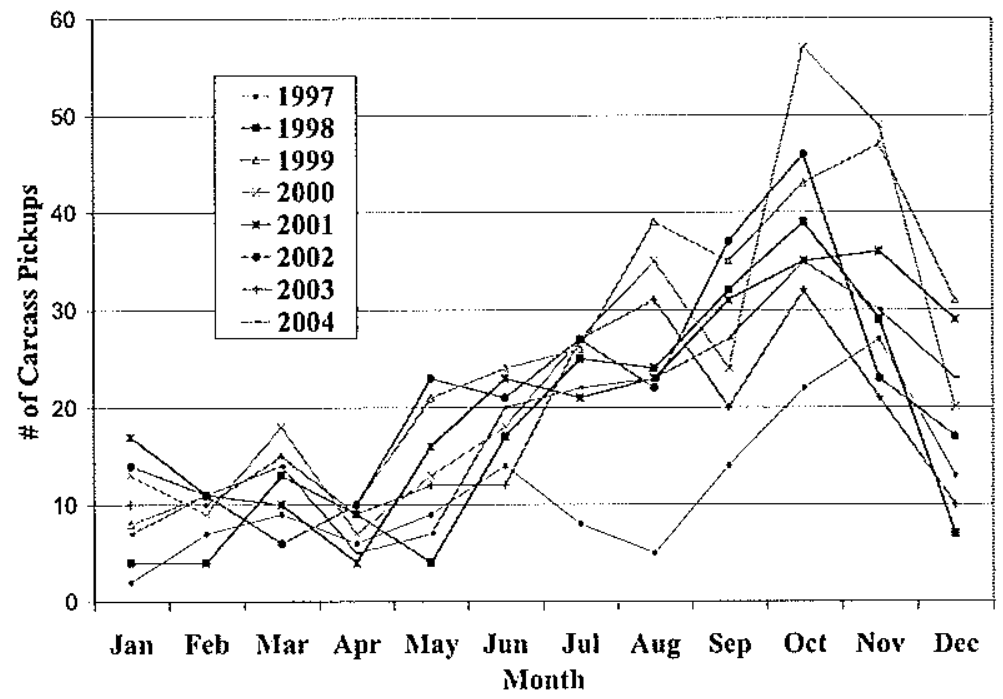

Figure 7. Carcass pickups for all months and all years, Clackamas County, 1997-2004. Source: Clackamas County carcass pickup reports, 1997-2004.

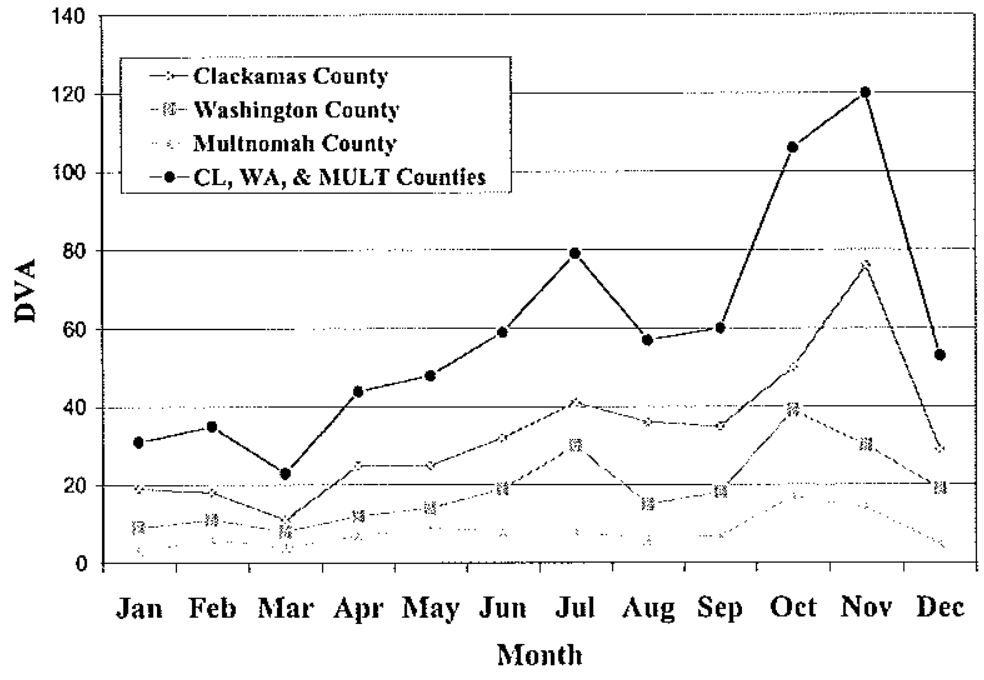

Figure 8. ODOT deer-vehicle accident reports by month, all years combined, for Clackamas, Washington, and Multnomah Counties, 1996-2004. Source: ODOT deer-vehicle accident reports, 1996-2004. 
Seasonal DVA and Deer Activity Patterns

Superimposing the deer seasonal activity pattern over DVA patterns shows DVA are lowest during the winter reclusion period, December-February. DVA rise slightly in March when plant growth resumes in Clackamas County. DVA drop again in April, begin to rise again in May when does return to fawning sites, and continue rising through June and July when yearlings are driven away from new born fawns by does and when yearling males seek their own territories. Some years show a decline in DVA in August and others a decline in September, but all years then show peak DVA in either October or November during the rutting and hunting seasons (Figure 9). DVA occurring during the three rut months of September, October, and November, for all years combined, account for $42 \%$ (STD: $4.18 \%$; Range: $3.4 \%$ ) of DVA between 1997-2004 (Table 14). 


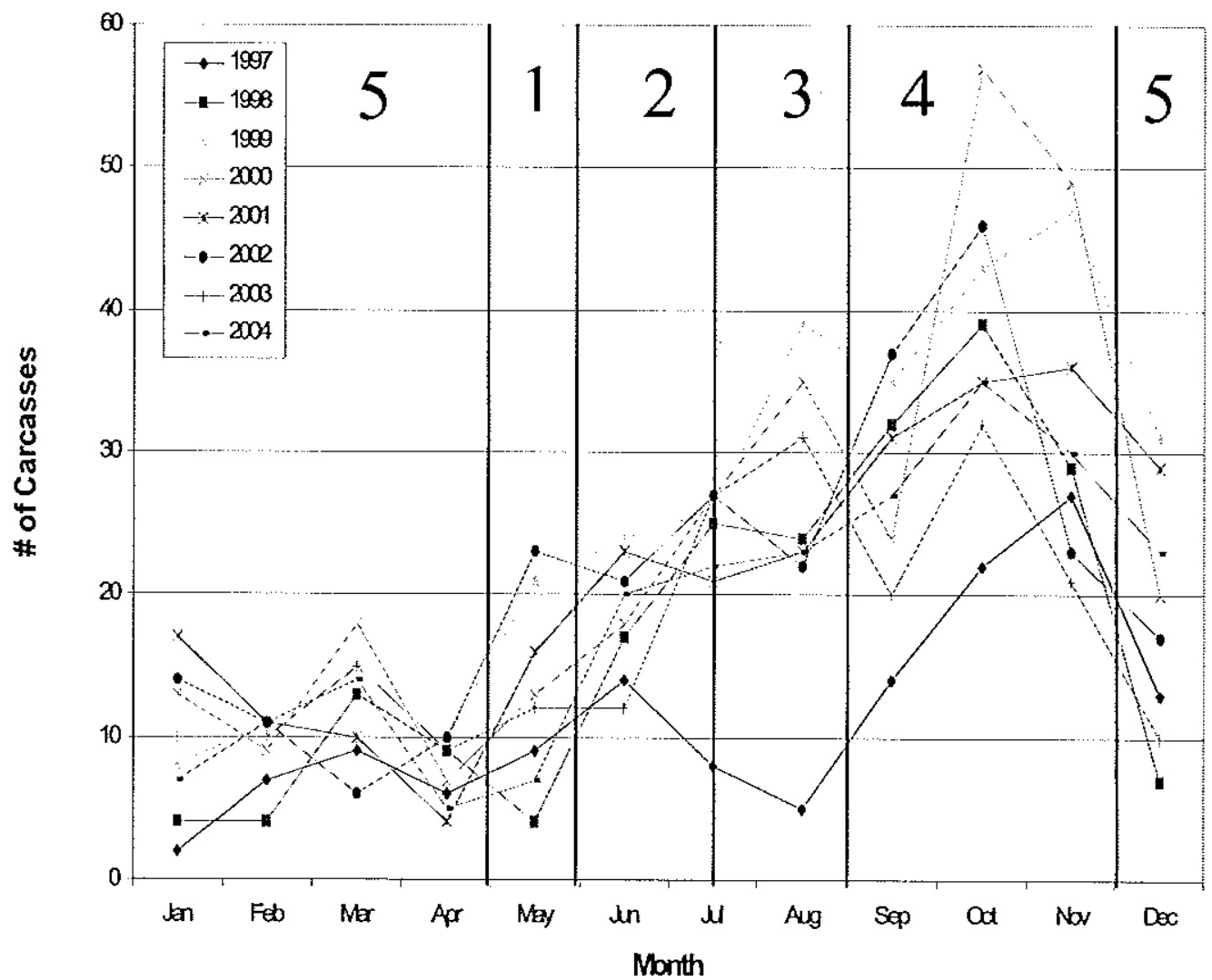

Figure 9. Correspondence between black-tailed deer annual life cycle and annual DVA cycle for Clackamas County, 1997-2004. Band 1: Does return to fawning grounds. Band 2: Doe drives off yearlings and juvenile males establish territories. Band 3: Does and fawns emerge from hiding. Band 4: Rut and hunt. Band 5: Deer resting. 
Table 14. Percentage of DVA occurring during the rut months, SeptemberNovember, in northwest Clackamas County, 1997-2004.

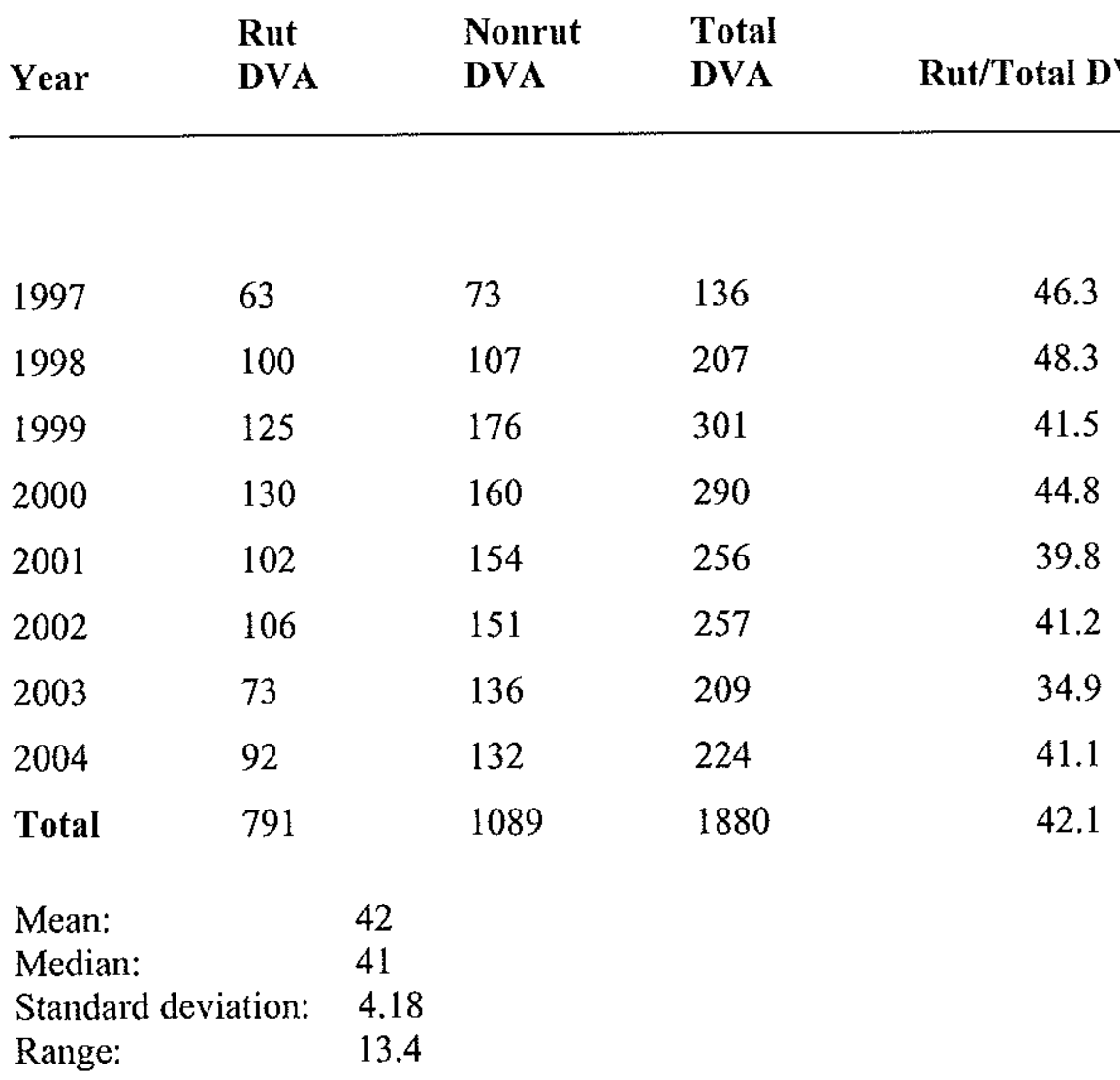

\section{Day-of-Week DVA Pattern}

Percentages of Clackamas County DVA occurring on each weekday between 1997 and 2004 show DVA were lowest on Sunday and gradually increased throughout the week, peaking on Saturday (Figure 10, Table 15). I found no additional week-day patterns occurring monthly or with months condensed into: 1) a 3-month deer seasonal cycle, 2) a 4-month deer seasonal cycle, and 3) a 3-month 
climate season. Weekday DVA for all three Metro counties, Clackamas,

Washington, and Multnomah also failed to show a consistent day-of-week pattern.

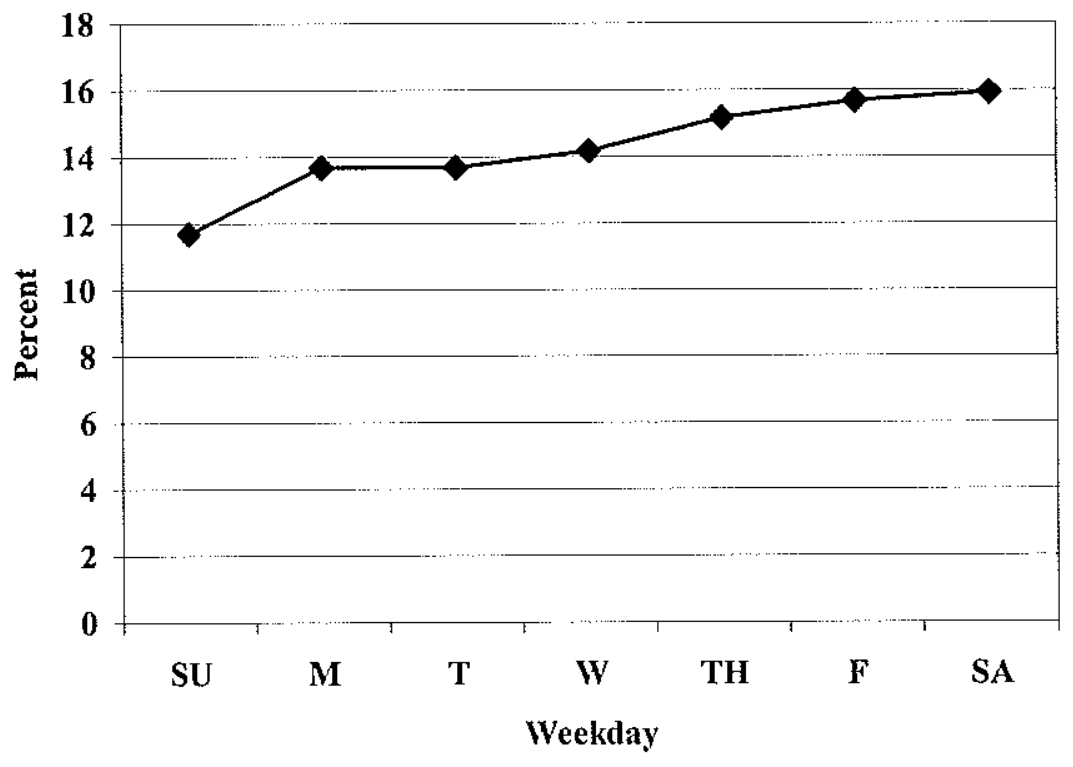

Figure 10. Percentage of total DVA by day of week for Clackamas County, all months and all years combined, 1996-2004. Source: ODOT deer-vehicle accident reports.

Table15. Day-of-week DVA as percentage of monthly DVA. $\mathrm{N}=397$ reports. Source: ODOT deer-vehicle accident reports, Clackamas County, 1996-2004.

$\begin{array}{lrrrrrrrr} & \text { SU } & \text { M } & \text { T } & \text { W } & \text { TH } & \text { F } & \text { SA } & \text { Total } \\ \text { JAN } & 10.5 & 5.3 & 21.1 & 15.8 & 10.5 & 15.8 & 21.1 & 100.0 \\ \text { FEB } & 16.7 & 5.6 & 11.1 & 22.2 & 22.2 & 11.1 & 11.1 & 100.0 \\ \text { MAR } & 9.1 & 18.2 & 18.2 & 18.2 & 9.1 & 18.2 & 9.1 & 100.0 \\ \text { APR } & 12.0 & 16.0 & 28.0 & 8.0 & 8.0 & 16.0 & 12.0 & 100.0 \\ \text { MAY } & 28.0 & 12.0 & 16.0 & 8.0 & 16.0 & 20.0 & 0.0 & 100.0 \\ \text { JUN } & 12.1 & 15.2 & 18.2 & 18.2 & 3.0 & 9.1 & 24.2 & 100.0 \\ \text { JULY } & 7.3 & 22.0 & 9.8 & 19.5 & 7.3 & 12.2 & 22.0 & 100.0 \\ \text { AUG } & 8.1 & 10.8 & 13.5 & 13.5 & 21.6 & 13.5 & 18.9 & 100.0 \\ \text { SEPT } & 8.6 & 17.1 & 14.3 & 11.4 & 14.3 & 8.6 & 25.7 & 100.0 \\ \text { OCT } & 11.8 & 3.9 & 9.8 & 15.7 & 13.7 & 29.4 & 15.7 & 100.0 \\ \text { NOV } & 12.8 & 16.7 & 10.3 & 14.1 & 21.8 & 12.8 & 11.5 & 100.0 \\ \text { DEC } & 6.9 & 17.2 & 10.3 & 6.9 & 24.1 & 20.7 & 13.8 & 100.0 \\ \text { Total } & 11.7 & 13.7 & 13.7 & 14.2 & 15.2 & 15.7 & 15.9 & 100.0\end{array}$


JAN

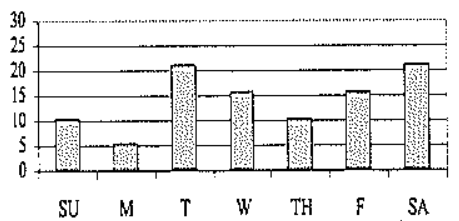

FEB

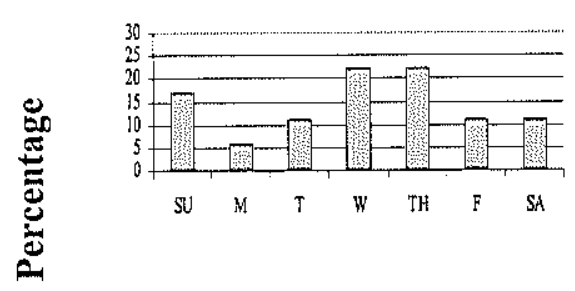

MAR

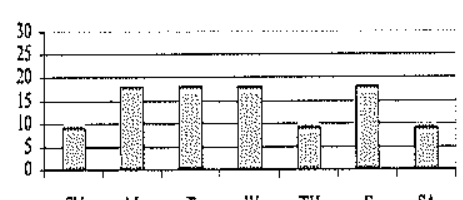

APR

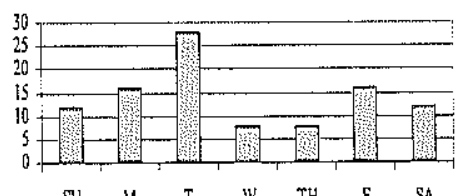

SU $M$ I $\quad$ W

MAY

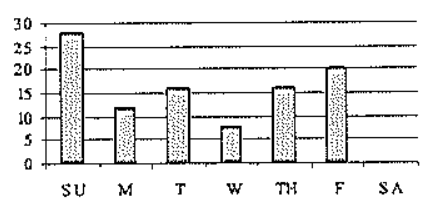

JNE

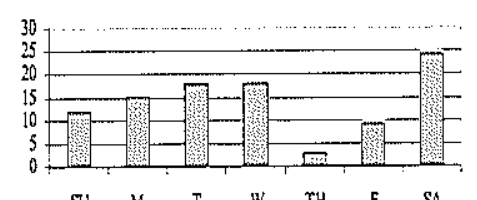

JUL

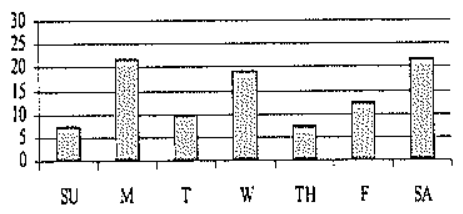

AUG

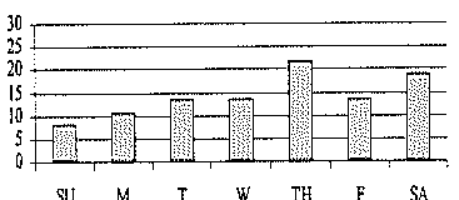

SEPT

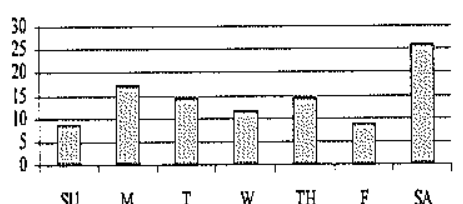

OCT

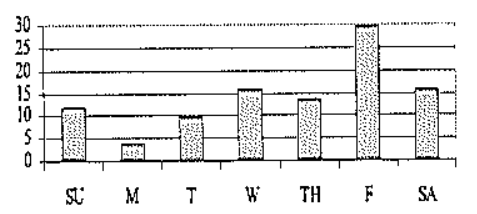

NOV

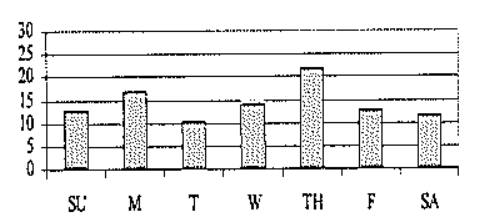

DEC

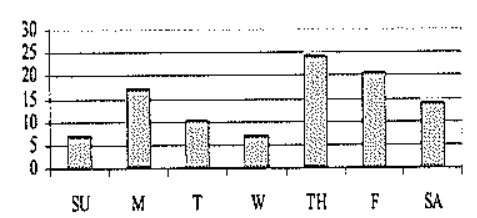

Day of week

Figure 11. Percentage of monthly DVA occurring on each day of week, Clackamas County, 1996-2004. No Saturday DVA occurred in May. Source: ODOT deer-vehicle accident reports, 1996-2004. 


\section{Daily DVA Pattern}

DVA incidents for all months and all years combined showed two daily peaks. Morning DVA begin to increase at 0300 , peak from $0500-0700$, and decline from 0700-0800. Evening DVA begin to increase at 1700, peak from 1800-2200, and drop off at 2200 , declining to a low at 0200 . DVA are lowest from $1100-1600$ with a small peak at 1300 (Figure 12). DVA incidents for Washington and Multnomah Counties show similar patterns (Figure 13).

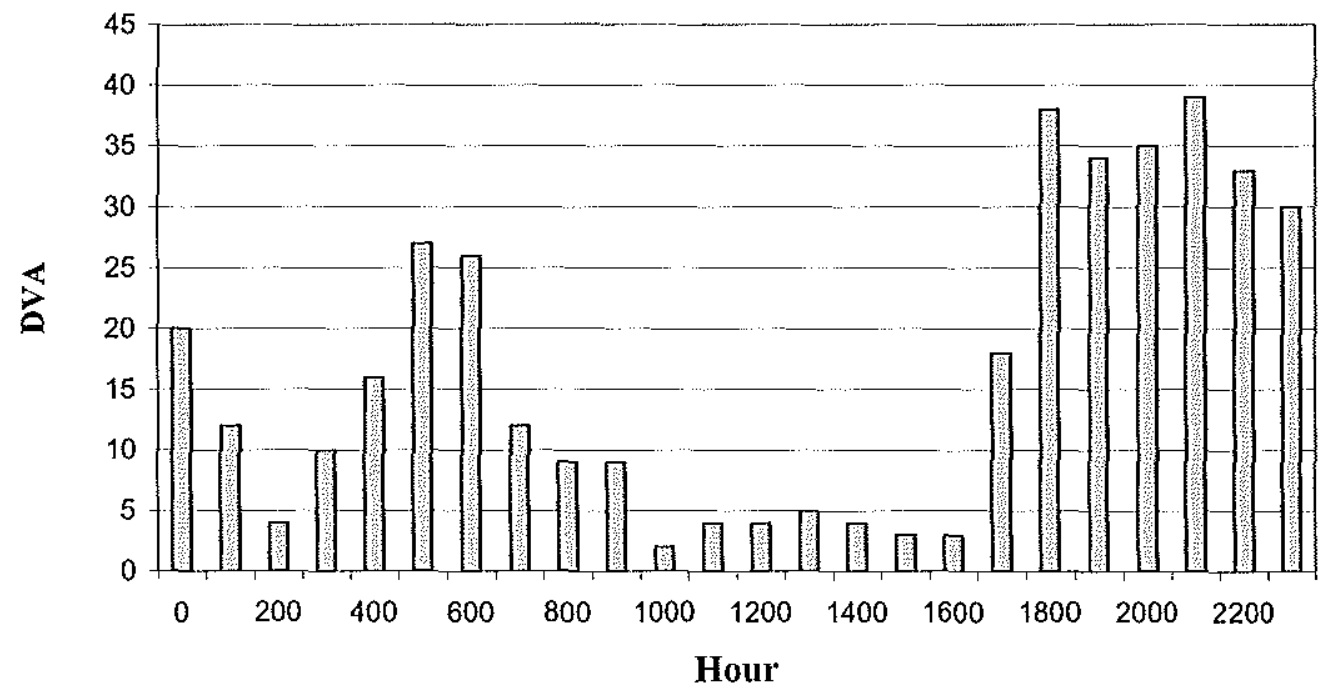

Figure 12. ODOT Deer-vehicle accident reports by hour, all months and years combined, for Clackamas County, 1996-2004. Source: ODOT deer vehicle accident reports, 1996-2004. 


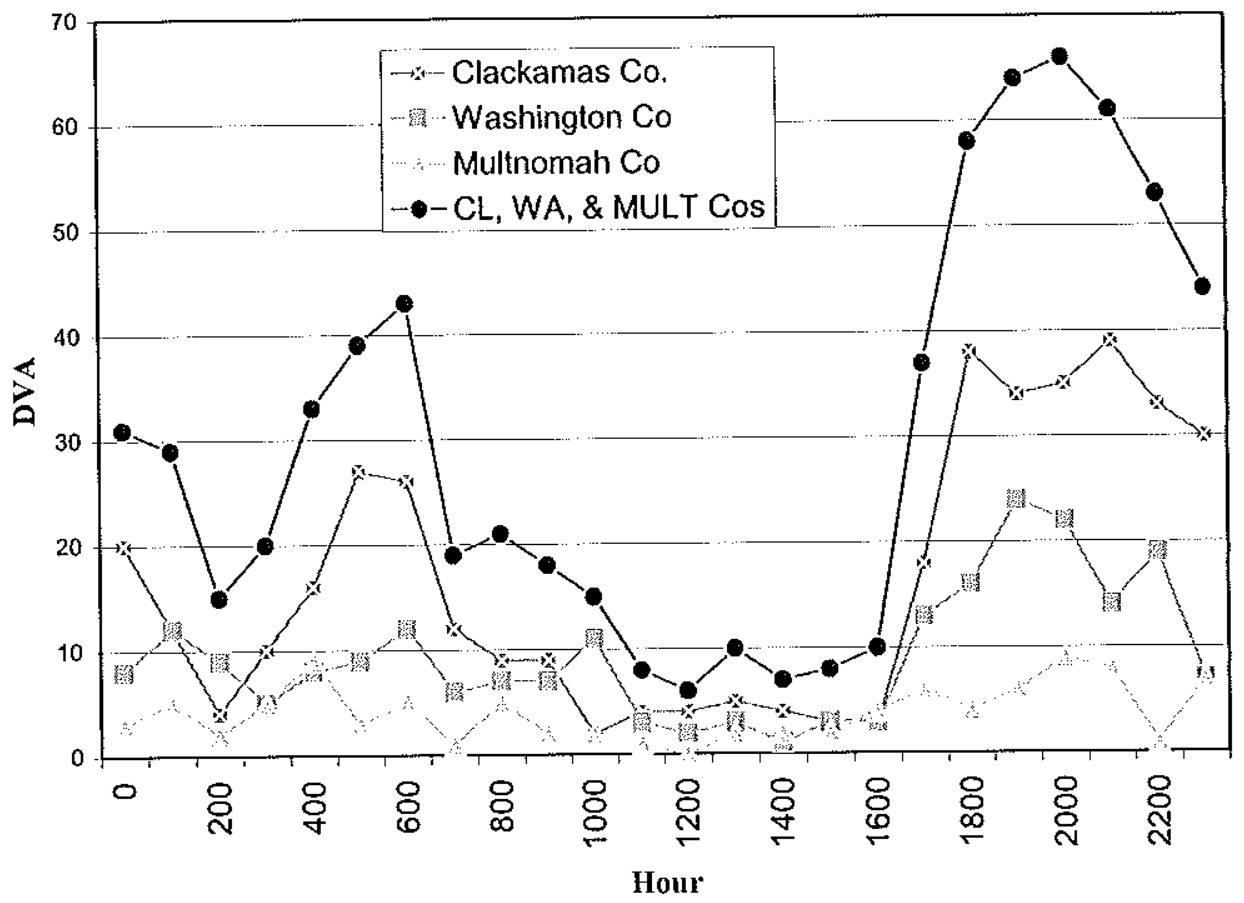

Figure 13. ODOT deer-vehicle accident reports by hour, all months and years combined, for Clackamas, Washington, and Multnomah Counties, 1996-2004. Source: ODOT deer-vehicle accident reports, 1996-2004.

DVA occurring at dawn and "dusk +2 hours" (228 DVA) represent $57.4 \%$ of annual DVA; this time period represents $29.2 \%$ of total hours. DVA occurring when dawn and morning rush hour overlapped (38 DVA) represent $9.6 \%$ of annual DVA; this time period represents $4.9 \%$ of total annual hours. DVA occurring when evening rush hours and "dusk +2 hours" overlapped (43 DVA) represent $10.8 \%$ of annual DVA; this time period represents $4.9 \%$ of total annual hours. Most DVA $(\approx 83 \%)$, occurred in dark hours, defined as the hours between sunset and sunrise; this period occupied $\approx 53 \%$ of total annual hours. The light period, defined as the hours between 
sunrise and sunset, represented $\approx 17 \%$ of total DVA and represented $\approx 47 \%$ of total annual hours. One hundred and fourteen DVA, or $28.7 \%$ of total DVA, occurred during morning and evening rush hours; these periods combined represented $25 \%$ of total annual hours (Table 16, Figure 14). 
Table 16. Overlap of DVA with dawn, and dusk +2 hours, morning and evening rush hours, Clackamas County, 1996-2004. Source: ODOT deer-vehicle accident reports, 1996-2004.

\begin{tabular}{|c|c|c|c|c|}
\hline Period of Day & $\begin{array}{l}\text { \# of } \\
\text { DVA }\end{array}$ & $\begin{array}{l}\text { Percent } \\
\text { of Total } \\
\text { DVA }\end{array}$ & $\begin{array}{l}\text { \# of } \\
\text { Hours }\end{array}$ & $\begin{array}{l}\text { Percent } \\
\text { of Total } \\
\text { Hours } \\
\end{array}$ \\
\hline Dawn & 61 & 15.4 & 29 & 10.1 \\
\hline Dusk +2 hours & 167 & 42.1 & 55 & 19.0 \\
\hline Dawn and Dusk +2 hours & 228 & 57.4 & 84 & 29.2 \\
\hline Morning rush hour & 63 & 15.9 & 36 & 12.5 \\
\hline Evening rush hour & 51 & 12.8 & 36 & 12.5 \\
\hline Morning and Evening rush hour & 114 & 28.7 & 72 & 25.0 \\
\hline Dawn $=$ morning rush hour & 38 & 9.6 & 14 & 4.9 \\
\hline Dusk +2 hours $=$ evening rush hour & 43 & 10.8 & 14 & 4.9 \\
\hline Dark hours (sunset to sunrise) & 330 & 83.1 & 154 & 53.5 \\
\hline Light hours (sunrise to sunset) & 67 & 16.9 & 134 & 46.5 \\
\hline
\end{tabular}




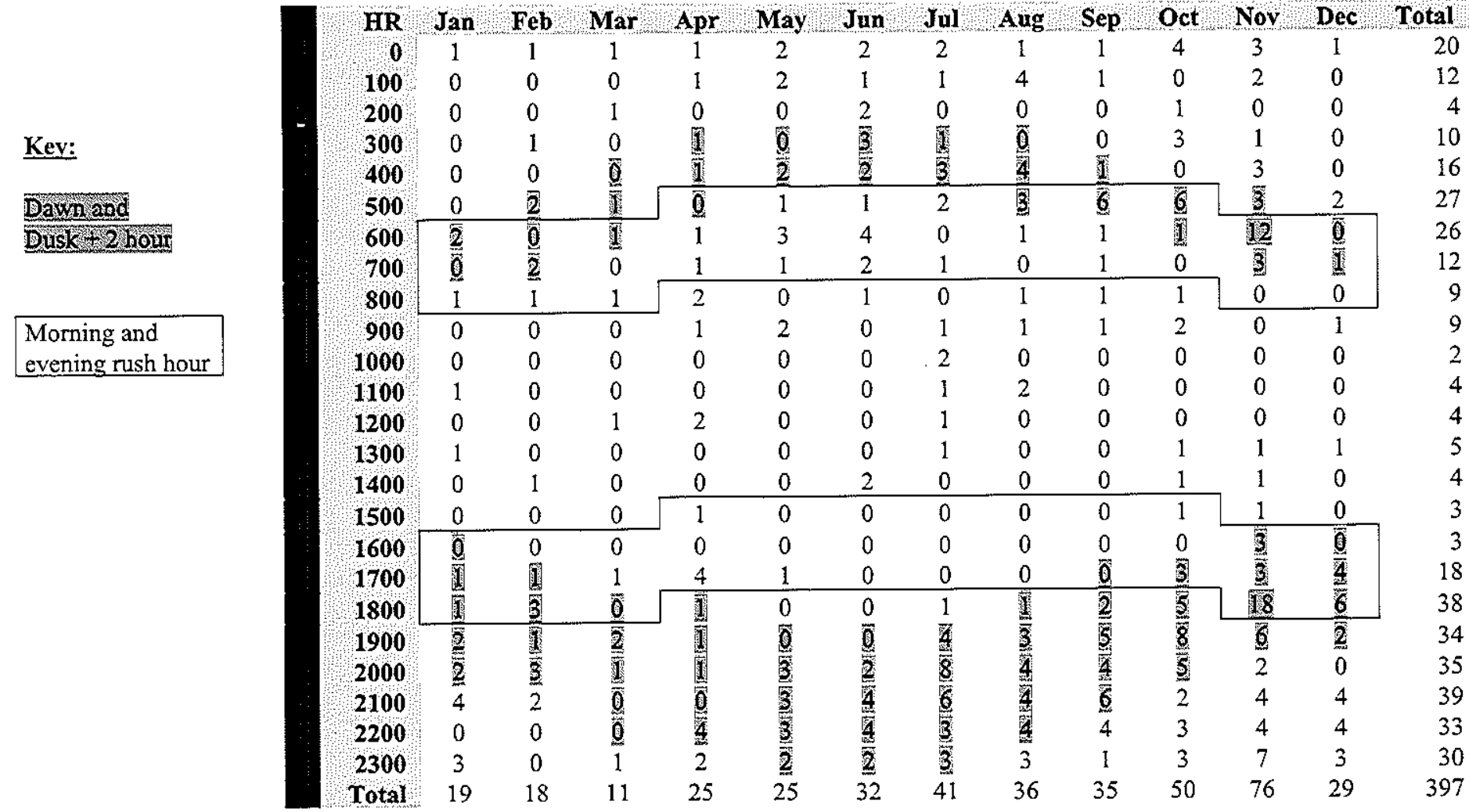

Figure 14. Overlap of Clackamas County DVA with dawn, dusk, morning and evening rush hours. Source: ODOT deer-vehicle accident reports, 1996-2004. 


\section{DVA Hotspot Identification}

I applied three statistical clustering routines, mode, fuzzy mode, and nearest neighbor (CrimeStat III 2005) to each of my 1880 carcass pickup locations. These routines identified locations having 1) more than one DVA, 2) road segments with the densest clusters of DVA, and 3) DVA hotspots. The routines failed to include 27 DVA locations, producing results for 1853 DVA.

Using the mode routine I identified one location with eight DVA, two locations with seven DVA, nine locations recording five DVA, and twenty-two locations at which four DVA occurred between 1997 and 2004 (Figure 15). The fuzzy mode identified the frequency of DVA within a $0.5 \mathrm{mi}$ radius of each DVA. These results reveal three DVA clusters with 942 DVA (63\% of total) having 1-7 other DVA within a $0.5 \mathrm{mi}$ search radius, 429 DVA ( $29 \%$ of total) having $8-15$ other DVA within a 0.5 mi search radius, and 129 DVA ( $9 \%$ of total) having $16-27$ other DVA within a $0.5 \mathrm{mi}$

search radius (Figure 4, Appendix D). A frequency map (Figure 16) uses these divisions to display the locations of the densest frequencies of DVA. 


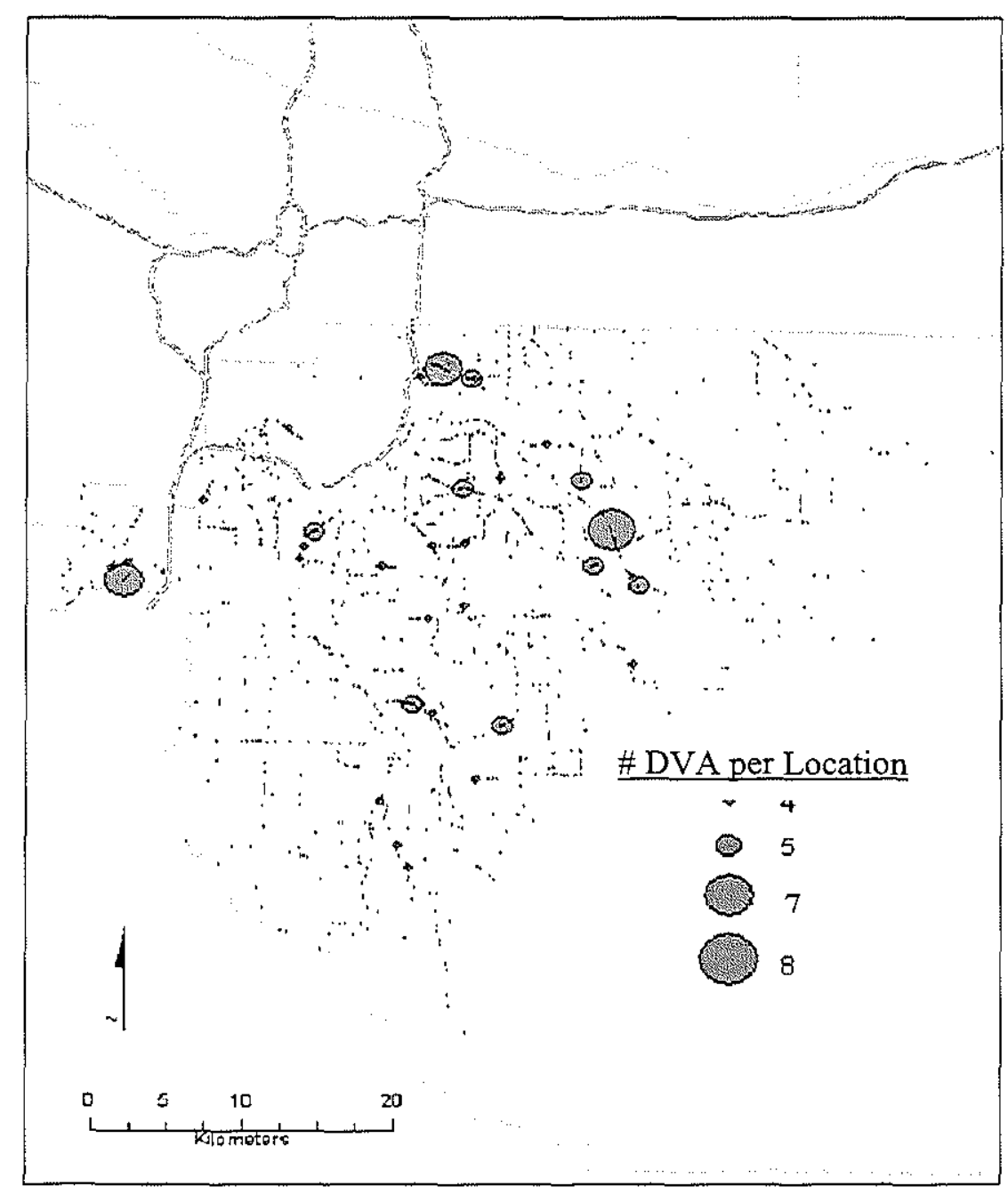

Figure 15. Number of deer-vehicle accidents occurring at each unique pair of $x, y$ coordinates (graduated symbols) and all DVA (dots). Source: Crimestat III Mode and Clackamas County carcass pickup reports, 1997-2004.

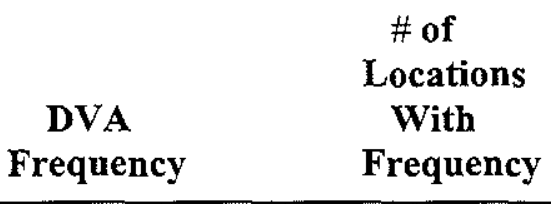

1

7

2

$6 \quad 0$

$5 \quad 9$

4

22

3

42

2

148

1

1276 


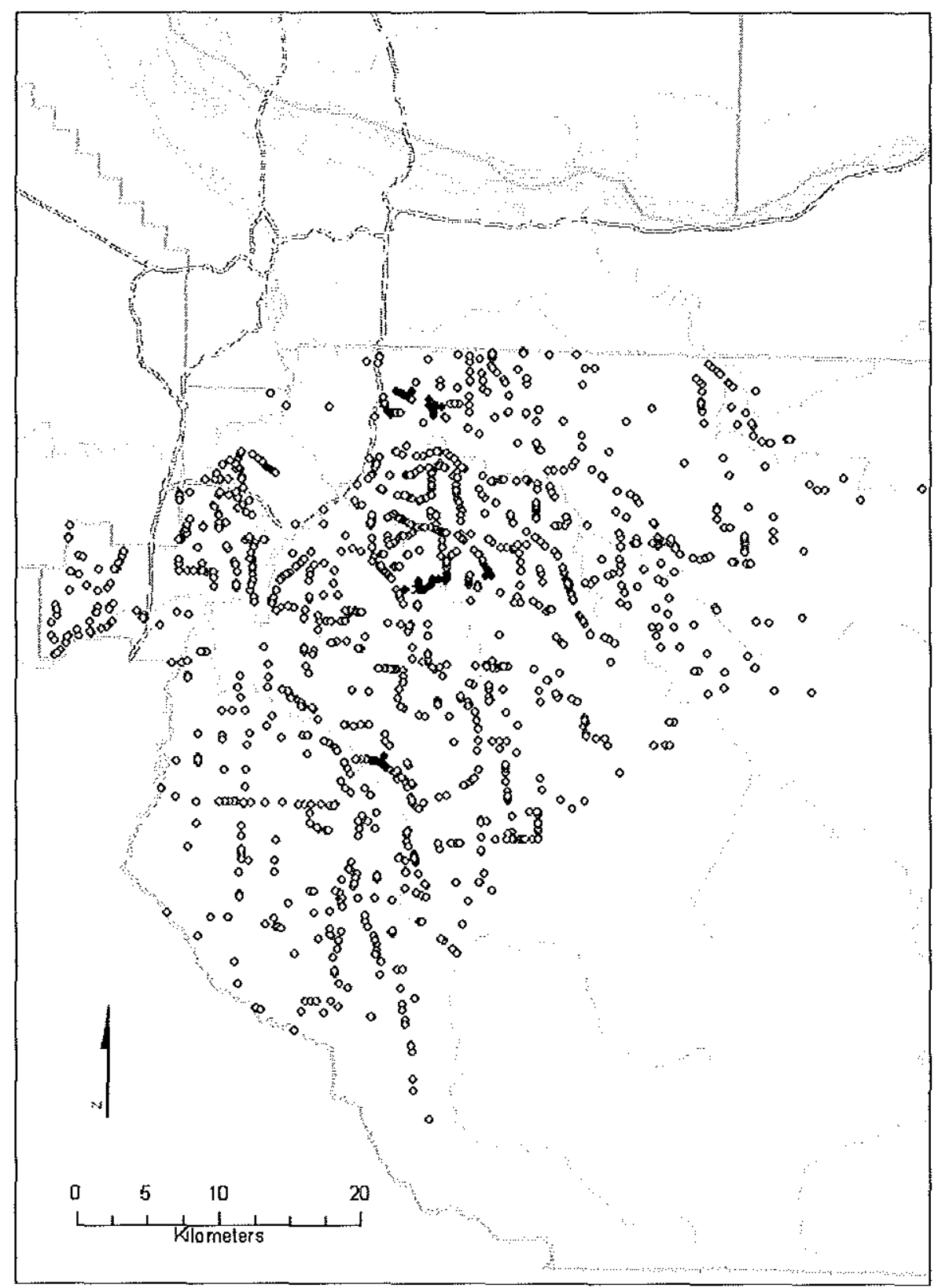

Figure 16. Frequency of DVA within a $0.5 \mathrm{mi}$ radius of each DVA. Black: frequency of 16-27 DVA. Grey: frequency of 8-15 DVA. White: frequency of 1-7 DVA. Clackamas County, 1997-2004. 
I used two forms of nearest neighbor analysis to identify DVA hotspots. The nearest neighbor analysis using a probability of $5 \%$ of including random DVA in DVA clusters and a minimum cluster size of 10 DVA, identified 37 of the 41 DVA clusters identified in Option 1 (Table 17). The nearest neighbor analysis using a fixed search radius of $0.5 \mathrm{mi}$ and minimum cluster size of $10 \mathrm{DVA}$, identified 41 DVA hotspot clusters, containing 11-27 DVA (Table 17, Figure 17, Appendix E). This procedure identified 17 DVA hotspot clusters using a search radius of $0.25 \mathrm{mi}$ and 4 DVA hotspot clusters using a search radius of $0.125 \mathrm{mi}$ (Appendix F). 
Table 17. Comparison of DVA density for 41 DVA hotspots (DVA clusters) identified by nearest neighbor analysis at $0.5 \mathrm{mi}$ search radius with minimum cluster and 37 DVA hotspots identified by nearest neighbor analysis with $5 \%$ probability and minimum cluster size of 10 DVA.

\begin{tabular}{|c|c|c|c|c|c|}
\hline \multirow[t]{2}{*}{ Cluster } & \multicolumn{2}{|c|}{ DVA Density } & \multirow[t]{2}{*}{ Cluster \# } & \multicolumn{2}{|c|}{ DVA Density } \\
\hline & $\begin{array}{l}\text { mi } \\
\text { ch radius }\end{array}$ & $\begin{array}{c}5 \% \\
\text { probability }\end{array}$ & & $\begin{array}{l}0.5 \mathrm{mi} \\
\text { earch radius }\end{array}$ & $\begin{array}{l}5 \% \\
\text { probability }\end{array}$ \\
\hline 1 & 27 & 25 & 22 & 15 & 15 \\
\hline 2 & 26 & 24 & 23 & 15 & 13 \\
\hline 3 & 25 & 25 & 24 & 15 & 14 \\
\hline 4 & 20 & 19 & 25 & 15 & no cluster \\
\hline 5 & 22 & 21 & 26 & 14 & 14 \\
\hline 6 & 21 & 21 & 27 & 14 & 14 \\
\hline 7 & 21 & 20 & 28 & 14 & 13 \\
\hline 8 & 20 & 19 & 29 & 13 & 13 \\
\hline 9 & 13 & 15 & 30 & 13 & 13 \\
\hline 10 & 19 & 16 & 31 & 13 & 11 \\
\hline 11 & 13 & 18 & 32 & 13 & 12 \\
\hline 12 & 12 & * & 33 & 13 & 13 \\
\hline 13 & 18 & 18 & 34 & 12 & 12 \\
\hline 14 & 18 & 17 & 35 & 12 & no cluster \\
\hline 15 & 16 & 15 & 36 & 12 & 12 \\
\hline 16 & 16 & 15 & 37 & 11 & 11 \\
\hline 17 & 16 & 16 & 38 & 11 & no cluster \\
\hline 18 & 16 & 14 & 39 & 11 & 11 \\
\hline 19 & 16 & 15 & 40 & 11 & no cluster \\
\hline 20 & 15 & 14 & 41 & 11 & 11 \\
\hline 21 & 15 & 12 & & no cluster & 11 \\
\hline
\end{tabular}

*included in cluster \# 11 


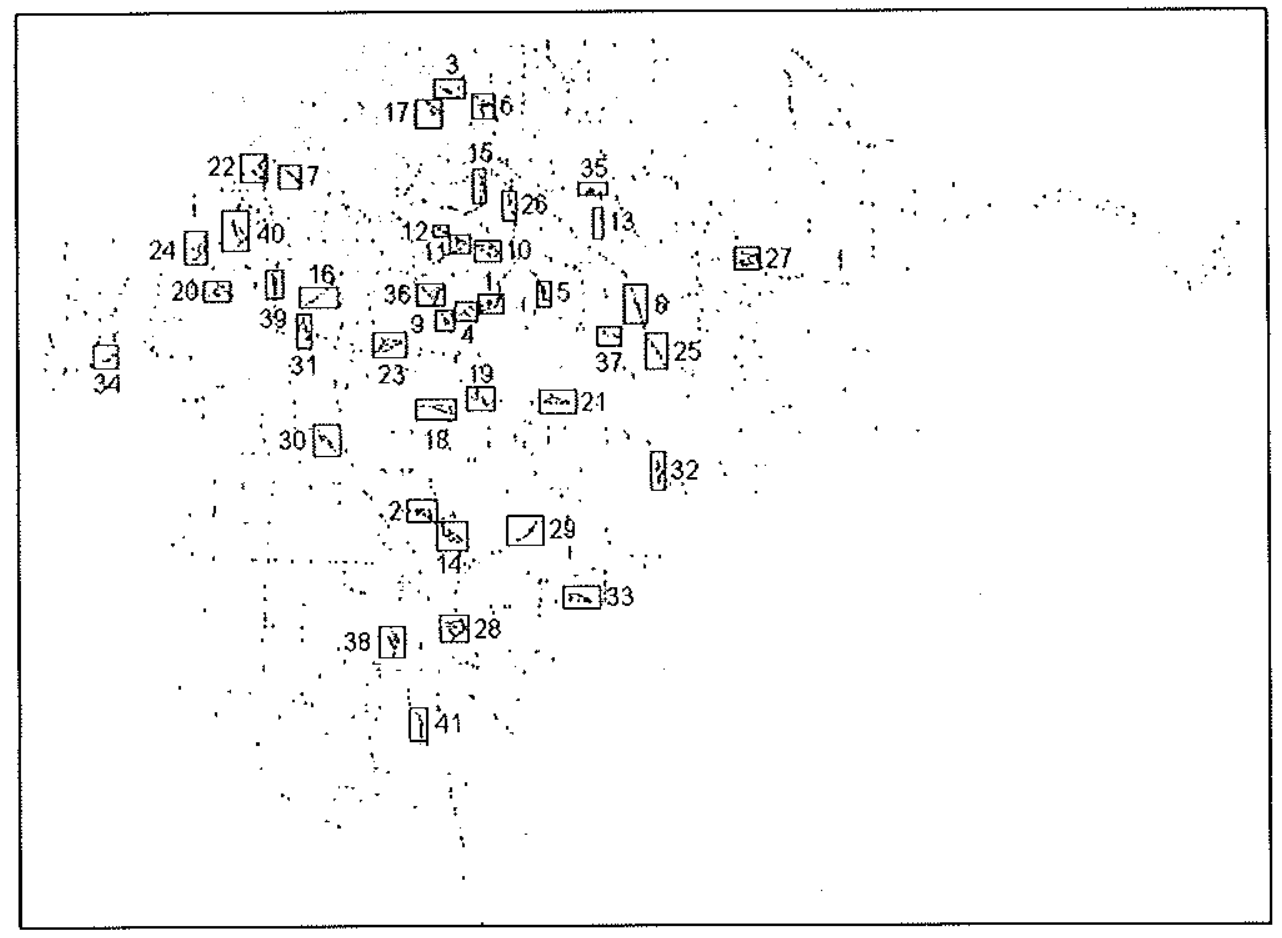

Figure 17. DVA hotspot clusters (boxes) with $\geq 10$ DVA at $0.5 \mathrm{mi}$ search radius for Clackamas County, 1997-2004. Number $=$ cluster identification number. See Appendix F for number of DVA in each cluster. Clackamas County, 1997-2004. 


\section{Percent of DVA Occurring Outside of Hotspots}

I calculated the number of DVA occurring within and outside of hotspots

containing $\geq 10$ DVA. Thirty-five percent of all DVA occurred within hotspots; sixtyfive percent of all DVA occurred outside of hotspots (Table 18).

Table 18. Frequency of DVA hotspots identified by CrimeStat III fuzzy mode analysis at search radius of $0.5 \mathrm{mi}$ containing $\geq 10 \mathrm{DVA}$.

\begin{tabular}{|c|c|c|}
\hline DVA/Hotspot & \# of Hotspots & Total DVA \\
\hline 27 & 1 & 27 \\
\hline 26 & 1 & 26 \\
\hline 25 & 1 & 25 \\
\hline 24 & 0 & 0 \\
\hline 23 & 0 & 0 \\
\hline 22 & 1 & 22 \\
\hline 21 & 2 & 42 \\
\hline 20 & 2 & 40 \\
\hline 19 & 1 & 19 \\
\hline 18 & 2 & 36 \\
\hline 17 & 0 & 0 \\
\hline 16 & 5 & 80 \\
\hline 15 & 6 & 90 \\
\hline 14 & 3 & 42 \\
\hline 13 & 7 & 91 \\
\hline 12 & 4 & 48 \\
\hline 11 & 5 & 55 \\
\hline 10 & 0 & 0 \\
\hline \multicolumn{2}{|c|}{ Total DVA } & 1,853 \\
\hline \multicolumn{2}{|c|}{ Total DVA Occurring in Hotspots } & -643 \\
\hline \multicolumn{2}{|c|}{ Total DVA Occurring Outside of Hotspots } & $\overline{1,210}$ \\
\hline \multicolumn{2}{|c|}{ Percentage of DVA Occurring in Hotspots: } & $35 \%$ \\
\hline \multicolumn{2}{|c|}{ Percentage of DVA Occurring Outside of Hotspots: } & $65 \%$ \\
\hline
\end{tabular}




\section{Seasonal Shifts of DVA Hotspot Locations}

The nearest neighbor clustering routine, using a $0.5 \mathrm{mi}$ search radius and minimum cluster size of 10 DVA, identified 9 rut/hunt and 9 nonrut/nonhunt DVA hotspots (Table 19). Two road segments were hotspots during both the rut/hunt and nonrut/nonhunt months (Figure 18). Overlap $=5 / 18$ or $28 \%$.

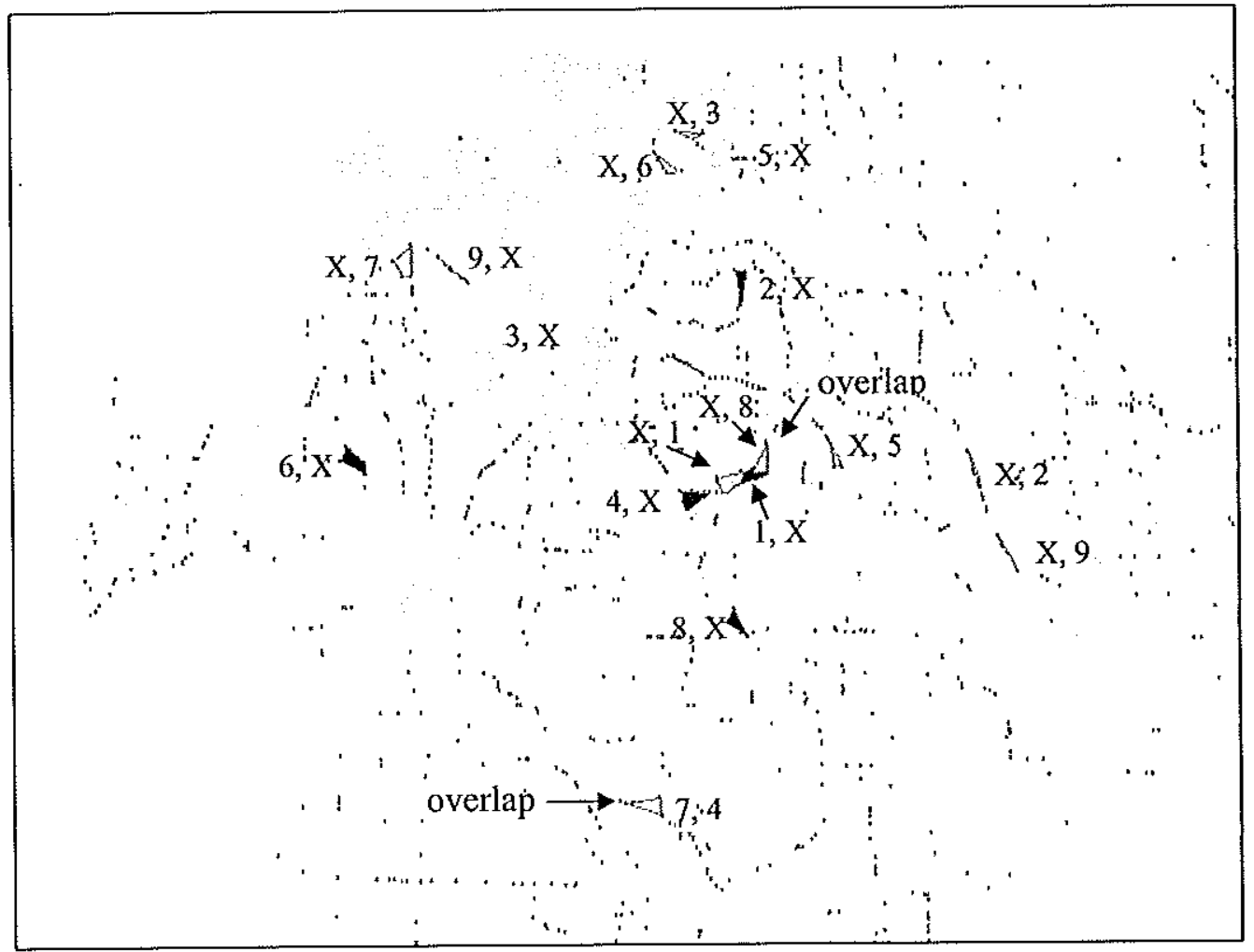

Figure 18. Rut/hunt (black) and nonrut/nonhunt (gray) DVA hotspots showing two areas of seasonal overlap, Clackamas County, 1997-2004. First number $=\mathrm{rut} / \mathrm{hunt}$ hotspot identification number. Second number $=$ nonrut/nonhunt hotspot identification number. $\mathrm{X}=$ no hotspot. 
Table 19. DVA hotspot cluster identification number and number of DVA in cluster for nonrut months (December-August) and for rut months (SeptemberNovember) from Clackamas County carcass pickup reports, 1997-2004.

\begin{tabular}{llll}
\multicolumn{2}{c}{ Nonrut/Nonhunt } & \multicolumn{2}{c}{ Rut/Hunt } \\
$\begin{array}{l}\text { Cluster } \\
\text { I.D. \# }\end{array}$ & $\begin{array}{l}\text { \# of DVA } \\
\text { in Cluster }\end{array}$ & $\begin{array}{l}\text { Cluster } \\
\text { I.D. \# }\end{array}$ & $\begin{array}{c}\text { \# of DVA } \\
\text { in Cluster }\end{array}$ \\
\hline 1 & 15 & 1 & 16 \\
2 & 15 & 2 & 13 \\
3 & 15 & 3 & 13 \\
4 & 14 & 4 & 12 \\
5 & 13 & 5 & 12 \\
6 & 12 & 6 & 12 \\
7 & 12 & 7 & 12 \\
8 & 11 & 8 & 11 \\
9 & 11 & 9 & 11
\end{tabular}

\section{Landscape Characteristics of DVA Hotspots}

I identified the landscape and road characteristics of the 19 largest DVA hotspots by layering a GIS shapefile of hotspots over 10' resolution orthophotographs of their surrounding landscape. A visual search identified landscape characteristics that are predictive factors of hotspots in literature DVA hotspot models for the whitetailed and mule deer (Table 20, Appendix F). All roads with hotspot segments traversed areas with scattered residences in a mosaic of agricultural fields and dense forest vegetation. The two Sunnyside Road hotspots are in high development areas. 
Eighty-nine percent of hotspots had road segments that intersected or paralleled streams. One hundred percent of hotspots intersected or were adjacent to large forested areas or dense vegetation. Portions of $95 \%$ of road segments with hotspots lie on a forest-field boundary, separating cover from food. Ninety-five percent of hotspots lie on roads with long in-line visibility; only $5 \%$ lie on roads with short inline visibility (Table 20, Apppendix F).

Table 20. DVA hotspot model factors and their presence in the 19 largest Clackamas County DVA hotspots.

Model Factor

Percent of

Hotspots

Where Present

\section{Land Use}

- $\quad$ scattered residences 100

- man-made corridors directing deer to road 89

\section{Landscape}

- road intersects or parallels riparian corridors/wetlands $\quad 89$

- road adjacent to or intersects large wooded areas 100

- area is mix of forest and fields 100

- road separates forest and field 95

\section{Visibility}

- road has long in-line visibility 95

- road has short in-line visibility (sinuosity) 5

- dense vegetation approaches road on one or both sides 89 


\section{Vehicle Speed, Traffic Volume, and Road Class of DVA Hotspots}

I determined vehicle speed, traffic volume, \% truck traffic, and road class for the road segments with the 19 densest DVA hotspots, for January and November of 1997 , and January and November of 2002 (Appendix G). Vehicle speed ranged from 39-63 mph. Eight hotspots decreased or showed no change in traffic speed over the study period with five sites increasing; data was unavailable for 6 hotspots (Appendix G). The average speed in the study was $60 \mathrm{mph}$ (with 6 unknowns) for drivers in the 85 th percentile in 1997 and $54 \mathrm{mph}$ in 2002 (with 1 unknown). Traffic volume increased in 7 hotspots and decreased or showed no change in 10 hotspots (with 2 unknowns).

With the exception of the three hotspots on Sunnyside and Stafford Roads, traffic volume was relatively low on roads with DVA hotspots, ranging from $670 \mathrm{ADT}$ to 7,000 ADT (Appendix G). Percent truck traffic ranged from $2.1-11.2 \%$ of total traffic in 1997 and from $2.6-15.1 \%$ in 2002 . The percent truck traffic average was $7.5 \%$ (with 6 unknowns) in 1997 and $10.0 \%$ (with 1 unknown) in 2002 . Hotspot road classes included 6 major arterials, 9 minor arterials, 3 collectors and 1 unknown in 1997 with all roads except Harding Road (changed from collector to local) remaining in the same road class in 2002 . 


\section{CHAPTER 5}

\section{DISCUSSION}

\section{Temporal Patterns of Deer-Vehicle Accidents}

Clackamas County deer carcass pickup records indicate annual DVA increased $121 \%$ between 1997 to 1999 followed by a $26 \%$ decline by 2004 . These changes in DVA appear related to opposing local and regional changes in the fringe development of the Portland metropolitan area and changes in the transportation network and urban and rural landuse. DVA increases between 1997-2000 appear related to: 1) human population growth, 2) an increase in the number of rural commuter estates and the average daily trip, 3) deer migration out of the Cascade foothills into the Willamette Valley where forest recovery and landuse changes have influenced food supplies, and 4) the slow acclimation of deer to increased traffic volume on roads intersecting rural and wild habitat.

The subsequent decline in DVA between 2001 and 2004 may be a response to several factors including: 1) housing and land development driving deer populations eastward and southward and destroying fawning habitat, 2) a decline in average daily trip distance as fuel costs increased in 2001,3) decreased deer populations caused by DVA, 4) year-round deer hunting permits to prevent agricultural damage, and 5) the growth of coyote populations and increased fawn predation. 
Population in Clackamas County increased $\approx 11 \%$ from $1996-2004$, and $27 \%$

from 1990-2003. Population in unincorporated and primarily rural areas of the county increased $14 \%$ during the latter period. Fifty percent of residents work outside of the county suggesting an increase in miles driven. Vehicle miles traveled on state-owned highways increased more than 11\% from 1996-2004. Indirect measures of miles driven per day by county residents are inconclusive but are implied by the nearly $11 \%$ population increase in Clackamas County between 1996 and 2004.

The number of registered vehicles in the County increased $43 \%$ in the ten year period from 1996 to 2004 and may have contributed to DVA during the study period. The number of registered drivers however, rose by only $0.13 \%$ from $1997-2004$. Zoning in Clackamas County may also have an influence on miles driven. Clackamas County requires a minimum lot size of two acres that promotes the development of commuter ranchettes in areas previously zoned agricultural and wild lands (Skidmore, personal communication, 2002). This form of low density development increases daily commuting distance to work, school, and shopping and therefore traffic volume on the secondary arterials of this study.

\section{Seasonal DVA Patterns}

Both Clackamas County carcass pickup reports and ODOT deer-vehicle accident reports show strong seasonal variation in DVA coincident with the life-cycle of black-tail deer. Monthly carcass pickups for all years were lowest January-April with a small peak in March. Carcass pickups increased in May and peaked in October 
and November before declining abruptly in December. These results are similar to those reported for the white-tailed deer in the mid-western and eastern United States.

Vegetation growth along highway rights-of-way draws deer to roads.

Carbaugh et al.'s 1975 study of the distribution and activity of white-tailed deer along an interstate documents high deer presence along the highway in March-May and a much larger number observed in October-December. These authors suggest that local DVA patterns were in response to the greater availability of forage on highway rightsof-way in fall and spring when woodland forage is scarce.

Young deer crossing roads without their dams may contribute to the late spring DVA peak. Puglisi et al. (1974) noted an increase in white-tailed male deer mortality during May and June which they speculate was caused by the abandonment of yearling males by their dams at this time. Dasmann and Taber (1956a) and Miller (1974) report that black-tailed does chase yearlings of both genders away from bedded fawns. Geist (1981) confirms this behavior in mule deer. An increase in the testes weight of bucks coincident with summer antler development occurs during this time period (Allen and McCullough 1976). These physiological changes may cause restlessness in bucks that could account for the increase in highway fatalities during late May (Robinson 1965).

Allen and McCullough (1976) found white-tailed deer-vehicle accidents peaked in mid-November, corresponding to the peak of the rut and closely following the opening week of deer hunting in southem Michigan. They further found a secondary, spring increase in DVA during May, a result confirmed by Reilly and Green (1974). Hubbard et al. (2000) found that DVA involving white-tailed deer were 
highest in May and November, corresponding to spring dispersal, female movement to fawning grounds, and the peak of the rut.

Hindelang et al.'s (1999) research on white-tail deer also show peak DVA in November with $>50 \%$ of anmual total accidents occurring in October, November, and December. Similar results are noted by other researchers. Jahn (1959) and Bellis and Graves (1971) note high mortality in spring and fall and low mortality in winter and summer with the November kill high for white-tailed deer. Allen and McCullough's 1976 study of white-tailed deer showed that the major peak in DVA occurred in the fall and was most likely attributable to the rut. Forty-three percent of all northwest Clackamas County DVA occurred during the rut months of September, October, and November.

Studies indicate that deer hunting increases DVA. Puglisi et al. (1974) found white-tailed deer mortality peaked during October, November, and December, and attributed it to movement during breeding season and to the disturbance of deer by fall hunting season activities. Peek and Bellis (1969) found that deer numbers declined in their study area during deer hunting season when hunters walk along the highway. Carbaugh et al. (1975) found fewer deer along the highways during hunting season when hunters walk along the right-of-way and stage hunting drives in nearby wooded areas. Romin and Bissonette (1996a) determined that highway mortality of mule deer in Utah generally peaked during fall in conjunction with breeding and hunting seasons. Dasmann and Taber (1956) describe the confusion and panic of young male blacktailed deer during the opening of the hunting season. 
In Clackamas County, Monthly Traffic Conversion Factors verify that people drive more during favorable weather, with traffic volumes peaking during the summer months, and lowest in the period, October- March. Traffic volumes consequently appear to be inversely related to the DVA peak in Clackamas County, suggesting that traffic volume is not responsible for seasonal fluctuations in DVA. Allen and McCullough (1976) and Hindelang et al. (1999) found a similar lack of correlation between traffic volume and DVA volume for white-tailed deer in Michigan and attributed fall DVA peaks to deer activity and behavior.

The proportion of total annual DVA occurring during the rut/hunt months is an important factor in selecting and siting an appropriate DVA mitigation option. Rut and hunt factors loom large in the high DVA rate for September-November. Seasonal DVA variation should be considered in identifying animal movement corridors and designing mitigation because of the less predictable behavior of deer during the rut

and hunting seasons. Conversely, resident deer might benefit by travel corridors based on non-rut and non-hunt months when deer remain in their home ranges with more predictable travel routes. Determination of the stability of deer travel routes during rut/hunt months remains an important research question regarding the potential location of mitigation structures.

\section{Day-of-Week DVA Patterns}

Human and deer activity patterns may produce day-of-week DVA patterns. Weinman (personal communication, November 2005) reports heavy recreational travel 
in Clackamas County on Friday evening and Saturday, especially in winter. My results show low DVA on Friday and Saturday during the winter suggesting deer are relatively inactive. Conversely, high DVA occurred on Saturdays in June, July, and September when both deer and people are active (Figure 11). These latter results are similar to Allen and McCullough (1976) finding that number of DVA was highest on weekends when traffic was concentrated during the evening and night time hours when deer are active.

\section{Daily DVA Pattern}

The two daily DVA peaks noted for Clackamas County coincide with the daily activity patterns of black-tailed deer and humans, and are similar to patterns reported for the white-tailed deer in the mid-western and eastern United States. Hindelang et al.'s 1999 study of Michigan white-tailed deer found that peak white-tailed deervehicle crashes occurred between 0500 and 0800 and between 1800 and 2300 hours. This pattern was also noted by Allen and McCullough's (1976) study of white-tailed deer and Groot Bruinderink's and Hazebroek's (1996) study of roe deer in the Netherlands.

The black-tailed deer is reclusive, hiding during the day, emerging at dusk from cover to feed, and returning to cover at dawn. These behavioral characteristics are similar to those reported for white-tailed deer (Peek and Bellis 1962, Montgomery 1963, Progulske and Duerre 1974, Carbaugh et al. 1975). My results show that $83 \%$ 
of DVA occurred during the dark hours between sunset and sunrise, and $17 \%$ of total DVA occurred during the light hours between sunrise and sunset.

My results reveal the a.m. DVA peak occurs earlier than 0700 and the p.m. DVA peak extends several hours beyond Weinman's (2005) estimates of rush hour periods in Clackamas County as $0700-0800$ and $1630-1830$. These differences may reflect the location of most DVA on county-maintained roads outside of the urban areas and some distance from the major arterials. Travel time to work may force rural residents to leave home earlier and return later, and this may be captured in the extended DVA peaks.

DVA peaks require the presence of both vehicles and deer. Some studies suggest that DVA peak when dawn and "dusk +2 hours" overlap morning and evening rush hour, the periods when deer and vehicles are present on roads in highest numbers. In my study, $21 \%$ of DVA occurred when pre-dawn and dusk +2 hours overlapped a.m. and p.m. rush hours, a significant percent because these periods constitute only $9.8 \%$ of annual hours. The highest DVA period of the day is dusk +2 hours, accounting for $42 \%$ of total DVA in $19 \%$ of total annual hours.

\section{Deer-Velicle Accident Hotspots}

Deer of all species regularly cross low traffic volume roads during routine daily movements within an established home range. Although deer are neither obligate crepuscular nor nocturnal, they are shy of humans and shun open areas during daylight hours (Putnam and Mann 1990). Most crossings occur at night with peaks at 
dawn and dusk as animals move to and from feeding areas lacking cover. In wellwooded areas, crossings may occur at any time of day or night (Putnam 1997).

Carbaugh et al. (1975) note that the relationship between deer activity and deer-automobile collisions is a function of highway location relative to deer requirements such as feeding and resting sites, and relative availability of feeding areas other than rights-of-way. If the highway is located between wooded areas where deer bed during the day and agricultural areas where deer feed during the night, deer have strong tendencies to cross lanes of traffic. Romin and Bissonette (1996a) found that deer often move parallel along the right-of-way after approaching a road, making it impossible to predict precisely where DVA will occur based on habitat and topography adjacent to or near roads.

Bellis and Graves (1971) note that deer that habitually cross a road may become more wary. Many deer must have experienced near-misses and injuries that possibly influenced subsequent highway-crossing behavior.

Deer road-crossing behavior may also be explained by the evolution of behavioral traits that reflect local habitat conditions and changes in these conditions in response to human activities. In southwest Washington and east of the Cascade crest, black-tailed deer are more social and often seen in groups in grassland and open woodlands areas. West of the Cascade crest, where deer behavior developed in the presence of forest cover (Bender 2000), black-tailed deer are reclusive and prefer to approach open areas such as roads under cover.

In northwestern Clackamas County, the relatively dense human and pet populations constrain black-tail deer to areas of dense cover where they can hide 
during the day and find safe sites for bearing and raising their young. White-tailed deer prefer to move between bedding and feeding sites along riparian corridors (Dusek et al. 1988), and this may also be true for black-tailed deer.

\section{Identifying Hotspot Locations in Clackamas County}

Wildlife crossing structures are an effective form of DVA mitigation where roads disrupt major wildlife movement corridors and create DVA (Clevenger et al. 2001, Bank et al. 2002, Dodd et al. 2003). Siting crossing structures in the direct path of movement corridors is critical. My results identify 12 discrete road/movement corridor intersections where vehicles frequently hit deer and $\geq 5$ DVA occurred between 1997-2004. These results only include incidents with identical x,y coordinates and represent a conservative estimate of potential crossing structure sites.

\section{Identifying DVA Density Along Road Segments}

The literature indicates that DVA often cluster along road segments rather than occurring randomly. The fuzzy mode clustering routine identified three categories of DVA density on northwest Clackamas County Roads. Identification of road segments and the spatial distribution of DVA along road segments is an important component in the selection of an appropriate mitigation option. A crossing structure with fencing

may be an appropriate mitigation solution for densely clustered DVA. A warning sign or public education may be a more appropriate mitigation option for DVA dispersed 
over a long segment of highway, including areas where roads run through large forest blocks (Bashore 1985). Northwestern Clackamas County has both concentrated and dispersed hotspots (Appendix F).

\section{Seasonal Shifts of DVA Hotspot Locations}

My results show hotspots are seasonal and that there is little overlap (28\%) between rut/hunt and non-rut/non-hunt hotspot locations. This, and the knowledge that $42 \%$ of all DVA occurred during the three rut/hunt months, has important ramifications in designing DVA mitigation. Deer crossing signs and lowered speed limits in these areas are ineffective because DVA occur so infrequently that the driving public becomes inured to the danger (Putnam 1997, Hedlund et al. 2004). Knowledge of the shorter critical periods for particular hotspots and provision of this knowledge through the nightly news, other forms of local information, and signage may be more effective in engaging public attention and response. For example, the public could be wamed "during the months of September, October, and November to exercise extreme caution, including lowered speed limit, when driving Henrici Road at dawn or after dark."

\section{Characteristics of Deer-Vehicle Accident Hotspots}

The literature describes a number of landscape, land use, road, and traffic characteristics of white-tailed deer-vehicle accident (DVA) hotspots. These 
characteristics are also common to northwest Clackamas County hotspots for blacktailed deer (Appendices F and G).

Buildings. Bashore et al. (1985) identified a negative correlation between the presence of deer and occupied buildings around DVA hotspots. High levels of human activity and loss of habitat reduce deer usage of sectors of highways occupied by buildings. Commercial buildings $\geq 50 \mathrm{~m}$ in length act as physical obstacles to deer attempting to cross highways. Finder et al. (1999) state that residential areas within wooded habitat may be refuges from hunting and, in their study, occurred in significantly greater numbers around hotspots than controls. All of the hotspots in this study were near scattered residences surrounded by agricultural fields, old fields, scrub, and forested areas, which makes good deer habitat. The two Sunnyside Road hotspots are emerging from this pattern through rapid development (Appendix F).

Natural and Human-Created Corridors. Development in the form of buildings may direct deer to road crossings. The 97th Street/Mather Road hotspot, located where apartment complexes constrict a green belt to a narrow corridor at the road crossing, may be an example of this. The Sunnyside Road/106-124th Avenue hotspot includes a segment where Sunnyside Road distupts a riparian corridor constricted on both sides by dense multi-unit development.

Among some animals, corridors act as drift fences that gather individuals moving through the landscape and funnel them along specific paths (Haddad and Baum 1999). DVA increase where these corridors intersect roads. Field edges may 
act as drift fences (Hubbard et al. 2000). Other features that funnel deer onto highways include riparian corridors, unimproved roads intersecting highways, and fences. Ridges descending to a road (Caldwell 2005), gullies/cuts, forest-field edges perpendicular to road, and hills grading into valleys (Peek and Bellis 1969, Hubbard et al. 2000) also funnel deer. Forest-field edges and unimproved roads perpendicular to and intersecting the roads of my study are common in the suburban-rural mix of this area (Appendix F).

Water Features. A number of studies indicate a positive correlation between hotspots and the presence of streams, wetlands, and other water bodies. Hubbard et al. (2000) note that there are more bridges near white-tailed deer-vehicle accident hotspots because bridges are associated with riparian travel corridors and habitat patterns. Large drainages intersected highways in $78 \%$ of designated kill zones in Romin and Bissonette's (1996a) study of mule deer in Utah. Finder et al. (1999) state that riparian corridors crossing roads may influence deer movement patterns. Their study of white-tailed DVA showed that the probability of a road/riparian corridor intersection being a high DVA site increased with the width of the riparian corridor. My study determined that in $89 \%$ of hotspots in Clackamas County, at least one riparian corridor intersected or paralleled the road. Riparian corridors both intersect and parallel the Union Mills Road hotspot (Appendix F).

Woodland-Field Interfaces. Bashore et al. (1985) determined that woodlandfield interfaces close to the highway were high DVA zones because deer remain close 
to woods while feeding on grasses and other herbaceous vegetation. Areas where the highway lies on the woodland-field interface may also be DVA hotspots as the highway separates cover from food and forces the deer to cross it several times in each 24-hour period (Carbaugh et al. 1975). Segments of $95 \%$ of the hotspots in my study separate forest and field. The Springwater Road hotspot at Feldheimer Road (Appendix F) lies on such a forest/field boundary.

Allen and McCullough (1976) determined that the occurrence of white-tailed DVA is proportional to the prevalence of crop, unimproved field, and forest habitat, and that a large number of DVA occurred near crops or fields. Many studies indicate that deer need both cover and forage in close proximity (Kremsater and Bunnell 1992, Chang et al. 1995, Boroski et al. 1996, McCorquodale 1999). This mix of forest and field exists along segments of $100 \%$ of the hotspots I identified in Clackamas County.

Forested Areas. Wooded areas with cores $\geq 50 \mathrm{~m}$ from the perimeter are good fawning and hiding areas for deer (Hubbard et al. 2000). Finder et al (1999) determined that the inverse of the distance from roads to forest cover is the most important predictor of high DVA. Allen and McCullough (1976) determined that DVA in southern Michigan are most common in areas where forests are more prevalent. Deer distributions in Illinois are also primarily dependent on the presence of forest cover (Roseberry and Woolf 1998).

Deer remain close to forest cover when foraging or moving to or from an area (Carbaugh, 1970). In Witham's (1990) study, public recreation land within a $0.8 \mathrm{~km}$ radius of road segment increased the probability of DVA, probably by contributing to 
local deer abundance by providing refuges from hunting, wooded habitat or food plots, all of which elevate deer densities.

Northwest Clackamas County is developing rapidly but large forested areas with cores $\geq 50 \mathrm{~m}$ are common, especially on the more difficult-to-develop hill slopes. These make excellent fawning areas. Often, hotspots occur where roads run through the middle of these areas or separate these areas from smaller forested blocks which may provide enough cover for a mobile adult deer, but not for new fawns. Does retuming to these larger blocks in spring to fawn are forced to cross these roads.

All the study hotspots intersect or lie adjacent to large forested blocks. Examples include the Sunnyside Road/106-124th Avenue hotspot where Sunnyside separates the large forested core of Mt. Talbert from the green corridors to the north, and the 97th Ave./Mather Road hotspot where Mather Road separates Mt. Talbert from the green corridors to the south. A large forested block lies southwest of the Rosemont Road hotspot. The Union Mills Road hotspot and the Henrici Road hotspot lie between large blocks of densely forested land, which deer may be moving between (Appendix F).

Wooded habitat on both sides of a road may also identify potential high DVA areas (Nielsen et al. 2003, Bashore et al. 1985). Allen and Mccullough (1976) determined that DVA in southern Michigan are most common in areas where forests are more prevalent. However, Bellis and Graves (1971) found few high kills sites occurred along an interstate highway bordered by forests and most deer were killed at randomly spaced sites. Bashore et al. (1985) determined that in many wooded areas no distinct concentrations of accidents could be discerned. Instead, kills were 
distributed throughout the area, suggesting that a motorist could expect to encounter a deer crossing almost anywhere. Many of the hotspots in this study are long with dispersed DVA, though 17 of them have a segment that contains $\geq 10$ DVA within a 0.25 mi search radius, and 4 of them have a segment that contains $\geq 10$ DVA within a 0.125 mi search radius (Appendix F).

\section{Visibility}

The visibility along and to the side of a road is a factor contributing to DVA among white-tailed deer (Finder et al. 1999, Bashore et al. 1985). Shrubby or wooded vegetation adjacent to the road enable deer to approach and enter the road without being seen, providing little time for a driver to avoid a collision (Appendix F). Shortdistance visibility resulting from road sinuosity or elevation changes may be a factor in DVA hotspots as a deer may be standing in the highway just around the curve (Appendix F). Long in-line visibility, where the road has long, straight stretches, may be a factor if drivers drive faster on these stretches of road, increasing their stopping distance (Appendix F).

Bashore et al. (1985) determined that short-line visibility is negatively related to the probability of vehicle-deer accidents, and that drivers avoid hitting deer if they are seen in advance. Finder et al. (1999) found no significant different in road sinuosity between hotspots and controls, but speculated this was the result of three possible factors: 1) sinuosity does not affect the DVA rate, 2) the positive and negative effects of sinuosity cancel each other out, or 3) measurements at hotspot and controls may 
have been spatially autocorrelated because of their proximity. The Henrici Road hotspot has many curves and elevation changes.

Long, straight, flat stretches of road also promote high visibility and high DVA rates. When drivers can see a considerable distance down the road, they travel at high speed and may strike a deer crossing the highway from a blind spot. Drivers often claim that they never saw the deer until it moved onto the highway (Pojar 1975, Case 1978, Bashore et al. 1985). Ninety-five percent of the hotspots in this study occur on roads that have long, straight stretches. Examples include the Springwater Road, Harding Road, Spangler Road, and Redland Road hotspots (Appendix F). These results indicate that DVA are more likely to occur on long, straight road segments, which promote high vehicle speeds, than on roads with high sinuosity.

\section{Vehicle Speed, Traffic Volume, and Road Class}

Several studies indicate that the relationship between vehicle speed, traffic volume, road class and number of DVA is complex. In Pennsylvania, more DVA occurred along 2-lane roads than interstates (Bashore et al. 1985). Hindelang et al (1999) determined that deer-vehicle crashes tend to occur more frequently on two-lane

rural roads. Seventy percent of the accidents in Allen and McCullough's 1976 study occurred on paved roads of two or more lanes that were not divided highways. Hubbard et al. (2000) found high DVA were positively associated with number of traffic lanes. A majority of the hotspots in this study occur on two-lane roads, but that may reflect the study's reliance on two-lane county road data. The lack of carcass 
pickup information for state and federal highways in the study area made the relationship between number of lanes and DVA impossible to explore. Hotspots in northwest Clackamas County occurred on a variety of road classes, including major and minor arterials, collectors, and one local (Appendix G).

Hubbard et al. (2000) found high DVA were not positively associated with traffic volume. Groot-Bruinderink and Hazebroek (1996) state that the effects of changes in traffic volume or in ungulate numbers on the number of road kills are often ambiguous. Others (e.g., Romin and Bissonette 1996a, Finder 1998) find traffic volume significantly influenced overall deer mortality levels. Traffic volume, in general, increased $11 \%$ in Clackamas County during the study period. Traffic count studies for County-maintained roads indicate that traffic volume increased from 1997 . 2002 on 7 out of 19 major study hotspots, decreased in 7, remained unchanged in 3 , and data was unavailable for 2 hotspots. With the exception of the Sunnyside and Stafford Road hotspots, traffic volume was relatively low on roads with DVA hotspots, ranging from 765 ADT to 7,000 ADT (Appendix G). The relationship between traffic volume and DVA is ambiguous in this study.

Bashore et al. (1985) state that posted speed limit showed a significant negative correlation with deer kill probability, possibly because fewer deer cross highways where vehicles move rapidly or, more likely, the posted speed limit has little relationship to actual vehicle speed. Allen and McCullough (1976) noted that $50 \%$ of DVA occurred in the 80-95 $\mathrm{kmh}$ speed range (50-60 mph) and suggest that imposing lower speed limits may not decrease DVA. Traffic count studies for Clackamas County, 1997-2002, show that 85 th percentile vehicle speed decreased on 6 study 
hotspots, remained unchanged in 2 , increased in 5 , and was unavailable for 6

hotspots. The average monitored vehicle speed in the study hotspots was $96 \mathrm{kmh}$ (60 mph) (with 6 unknowns) in 1997 and $86 \mathrm{kmh}$ (54 mph) (with 1 unknown) for drivers in the 85 th percentile, meaning that, on average, $15 \%$ of drivers drove above these speeds (Appendix G). The relationship between DVA hotspots and vehicle speed is ambiguous in this study. 


\section{CHAPTER 6}

\section{CONCLUSIONS}

This thesis examined the spatial and temporal patterns of black-tailed deervehicle accidents (DVA) on county-maintained roads in the suburban/rural landscape of northwest Clackamas County, Oregon. Using 1,880 Clackamas County Road Department carcass pickup reports for 1997-2004 and 717 Oregon Department of Transportation (ODOT) deer-vehicle accident reports for 1996-2004, I specifically sought to address the following research directives:

- Identify the daily, weekly, seasonal, and annual DVA cycle

- Relate daily DVA cycle to sunrise, sunset, morning rush hour, and evening rush hour

- Relate daily and seasonal DVA cycles to black-tailed deer daily and seasonal cycles

- Identify DVA hotspots in northwest Clackamas County

- Determine percentage of DVA that occur within hotspots and outside of hotspots

- Examine the seasonal shifts of DVA hotspot locations

- Relate the literature-described landscape, road, and traffic characteristics of DVA hotspots to selected Clackamas County DVA hotspots 


\section{Temporal DVA Patterns}

\section{Population Growth and Development}

Trends in deer carcass pickups between 1997 and 2004 correspond to recent changes in human and black-tailed deer demographics in Clackamas County. Human factors that indirectly promoted DVA during the study period include an $11 \%$ population increase from in Clackamas County between 1997-2004 and the construction of 9,900 units of private single and multi-unit residences from 20002004. The popularity of ranchettes and minimum lot sizes of 2-90 acres outside urban areas promoted rapid, dispersed development in previously rural lands, affecting deer habitat and resource availability, and the number of vehicle trips. Registered vehicles increased by $43 \%$ and annual vehicle miles driven in the County by $11 \%$. Construction of 70 miles of city-owned roads (miles of state- and county-owned roads remained constant) may also have increased DVA. Rising gas prices causing County residents to drive fewer miles beginning in 2000 may have contributed to the DVA decline beginning in 2001 (carpenter, personal communication, November 2005).

\section{Factors Influencing Black-Tailed Deer Populations}

Several factors influencing local deer populations appear to have contributed to the fluctuating numbers of DVA incidents along the urban/rural fringe. Increasingly, deer are moving into the Willamette Valley in response to land use changes, including 
a decline in logging and a subsequent reduction in food supply on BLM and USFS public lands in Clackamas County. This has resulted in growing deer populations in the Willamette Valley, as well as subsequent growth of the coyote population (May 1996; Cottam et al. 2003; Caldwell, personal communication, November 2005). Coyote predation, coupled with the loss of viable fawning sites following development, may be partially responsible for local deer population declines since 1999.

Deer migration, population fluctuations, and the temporal patterns of DVA may also be influenced by human hunting. The western Oregon black-tailed deer population is declining, and ODFW's Black-tailed Deer Work Group cites extermination of deer populations forced into agricultural areas for food as one cause (Cottam et al. 2003). Oregon Department of Fish and Wildlife (ODFW) does not manage local deer populations but issues year-round emergency hunting permits in the County to reduce deer damage to agricultural crops (Caldwell 2005).

Highway construction and initial use influence temporal patterns of deervehicle accidents. Research by Reilly and Green (1974) show initially high DVA after the opening of a new highway, followed by a decline as local deer populations and family groups are eliminated. This may be a contributing factor to the decrease in DVA after 2000 in Clackamas County as roads with hotspots existed before 1997. The lack of new county road construction during the study period may be another factor. This DVA decline suggests vehicles have killed many deer living along these roads, or deer have acclimated to the road (Reilly and Green 1974). 


\section{Seasonal DVA Pattern}

Monthly carcass pickups, consolidated for all years between 1997 and 2004, were lowest in the period, January-April. Number of pickups began to rise in May. Following a decrease in carcass pickups in August, DVA rose to their highest frequency in October and November before declining abruptly in December. This pattern was evident in Clackamas, Washington, and Multnomah Counties, and is similar to that reported in the literature for white-tailed and mule deer.

Seasonal DVA patterns appear strongly related to the black-tail's annual cycle. Black-tail activity increases in spring in response to the emergence of spring grasses. Does return to fawning areas in May, and young bucks separate from their dams in June and July. Does with fawns re-emerge from hiding in July. Rutting activity begins in September and continues through November, with recovery during winter months. Forty-two percent of DVA occur during the September-November rutting period. Traffic volume decreases during the fall period indicating it was not responsible for this pattern.

Several studies documenting a similar pattern among white-tail and mule deer support the hypothesis that DVA are strongly related to deer activity in response to rutting behavior and hunting pressure. Both genders and all ages of deer increase activity during the rut. Females may elude males and young male deer mimic the behaviors of older deer. During the hunt, young deer commonly panic and rush about wildly, crossing roads carelessly. Based on white-tailed deer research, black-tail deer 
may also be reluctant to occupy home ranges vacated by other deer (Porter et al. 1991).

\section{Daily DVA Pattern}

Daily DVA incidents for Clackamas County show two daily peaks of deer activity on roads. DVA began to rise at 0300 , peaked at 0500-0700, and dropped off sharply at 0700 . DVA were low throughout the day until 1700 when they began to rise again, peaked at 1800-2200, and dropped off at 2200. DVA incidents for Washington and Multnomah Counties showed similar patterns and correspond to the DVA patterns documented for the white-tailed deer.

DVA in Clackamas County broadly correspond to traffic volume. Some literature indicates that DVA peak when dawn and "dusk +2 hours" coincide with morning and evening rush hours. My results show $\approx 21 \%$ of annual DVA occurred when dawn and "dusk +2 hours" coincided with morning and evening rush hour, $\approx 10 \%$ of total annual time. Annual summaries of weekday DVA occurrences for 1996-2004 indicate that DVA rose slowly during the week, peaking on Fridays when there may be greater human evening activity levels

\section{DVA Spatial Patterns}

Three statistical clustering techniques (CrimeStats III) identified several DVA spatial patterns. The mode routine identified 224 locations of unique $\mathrm{x}, \mathrm{y}$ coordinates 
at which more than one DVA had occurred. The fuzzy mode routine using a search radius of $0.5 \mathrm{mi}$, calculated DVA frequency within a $0.5 \mathrm{mi}$ search radius for each DVA. The frequency distribution of results indicated data breaks between DVA at frequencies of 7 and 8 , and 15 and 16 DVA, indicating certain factors or combination of factors create thresholds influencing DVA occurrence.

The nearest neighbor routine identified 19 major hotspots with $\geq 16$ DVA and numerous smaller ones. A circular search radius of 0.5 mi occasionally picked up extraneous DVA whereas a smaller search radius $(0.25 \mathrm{mi})$ identified fewer clusters with at least 10 DVA. The nearest neighbor routine run on DVA in rut months (September-November) and non-rut months (December-August) indicated that hotspot locations change on a seasonal basis.

The 19 densest DVA hotspots shared many of the characteristics described in the literature for hotspots involving white-tailed and mule deer. Eighty-nine percent occurred where the road intersected or paralleled at least one riparian corridor or other water feature. All were located in close proximity to or intersected a large forest block, good fawning and hiding habitat. All were located among scattered residences. All hotspots occurred in areas with a mix of field and forest. Most hotspots occurred on two-lane highways. Several occurred where dense development restricted the deer movement corridor to a narrow band where it intersected the road. Most had long, straight stretches of road, which encourages in drivers a false sense of security and promotes speeding. 


\section{Recommendations}

\section{Maintain Carcass Pickup Reports with GPS Location}

Carcass pickup reports provide an inexpensive source of data useful for the mitigation of deer-vehicle accidents. Alternative tracking of DVA includes the more expensive procedure of collaring and tracking. Clackamas County Road Department maintains excellent carcass pickup records but ODOT, which maintains state and federal highways, and most of the city governments which maintain city roads, do not keep carcass pickup records. This is a lost opportunity to obtain useful yet inexpensive data. The frequency and consequences of deer vehicle accidents in Clackamas County are sufficient to recommend that all agencies that retrieve wildlife carcasses from roads maintain records.

Carcass locations should be recorded using the Global Positioning System (GPS) and should include the date of pickup, species, gender, and approximate age. This information is easily downloaded to a database. A centralized database for the Portland metropolitan region could be created from all these sources and provide excellent, inexpensive data regarding wildlife movement corridors within the region. DVA locations recorded by GPS would be more precise than those used in this study, which relied on dispatcher's and the reporting public's descriptions.

Precision of data is important when designing mitigation. This information could be used for locating crossing structures and fencing to mitigate DVA incidents. This information could also be used to substantiate the need for mitigation in applying 
for the federal funding that is available through The Transportation Equity Act for the 21 st Century (TEA-21). The Western Transportation Institute has designed a roadkill data collection system for road maintenance personnel. The system consists of a pocket-size personal computer (PC) with a GPS unit and a software program that records a GPS reading for the DVA location as well as all of the above information. It is automatically downloaded to a PC when the PDA is synchronized, and conventional statistical (EXCEL) and mapping programs (ARC-GIS) can be used to analyze the information (Western Transportation Institute 2005).

The Wildlife Accident Reporting System (WARS) of British Columbia is an excellent model for regions that want to record and monitor their wildlife-vehicle collisions. The British Columbia Ministry of Transportation (BC MoT) administers this system that collects and analyzes wildlife-vehicle accident data collected by MoT Maintenance Contractors on selected highways in B.C. (British Columbia Ministry of Transportation 2006).

\section{Public Education and DVA}

Thirty-five percent of all DVA occurred within hotspots having ten or more DVA; sixty-five percent of all DVA occurred outside of these hotspots. These results present two contradictory challenges for transportation and wildlife managers. DVA associated with hotspots can be mitigated through modeling and the development of wildlife crossing structures and fencing. Wildlife crossing structure projects in 
Portland, Oregon, the U.S., and Canada are numerous and provide useful examples for transportation and wildlife managers.

- The underpass carrying Mt. Scott Creek under Sunnyside Road at approximately S.E. 117th in Clackamas County.

- The underpass carrying Kelly Creek under S.E. Foster Road at S.E. Dahlquist Rd in Multnomah County.

- The I-90 Snoqualmie Pass East project that will establish ecological connectivity across I-90 northern Washington for animals, plants, soils, water, and wind.

- Black bear undercrossings on State Route 46 in Lake County, Florida

- Underpasses, culverts, and overpasses for large and small mammals, reptiles, mammals, and fish that will reunite the two halves of the Flathead Reservation separated by U.S. 93 between Evaro and Polson, Montana

- Underpasses, culverts, and overpasses for wildlife across the Trans Canada Highway from Banff National Park's East Gate to Castle Junction, Alberta.

Hotspot models predicting locations for potential DVA are currently available for white-tailed and mule deer and are probably applicable to the black-tailed deer based on their similarities in seasonal and daily activities. One issue in applying white-tailed and mule deer models to black-tailed deer is that many of these models were developed in areas where deer must migxate to survive winter. The black-tails in Clackamas County are residential because of the locally mild winters.

Hotspot models should routinely be employed in siting and designing roads so that hotspots are never created. During highway planning, proposed sites should avoid 
areas with large forest blocks, riparian corridors, and forest/field edges. In planning new roadways, DVA can be mitigated by creating opportunities for deer to pass under roadways that intersect streams and wherever bridges are being built. Underpasses have been shown to be effective travel corridors for deer and other wildlife.

DVA occurring outside of hotspots require public education. DVA have a seasonal and a daily pattern, and animal movement corridors can be located by recording DVA locations. This information should be made available to the public so that drivers exercise caution when driving roads that disrupt animal movement corridors such as streams and greenbelts, especially just before dawn and after dusk, and during the rut and hunting months of September, October, and November. Many studies indicate that volume of DVA is positively correlated with vehicle speed. Slower speeds give drivers more time to react appropriately to deer on roads or at the side of roads.

The Wildlife-Vehicle Accident Prevention Program (WVAPP) of the British Columbia Conservation Foundation (BCCF) is an excellent model for public education of both drivers and highway managers. BCCF's website (http://www.wildlifeaccidents.ca) provides information on the reasons why wildlife frequent roads, time of day and season when drivers are most likely to encounter particular species, and appropriate driver responses to animals on or entering roads. This website also provides information for highway managers on mitigation methods, conferences, newsletters, and other educational opportunities. $\mathrm{BCCF}$, in partnership with public agencies and private corporations, also funds educational kiosks in roadside rests, highway billboards, and a public awareness brochure. 


\section{REFERENCES}

Allen, R.E. and McCullough, D.R. 1976. Deer-car accidents in southern Michigan. Journal of Wildlife Management 40:317-325.

Bank, F. G., Gray, M. E., Paulson, D., Irwin, C. L., Hagood, S., Ruediger, B., Evink, G. L., Kinar, J. R., Sauvajot, R. M., Levy, A. 2002. Wildlife habitat connectivity across European highways. Report No. FHWA-PL-02-011 from the International Technology Exchange Program. Federal Highway Administration. U. S. Department of Transportation, Washington, D. C.

Bashore, T.L., Tzilkowski, W.M. and Bellis, E.D. 1985. Analysis of deer-vehicle collision sites in Pennsylvania. Journal of Wildlife Management 49:769-774.

Bellis, E.D. and Graves, H.B. 1971. Deer mortality on a Pennsylvania interstate highway. Journal of Wildlife Management 35:232-237.

Bender, L.C. 2000. Relationships between social group size of Columbian blacktailed deer and habitat cover in Washington. Northwestern Naturalist 81:4953.

Bender, L.C., Anderson, D.P., and Lewis, J.D. 2004a. Annual and seasonal habitat use of Columbian black-tailed deer in urban Vancouver, Washington. Urban Ecosystems 7:41-53.

Bender, L.C., Lewis, J.C., and Anderson, D.P. 2004b. Population ecology of Columbian black-tailed deer in urban Vancouver, Washington. Northwestern Naturalist 85:53-59. 
Boroski, B.B., Barrett, R.H., Timossi, I.C., and Kie, J.G. 1996. Modeling habitat suitability for black-tailed deer (Odocoileus hemionus colımbianus) in heterogeneous landscapes. Forest Ecology and Management 88 (Special Issue): $157-165$.

Boyd, R. 1999. Strategies of Indian burning in the Willamette Valley. In: Boyd, R. (ed.) Indians, Fire, and the Land in the Pacific Northwest (pp. 94-138). Oregon State University Press, Corvallis, Oregon.

British Columbia Conservation Foundation (BCCF). Wildlife -Vehicle Accident Prevention Program (WVAPP) [Internet]. [Cited December 28, 2005]. Available from http://www.wildlifeaccidents.ca/default.htm.

British Columbia Ministry of Transportation. Wildlife Accident Reporting System [Internet]. [Cited January 1, 2006]. Available from: http://www. gov.bc.ca/bvprd/bc/search.do?navID=NAV_ID_=8394\&action=searchresult $\& q p=\& n h=10 \& q \mathrm{t}=$ Wildlife $\% 20$ Accident $\% 20$ Reporting $\% 20$ System.

Bruinderink, G. and Hazebroek, E. 1996. Ungulate traffic collisions in Europe. Conservation Biology 10:1059-1067.

Budhabhatti, J., Price, J., Ruedas, L., and Anderson, L.K. 2002. Analysis of Vehicular-Wildlife Incidents from the Portland Metropolitan Area. U.S. Fish and Wildlife Conservation and Restoration Program Grant. Metro Regional Parks and Greenspaces. Portland, Oregon.

Caldwell, D. Personal Communication with Wildlife Biologist, Oregon Department of Fish and Wildlife, North Willamette Watershed District. Clackamas, Oregon. January 2005. 
Carbaugh, B., Vaughan, J.P., Bellis, E.D., and Graves, H.B. 1975. Distribution and activity of white-tailed deer along an interstate highway. Journal of Wildlife Management 39:570-581.

Carpenter, J. Personal Communication with Engineering Technician, Clackamas County Department of Transportation and Development, Sunnybrook Service Center. Clackamas, Oregon. November 2005.

Case, R.M. 1978. Interstate highway road killed animals: a data source for biologists. Wildlife Society Bulletin 6:8-13.

City-data. Clackamas County, OR Info [Internet\}. [cited December 18, 2005]. Available from http://www.city-data.com/county/clackamas_County-OR.html. Clackamas County GIS Division. Population by census tract based on 2000 census figures [On-Line Atlas]. Clackamas County, Oregon. [cited December 14, 2005]. Available from: http://www.co.clackamas.or.us/gis/images/census/2000jpg.

Clackamas County Overview [internet]. [cited December 14, 2005]. Available from: http://www.co.clackamas.or.us/about/overview.htm.

Clackamas County Transportation Maintenance. 2005a. Dead Animal Service Requests. January 1, 1997-December 31, 2004. Obtained from Shelly Leis, Microcomputer Programmer/Analyst, 2002 and 2004.

Clackamas County Transportation Maintenance. 2005b. Clackamas County road restoration program [Internet]. \{Cited December 20, 2005.\} Available from: http://www.co.clackamas.or.us/dtd/trans/info/roadlife.htm. 
Clackamas County Transportation and Development. 1998. 10' orthophotography of Clackamas County. Sunnybrook Service Center, Clackamas, Oregon. Clackamas County Transportation and Development. 2005. Population Growth in Clackamas County, 1990-2003. Unpublished report from Ron Skidmore, Senior Planner. Clackamas County Transportation and Development. Sunnybrook Service Center, Clackamas, Oregon.

Clevenger, A. P., Chruszcz, B. and Gunson, K. 2001. Drainage culverts as habitat linkages and factors affecting passage by mammals. Journal of Applied Ecology 38:1340-1349.

Conover, M.R., Pitt, W.C., Kessler, K.K., DuBow, T.J., and Sanborn, W.A. 1995. Review of human injuries, illnesses, and economic losses caused by wildlife in the United States. Wildlife Society Bulletin 23:407-414.

Cook, K.E. and Daggett, P. 1995. Highway roadkill, safety, and associated issues of safety and impact on highway ecotones. Task Force on Natural Resources (A1F52), Transportation Research Board, National Research Council. Unpublished report.

Cottam, D., Heath, C., Jackson, D., Mortenson, J., and Thornton, T. 2003. BlackTailed Deer Work Group Report 2002. Oregon Department of Fish and Wildlife, Portland, Oregon.

Crownover, D.R. Personal communication with TSM Unit Team Leader, Oregon Department of Transportation. Salem, Oregon. August 5, 2005.

Dasmann, R.F. and Taber, R.D. 1956. Behavior of Columbian black-tailed deer with reference to population ecology. Joumal of Mammalogy 37:143-164. 
Davis, D. Personal communication with Citizens' Representative, Citizens' Representative Office, Oregon Department of Transportation. July 29, 2005.

Dodd, N., Gagnon, J., and Schweinsburg, R. 2003. Evaluation of Measures to Minimize Wildlife-Vehicle Collisions and Maintain Wildlife Permeability Across Highways. Quarterly Progress Report 6. Arizona Game and Fish Department, Research Branch. July 5, 2003

Dusek, G.L., Wood, A.K., and Mackie, R.J. 1988. Habitat use by white-tailed deer in prairie-agricultural habitat in Montana. Prairie Naturalist 20:135-142.

Eraut, M. Personal Communication with Environmental Specialist, Federal Highways, U.S. Department of Transportation. Salem, Oregon. April 2005.

Finder, R.A., Roseberry, J. L. and Woolf, A. 1999. Site and landscape conditions at white-tailed deer/vehicle collision locations in Illinois. Landscape and Urban Planning 44:77-85.

Finder, R.A. 1998. Relationships between landscape patterns and white-tailed deer-vehicle accidents. M.S. Thesis. Southern Illinois University, Carbondale, Illinois.

Geist, V. 1981. Behavior: Adaptive strategies in mule deer. In: Wallmo, O.C. (ed.). Mule and Black-Tailed Deer of North America (pp. 157-224). University of Nebraska Press, Lincoln, Nebraska.

Grund, M.D., McAninch, J.B., and Wiggers, E.P. 2002. Seasonal movements and habitat use of female white-tailed deer associated with an urban park. Journal of Wildlife Management 66:123-130. 
Hedhund, J.H., Curtis, P.D., Curtis, G., and Williams, A.F. 2004. Methods to reduce traffic crashes involving deer: what works and what does not. Traffic Injury Prevention 5:122-131.

Heimlich, R.E. and Anderson,W.D. 2001. Development at the urban fringe and beyond, impacts on agriculture and rural land. Agricultural Economic Report \# 803. Economic Research Service, U.S. Department of Agriculture, Washington, D.C.

Hines, W.W. 1975. Black-tailed Deer Behavior and Population Dynamics in the Tillamook Burn, Oregon. Wildlife Research Report Number 5. Oregon Wildlife Commission. June 1975.

Hindelang, M., Premo, D., Rogers, E., and Premo, K Addressing deer-vehicle accidents with an ecological landscape GIS approach. Proceedings of ICOET '99: International Conference on Ecology and Transportation. Missoula, Montana. September 13-16, 1999. [Internet]. [Cited January 2, 2006\}. Available from: http://www.dot.state.fl.us/emo/sched/ICOWETpaper2.

Hubbard, M.W., Danielson, B.J., and Schmitz, R.A. 2000. Factors influencing the location of deer-vehicle accidents in Iowa. Journal of Wildlife Management 64:707-713.

Jahn, L.R. 1959. Highway mortality as an index of deer-population change. Journal of Wildlife Management 23:187-197.

Johannessen, C.L., Davenport, W.A., Millet, A., and McWilliams, S. 1971. The vegetation of the Willamette Valley. Annals of the Association of American Geographers 61:286-302. 
Kremsater, L.L. and Bunnell, F.L. 1992. Testing responses to forest edges: the example of black-tailed deer. Canadian Journal of Zoology 70:2426-2435.

Levine, N. November 2004. CrimeStat III, Version 3.0: A spatial statistics program for the analysis of crime incident locations. Ned Levine \& Associates, Houston, TX, and the National Institute of Justice, Washington, D.C [Internet]. [Cited July 15, 2005.] Available from: http://www.icpsr.umich.edu/NACJD/crimestat.html.

Marek, J. Personal communication with Traffic Engineer, Clackamas County Department of Transportation and Development, Sunnybrook Service Center. Clackamas, Oregon. November, 2005.

May, A. 1996. Urban Coyotes in Multnomah County Ecosystems. Final Report, Phase One. Study commissioned by Multnomah County Animal control Division, Department of envirommental Services. Portland, Oregon. September 30, 1996.

McCullough, D.R., Jennings, K.W., Gates, N.B., Elliott, B.G., and DiDonato, J.E. 1997. Overabundant deer populations in California. Wildlife Society Bulletin $25: 478-483$.

McCorquodale, S. 1999. Landscape and patch scale habitat use by migratory blacktailed deer in the Klickitat Basin of Washington. Northwest Science 73:1-11. Miller, F.L. 1970. Distribution patterns of black-tailed deer in relation to environment. Journal of Mammalogy 51:248-260.

Montgomery, G.G. 1963. Nocturnal movements and activity rhythms of white-tailed deer. Journal of Wildlife Management 27:422-427. 
National Oceanic and Atmospheric Administration (NOAA). Personal conversation with meteorologist intern. National Weather Forecast Office, Portland, Oregon. January 9, 2006.

Nettler, K. Personal conversation with Mount Scott homeowner. Portland, Oregon. October 2005.

Nielsen, C.K., Anderson, R.G., and Grund, M.D. 2003. Landscape influences on deer-vehicle accident areas in an urban environment. Journal of Wildlife Management 67:46-51.

Oregon Blue Book of Clackamas County [Internet]. [Cited December 14, 2005\}. Available from: http://bluebook.state.or.us/local/counties/counties03.htm. Oregon Climate Service. 2005. [Internet]. [Cited January 27, 2006]. Available from: http://www.ocs.oregonstate.edu.

Oregon Department of Fish and Wildlife. 2005. Handout on the Black-Tailed Deer. North Willamette Watershed District. Clackamas, Oregon.

Oregon Department of Transportation. 1996-2004. Deer-vehicle crashes in Clackamas, Washington, and Multnomah Counties, January 1, 1996-December 31, 2004. Crash Analysis and Reporting Unit, Transportation Data Section, Transportation Development Division. Supplied February 14, 2005 by Sylvia M. Vogel, Crash Reporting Technician Leader, and July 11, 2005 by Kelly R. Hawley, Crash Analyst. 
Oregon Department of Transportation. 2004. Driver population and vehicle registration. Unpublished report from Renee Davis, DMV Driver Programs. Supplied November 27, 2005.

Oregon Department of Transportation. 2005. Oregon vehicle miles traveled by county. Trans Dev - Transportation Data [internet]. [cited December 14, 2005]. Available from: http://www.oregon.gov/ODOT/TD/TDATA/tsm/vmtpage.shtml.

Oregon Mileage Reports. 1998-2004. Summary of Mileages. Public Road Inventory [Internet]. [Cited December 14, 2005]. Available from: http://www.oregon.gov/ODOT/TD/TDATA/rics/PublicRoadsInventory.shtml\# OREGON_MILEAGE_REPORT.

Ormsby, T., Napoleon, E., Burke, R., Groessl, C., and Feaster, L. 2004. Getting to Know ArcGIS Desktop. Updated for ArcGIS 9. ESRI Press, Redlands, California.

Peek, F.W. and Bellis, E.D. 1969. Deer movements and behavior along an interstate highway. Highway Research News 36:36-42.

Pojar, T.M. 1975. Effectiveness of a lighted, animated deer crossing sign. Journal of Wildlife Management 39:87-91.

Population Research Center. 2004. Oregon Population Report. College of Urban and Public Affairs, Portland State University, Portland, Oregon.

Portland Oregon Regional Transportation Archive Listing (PORTAL). I-205 north and southbound congested periods, October 2005[Internet]. [Cited November 20, 2005]. Available from: http://portal.its.pdx.edu. 
Porter, W. F., Mathews, N. E., Underwood, H. B., Sage Jr., R. W., and Behrend, D. F. 1991. Social organization in deer: implications for localized management. Environmental Management 15:809-814.

Price, J.O. Personal communication with GIS technician. Metro Data Resource Center, Metro Regional Government. Portland, Oregon. 2002.

Progulske, D.R. and Duerre, D.C. 1964. Factors influencing spotlighting counts of deer. Journal of Wildlife Management 29:27-34.

Puglisi, M.J., Lindzey, J.S., and Bellis, E.D. 1974. Factors associated with highway mortality of white-tailed deer. Jounal of Wildlife Management 38:799-807.

Region Land Information Survey (RLIS Lite). Shapefiles, ArcSDE Layers, Coverages, Grids, Photos, and Metadata. Data Resource Center. Metro Regional Government. Portland, Oregon. [Internet]. [Cited January 1, 2006\}. Available from http://geode.metro-region.org/metadata/nav.cfm.

Reilly, R.E. and Green, H.E. 1974. Deer mortality on a Michigan interstate highway. Journal of Wildlife Management 38:16-19.

Riitters, K. H. and Wickham, J. D. 2003. How far to the nearest road? Frontiers in Ecology and the Environment 1:125-129.

Robinson, R.M., Thomas, J.W., and Marburger, R.G. 1965. The reproductive cycle of male white-tailed deer in central Texas. Journal of Wildlife Management 29:53-58.

Romin, L.A. and Bissonette, J.A. 1996a. Temporal and spatial distribution of highway mortality of mule deer on newly constructed roads at Jordanelle Reservoir, Utah. The Great Basin Naturalist 56:1-11. 
Romin, L.A. and Bissonette, J.A. 1996b. Deer-vehicle collisions: status of state monitoring activities and mitigation efforts. Wildlife Society Bulletin 24:276283.

Roseberry, J.L. and Woolf, A. 1998. Habitat-population density relationships for white-tailed deer in Illinois. Wildlife Society Bulletin 26:252-258.

Rue, L.L. III. 1989. The Deer of North America. Outdoor Life Books, Danbury, CT. Skidmore, R. Personal Communication with Transportation Planner, Clackamas County Department of Transportation and Development, Sunnybrook Service Center. Clackamas, Oregon. November 2002-2005.

Slater, F.M. 2002. An assessment of wildlife road casualties - the potential discrepancy between numbers counted and numbers killed. Web Ecology $3: 33-42$

Traffic Counter Studies for Roads Maintained by Clackamas County. 1997, 2002, 2005. Traffic Engineering Section, Clackamas County Transportation and Development, Sunnybrook Service Center, Clackamas, Oregon.

Turner, M.G., Gardner, R.H., and O'Neill, R.V. 2003. Landscape Ecology in Theory and Practice: Pattern and Process. Springer-Verlag, New York.

U.S. Census Bureau. Annual new privately-own residential building permits for Clackamas County. 2000-2004 building permits [internet]. [Cited December 14, 2005]. Available from: http://censtats.census.gov/cgi-in/bldgprmt/bldgbrowse.pl. 
U.S. Naval Observatory (USNO). 1996. Nautical Twilight (begin and end)

[Internet]. Astronomical Applications Department, Washington, D.C. [Cited July 1, 2005]. Available from: http://aa.usno.navy.mil/data/docs/RS_OneYear.html

VanDruff, L.W., Bolen, E.G., and San Julian, G. 1994. Management of urban wildlife. In: Bookhout, T. A. (Ed.), Research and ManagementTechniques for Wildlife and Habitats. The Wildlife Society, Bethesda, Maryland.

Verts, B.J. and Carraway, L.N. 1998. Land Mammals of Oregon. University of California Press, Berkeley.

Wallmo, O.C. 1981. Mule and black-tailed deer distribution and habitats. In: Wallmo, O.C. (ed.). Mule and Black-Tailed Deer of North America (pp. 1-26). University of Nebraska Press, Lincoln, Nebraska.

Weinman, R. 2005. Personal Communication with PrincipleTransportation Planner, Clackamas County Department of Transportation and Development, Sunnybrook Service Center. Clackamas, Oregon. November 8, 2005.

Western Transportation Institute. Roadkill Data Collection System [Internet]. [Cited December 31, 2005]. Available from: www.coe.montana.edu/wti. Montana State University, Bozeman. 
APPENDICES 
APPENDIX A

POPULATION GROWTH IN CLACKAMAS COUNTY, 1990-2003 
Table A.1. Population growth in Clackamas County, 1990-2003. Source: Ron Skidmore, Senior Planner, Clackamas County Transportation and Development.

\begin{tabular}{|c|c|c|c|c|c|c|}
\hline & \begin{tabular}{|c|} 
July 1 \\
Population \\
Estimates
\end{tabular} & $\begin{array}{l}\text { April } 1 \\
\text { Census } \\
\text { Count }\end{array}$ & & & Growth & $\begin{array}{l}\text { Growth } \\
\text { Percent } \\
\text { Change }\end{array}$ \\
\hline & 2003 & 1990 & & & $\begin{array}{l}1990- \\
2003\end{array}$ & $\begin{array}{l}1990- \\
2003\end{array}$ \\
\hline CLACKAMAS & 353,450 & 278,850 & & & 74,600 & $26.8 \%$ \\
\hline Barlow & 140 & 118 & & & 22 & $18.6 \%$ \\
\hline Canby & 13,910 & 8,990 & & & 4,920 & $54.7 \%$ \\
\hline Estacada & 2,440 & 2,016 & & & 424 & $21.0 \%$ \\
\hline Gladstone & 11,790 & 10,152 & & & 1,638 & $16.1 \%$ \\
\hline Happy Valley & 6,370 & 1,519 & & & 4,851 & $319.4 \%$ \\
\hline \begin{tabular}{|l|} 
Johnson City \\
\end{tabular} & 630 & 586 & & & 44 & $7.5 \%$ \\
\hline Lake Oswego* & 33,530 & 28,317 & 35,750 & 30,576 & 5,213 & $18.4 \%$ \\
\hline Milwaukie & 20,580 & 18,670 & & & 1,910 & $10.2 \%$ \\
\hline Molalla & 5,800 & 3,637 & - & & 2,163 & $59.5 \%$ \\
\hline Oregon City & 28,100 & 14,698 & & & 13,402 & $91.2 \%$ \\
\hline Rivergrove* & 290 & 267 & 320 & 294 & 23 & $8.6 \%$ \\
\hline Sandy & 6,200 & 4,154 & & & 2,046 & $49.3 \%$ \\
\hline West Linn & 23,820 & 16,389 & & & 7,431 & $45.3 \%$ \\
\hline Wilsonville* & 14,225 & 7,096 & 15,590 & 7,106 & 7,129 & $100.5 \%$ \\
\hline Portland & 770 & 707 & & & 63 & $8.9 \%$ \\
\hline Tualatin & 2,820 & 1,406 & & & 1,414 & $100.6 \%$ \\
\hline Uninc. & 182,035 & 160,128 & & & 21,907 & $13.7 \%$ \\
\hline Total & 353,450 & 278,850 & & & 74,600 & $26.8 \%$ \\
\hline \multicolumn{7}{|c|}{ County Unincorp in Metro UGB: 99,118} \\
\hline \multicolumn{7}{|c|}{ County Incorporated in Metro UGB: 142,925} \\
\hline \multicolumn{7}{|c|}{ County Population in Metro UGB: 242,043} \\
\hline \multicolumn{7}{|c|}{ Total County Incorporated: 171,415} \\
\hline
\end{tabular}


APPENDIX B

CALCULATING

DUSK AND DAWN 
Table B.1. Time (24-hour clock) of beginning and ending of nautical twilight, sunrise, and sunset times for the first day of each month of the year 1996, with dawn and dusk periods used in this study. Dawn is earliest nautical twilight to latest sunrise for month. Dusk is earliest sunset to latest nautical twilight for month. Source: U.S. Naval Observatory 1996.

$\begin{array}{llllllr}\text { Month } & \begin{array}{l}\text { A.M. } \\ \text { Nautical } \\ \text { Twilight }\end{array} & \begin{array}{l}\text { P.M. } \\ \text { Nautical } \\ \text { Twilight }\end{array} & \text { Sunrise } & \text { Sunset } & \text { Dawn } & \text { Dusk } \\ & & 1749 & 0751 & 1637 & 0626-0751 & 1637-1822 \\ \text { January } & 0639 & 1824 & 0732 & 1717 & 0546-0732 & 1717-1901 \\ \text { February } & 0625 & 1902 & 0648 & 1758 & 0446-0648 & 1758-1944 \\ \text { March } & 0544 & 1945 & 0550 & 1839 & 0346-0550 & 1839-2030 \\ \text { April } & 0444 & 2032 & 0458 & 1918 & 0300-0458 & 1918-2117 \\ \text { May } & 0344 & 2118 & 0425 & 1953 & 0257-0425 & 1953-2131 \\ \text { June } & 0259 & 2131 & 9426 & 2003 & 0258-0454 & 1939-2131 \\ \text { July } & 0258 & 2055 & 0455 & 1938 & 0338-0531 & 1849-2055 \\ \text { August } & 0338 & 1955 & 0532 & 1847 & 0425-0608 & 1752-1955 \\ \text { September } & 0425 & 1854 & 0609 & 1750 & 0505-0649 & 1658-1854 \\ \text { October } & 0505 & 1803 & 0651 & 1657 & 0545-0730 & 1629-1803 \\ \text { November } & 0545 & 1739 & 0731 & 1629 & 0620-0751 & 1629-1749\end{array}$


Table B.2. Dawn, dusk, dusk +2 hours, morning and evening rush hours rounded to hour increments. Hours with $\leq 5$ minutes are dropped. e.g., 1007 becomes 0959 becomes 0900. Rush hours correspond to Pacific Standard Time.

$\begin{array}{lllcll}\text { Month } & \text { Dawn } & \text { Dusk } & \begin{array}{c}\text { Dusk } \\ +2 \text { Hours }\end{array} & \begin{array}{l}\text { Morning } \\ \text { Rush Hour }\end{array} & \begin{array}{l}\text { Evening } \\ \text { Rush Hour }\end{array} \\ \text { January } & 0600-0700 & 1600-1800 & 1600-2000 & 0600-0900 & 1600-1900 \\ \text { February } & 0500-0700 & 1700-1800 & 1700-2000 & 0600-0900 & 1600-1900 \\ \text { March } & 0400-0600 & 1800-1900 & 1800-2100 & 0600-0900 & 1600-1900 \\ \text { April } & 0300-0500 & 1800-2000 & 1800-2200 & 0500-0800 & 1500-1800 \\ \text { May } & 0300-0400 & 1900-2100 & 1900-2300 & 0500-0800 & 1500-1800 \\ \text { June } & 0300-0400 & 1900-2100 & 1900-2300 & 0500-0800 & 1500-1800 \\ \text { July } & 0300-0400 & 1900-2100 & 1900-2300 & 0500-0800 & 1500-1800 \\ \text { August } & 0300-0500 & 1800-2000 & 1800-2200 & 0500-0800 & 1500-1800 \\ \text { September } & 0400-0500 & 1700-1900 & 1700-2100 & 0500-0800 & 1500-1800 \\ \text { October } & 0500-0600 & 1700-1800 & 1700-2000 & 0500-0800 & 1500-1800 \\ \text { November } & 0500-0700 & 1600-1700 & 1600-1900 & 0600-0900 & 1600-1900 \\ \text { December } & 0600-0700 & 1600-1700 & 1600-1900 & 0600-0900 & 1600-1900\end{array}$


APPENDIX C

CONGESTION FREQUENCY ON I-205 

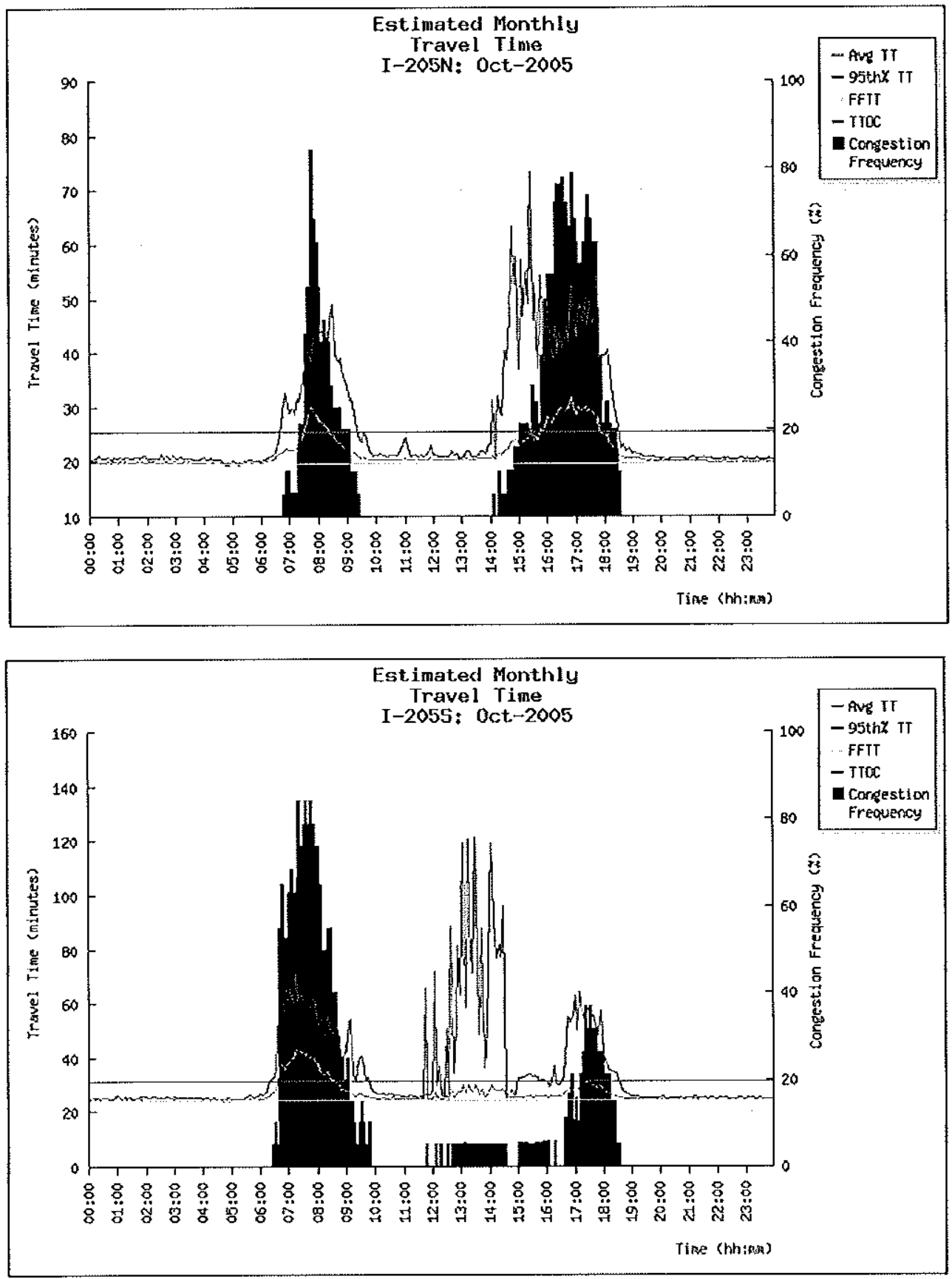

Figure C.1. Congestion frequency on I-205 for October 2005. Source: Portland Oregon Regional Transportation Archive List 2005. 
Table D.1. Frequency of other DVA within $0.5 \mathrm{mi}$ search radius of each DVA.

Source: Fuzzy mode routine/Clackamas County carcass pickup reports, 1997-2004.

\begin{tabular}{|c|c|c|c|}
\hline $\begin{array}{l}\text { \# of DVA/ } \\
0.5 \mathrm{mi} \text { search radius }\end{array}$ & $\begin{array}{l}\text { \# of DVA } \\
\text { Locations }\end{array}$ & $\begin{array}{l}\text { Break } \\
\text { Point }\end{array}$ & $\begin{array}{c}\text { Percentage } \\
\text { of Total } \\
\text { DVA }\end{array}$ \\
\hline 1 & 149 & & \\
\hline 2 & 139 & & \\
\hline 3 & 146 & & \\
\hline 4 & 134 & & \\
\hline 5 & 147 & & \\
\hline 6 & 116 & & \\
\hline 7 & 111 & 942 & $63 \%$ \\
\hline 8 & 57 & & \\
\hline 9 & 63 & & \\
\hline 10 & 53 & & \\
\hline 11 & 59 & & \\
\hline 12 & 58 & & \\
\hline 13 & 52 & & \\
\hline 14 & 51 & & \\
\hline 15 & 36 & 429 & $29 \%$ \\
\hline 16 & 20 & & \\
\hline 17 & 6 & & \\
\hline 18 & 18 & & \\
\hline 19 & 6 & & \\
\hline 20 & 16 & & \\
\hline 21 & 22 & & \\
\hline 22 & 8 & & \\
\hline 23 & 6 & & \\
\hline 24 & 12 & & \\
\hline 25 & 9 & & \\
\hline 26 & 3 & & \\
\hline 27 & 3 & 129 & $9 \%$ \\
\hline
\end{tabular}


APPENDIX E

\section{CRIMESTAT III}

NEAREST NEIGHBOR CLUSTERING ROUTINE RESULTS 
Table E.1. Identification of 41 DVA Hotspots in Clackamas County, Source: Nearest neighbor clustering at $0.5 \mathrm{mi}$ search radius With minimum cluster size of 10 DVA.

Nearest Neighbor Hierarchical Clustering:

Sample size.............. 1853

Likelihood of grouping

pair of points by chance...: 0.50000 (50.000응)

Z-value for confidence

interval.............. 0.000

Measurement type.......... Direct

Output units..................... Square Miles, Points per Square Miles

Standard Deviations ....... 1.0

Clusters found........... 41

Simulation runs............ 0

Displaying 41 ellipse(s) starting from 1

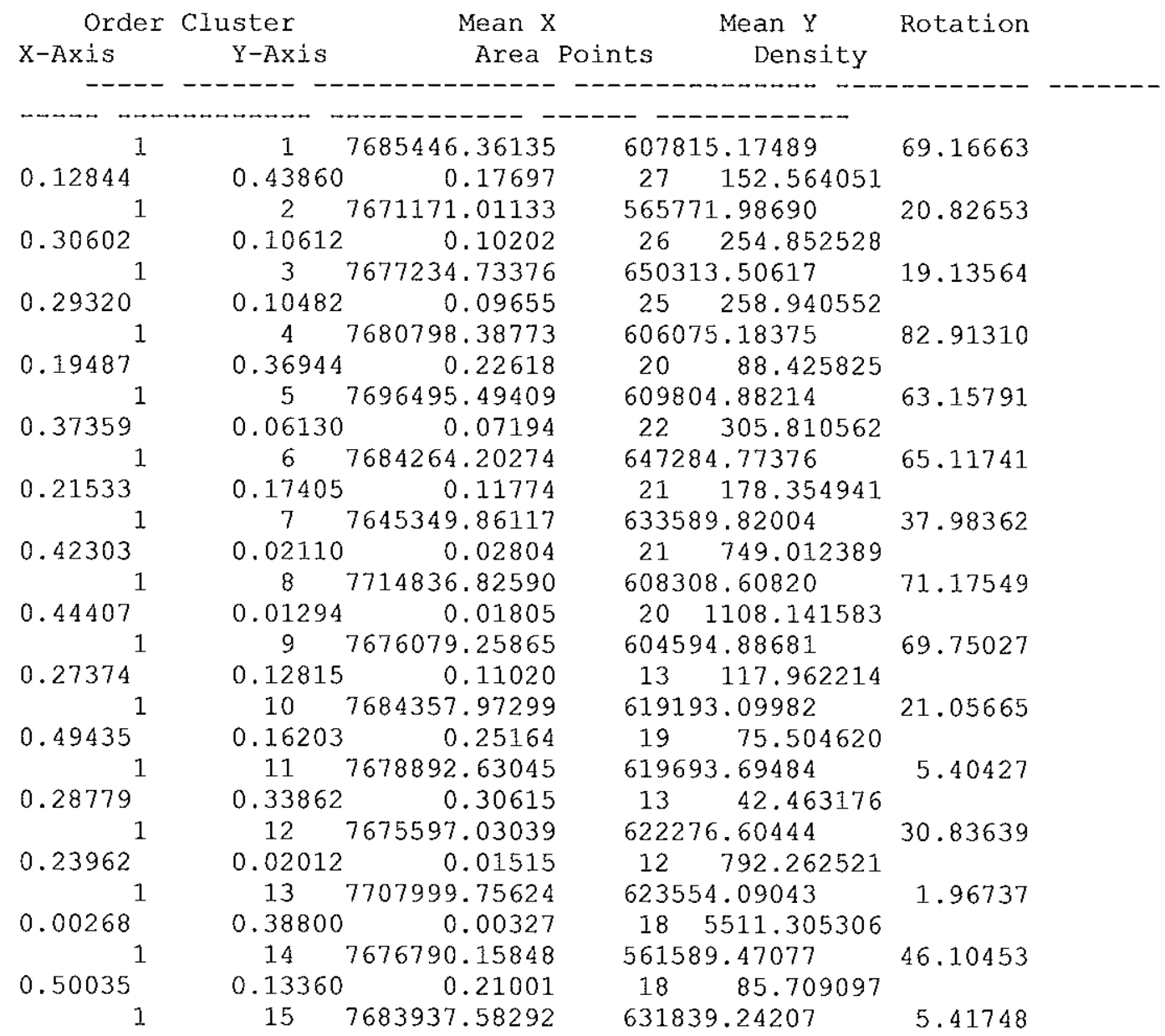




\begin{tabular}{|c|c|c|c|c|}
\hline 0.09835 & 0.43769 & 0.13524 & 118.307966 & \\
\hline 1 & 16 & 7650071.69504 & 609149.11277 & 50.63074 \\
\hline 0.02020 & 0.41442 & 0.02629 & 608.518479 & \\
\hline 1 & 17 & 7673827.83074 & 646792.29082 & 43.96855 \\
\hline 0.39789 & 0.09845 & $5 \quad 0.12306$ & $16 \quad 130.017651$ & \\
\hline 1 & 18 & 7675278.77089 & 587008.73655 & 12.69421 \\
\hline 0.39208 & 0.10930 & 0.13463 & 118.840122 & \\
\hline 1 & 19 & 7683018.26878 & 589031.58231 & 59.24070 \\
\hline 0.41542 & 0.15596 & 0.20355 & 78.606609 & \\
\hline 1 & 20 & 7630673.36934 & 609826.77528 & 2.63683 \\
\hline 0.40925 & 0.14051 & $1 \quad 0.18065$ & $15 \quad 83.033444$ & \\
\hline 1 & 21 & 7698558.50137 & 588036.58460 & 4.78805 \\
\hline 0.48195 & 0.13373 & 0.20248 & 74.082139 & \\
\hline 1 & 22 & 7638707.77543 & 634845.37979 & 15.56284 \\
\hline 0.17243 & 0.35911 & 0.19454 & 77.105723 & \\
\hline 1 & 23 & 7664659.96892 & 600008.87774 & 56.56689 \\
\hline 0.19063 & 0.41329 & 0.24751 & 60.602509 & \\
\hline 1 & 24 & 7626225.34501 & 618135.20954 & 25.16753 \\
\hline 0.05446 & 0.45512 & $2 \quad 0.07787$ & $15 \quad 192.636379$ & \\
\hline 1 & 25 & 7719209.37804 & 597567.88091 & 59.42370 \\
\hline 0.51823 & 0.00384 & 0.00625 & $15 \quad 2401.807141$ & \\
\hline 1 & 26 & 7689466.48337 & 627584.44837 & 76.66908 \\
\hline 0.28839 & 0.02765 & 0.02505 & 558.826540 & \\
\hline 1 & 27 & 7736831.92002 & 616260.20392 & 84.15516 \\
\hline 0.15052 & 0.36871 & $1 \quad 0.17435$ & $14 \quad 80.296219$ & \\
\hline 1 & 28 & 7678457.99940 & 543533.42469 & 80.33610 \\
\hline 0.23352 & 0.39774 & 0.29179 & 47.979932 & \\
\hline 1 & 29 & 7691939.69832 & 561171.43694 & 48.37379 \\
\hline 0.05821 & 0.43265 & 0.07912 & 164.301838 & \\
\hline 1 & 30 & 7652234.11813 & 580121.71182 & 37.07629 \\
\hline 0.35736 & 0.07351 & $1 \quad 0.08252$ & $13 \quad 157.532790$ & \\
\hline 1 & 31 & 7647139.05029 & 603160.16199 & 3.41388 \\
\hline 0.1 & 0.42652 & $2 \quad 0.21427$ & $13 \quad 60.670328$ & \\
\hline 1 & 32 & 7719249.15433 & 575033.06208 & 86.14881 \\
\hline 0.41953 & 0.04256 & 0.05610 & 231.737623 & \\
\hline 1 & 33 & 7703285.27344 & 548552.25406 & 17.65252 \\
\hline 0.41762 & 0.16187 & 0.21237 & 61.213673 & \\
\hline 1 & 34 & 7608558.08235 & 597251.42374 & 52.85022 \\
\hline 0.03048 & 0.22147 & 0.02121 & $12 \quad 565.902$ & \\
\hline 1 & 35 & 7705814.11008 & 630294.36974 & 6.60754 \\
\hline 0.51153 & 0.08901 & 0.14304 & $12 \quad 83.893669$ & \\
\hline 1 & 36 & 7672660.83650 & 609937.46997 & 46.55628 \\
\hline 0.38980 & 0.18947 & 0.23202 & 51.718784 & \\
\hline 1 & 37 & 7710287.09739 & 600854.65765 & 25.00722 \\
\hline 0.28628 & 0.07979 & 0.07176 & 153.279801 & \\
\hline 1 & 38 & 7665048.43835 & 540766.57985 & 61.29454 \\
\hline 0.39078 & 0.17858 & 0.21923 & 50.174741 & \\
\hline 1 & 39 & 7641795.07318 & 611764.55173 & 81.82928 \\
\hline 0.34055 & 0.06284 & 0.06723 & $11 \quad 163.624814$ & \\
\hline 1 & 40 & 7634108.54223 & 622686.94544 & 64.63413 \\
\hline 0.57855 & 0.14409 & 0.26189 & 42.002093 & \\
\hline 1 & 41 & 7670578.35786 & 523900.56218 & 82.3 \\
\hline .40749 & 0.06273 & 0.08030 & 136.987187 & \\
\hline
\end{tabular}




\section{APPENDIX F}

\section{CLACKAMAS COUNTY HOTSPOTS}

LANDSCAPE CHARACTERISTICS AND LOCATIONS 


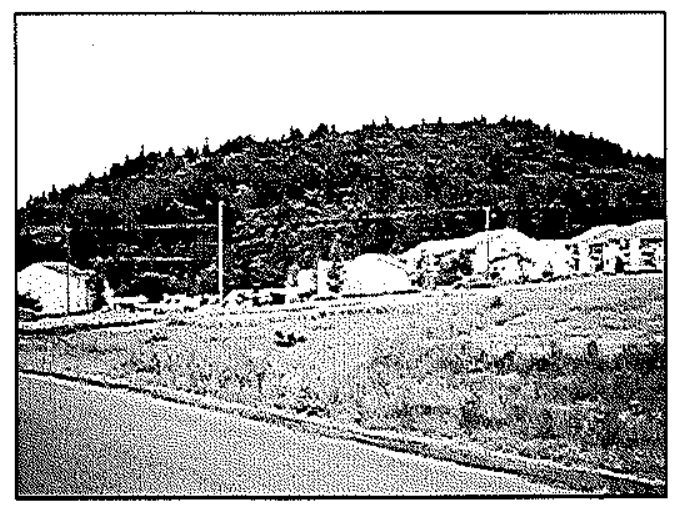

4.

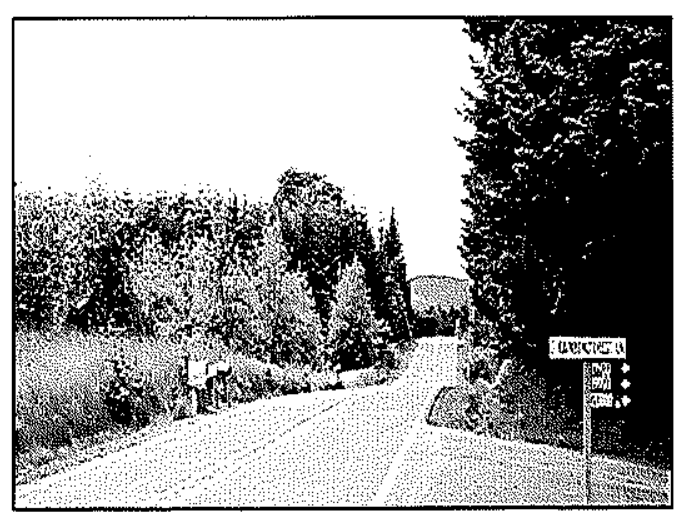

2.

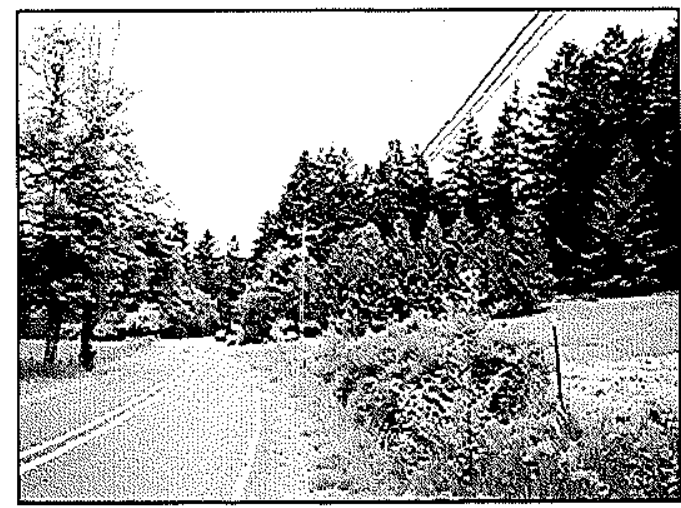

5.

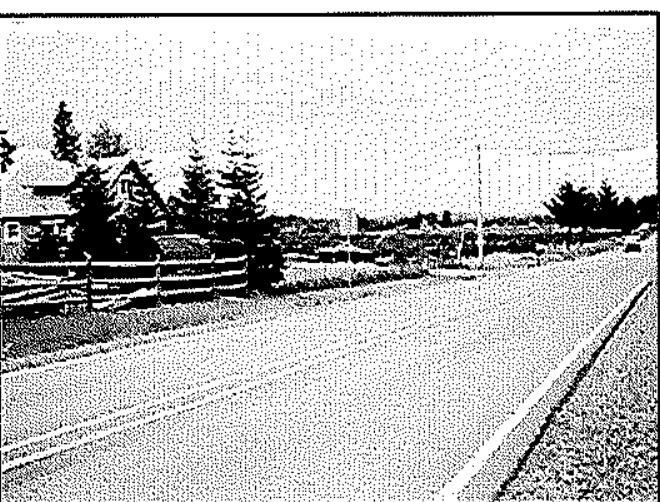

3.

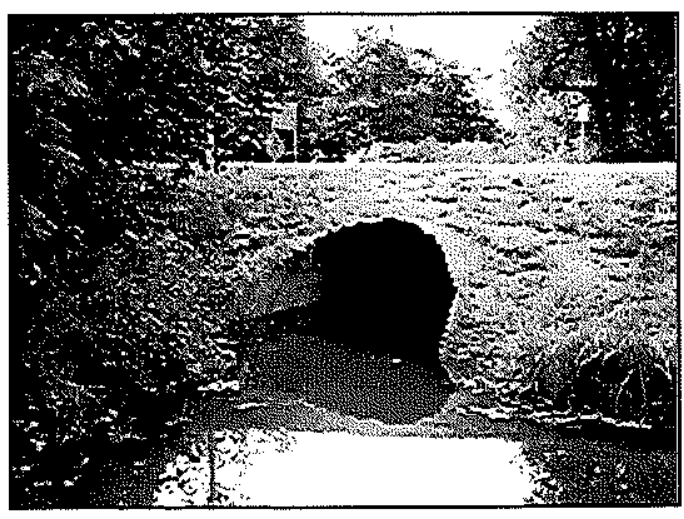

6.

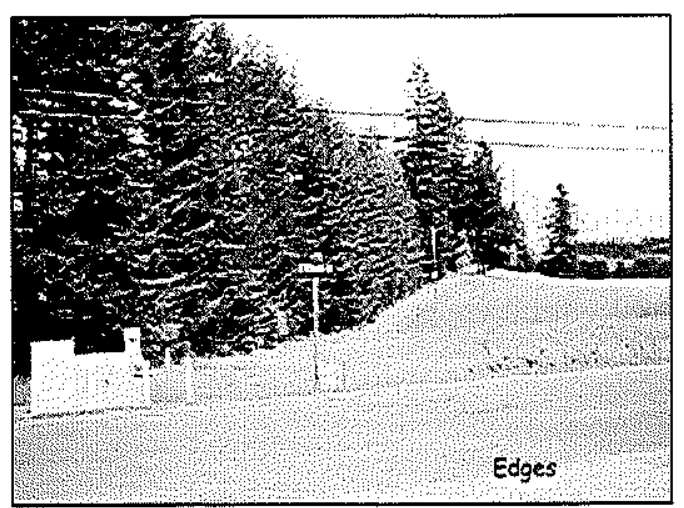

Figure F.1. Six DVA model factors. 1) road proximity to large forested areas, 2) road intersects wooded area,

3) road intersects water feature 4) road separates forest (cover) and field (food), 5) scattered residences,

6) area is mix of forest and field with edges. 
1.

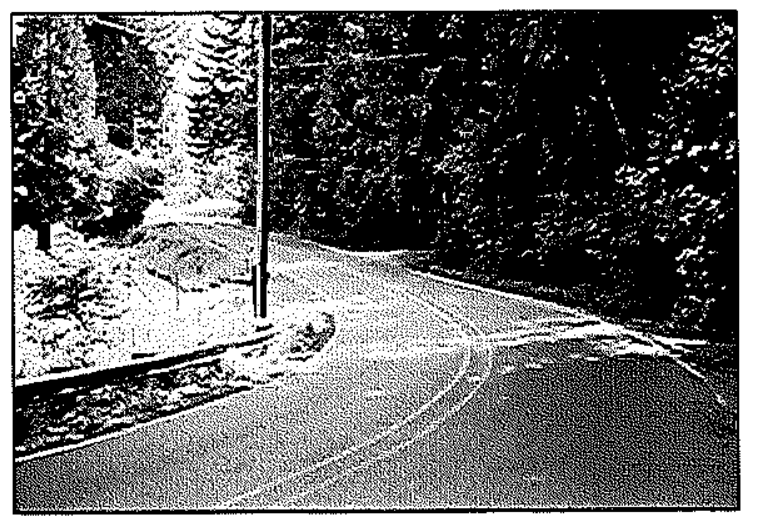

2.

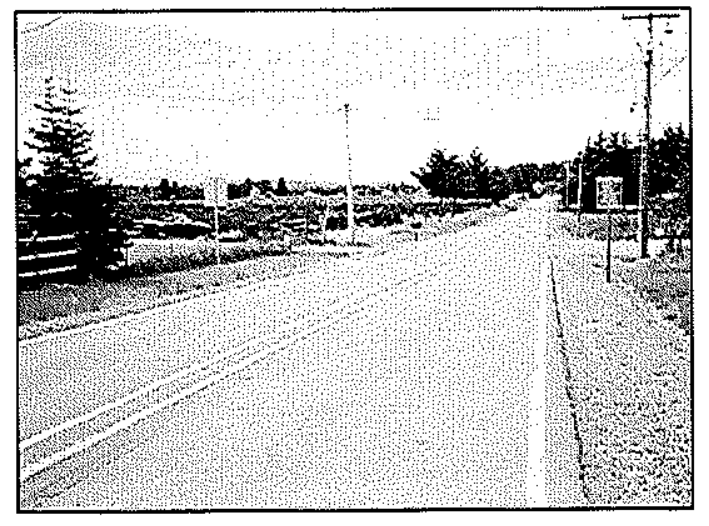

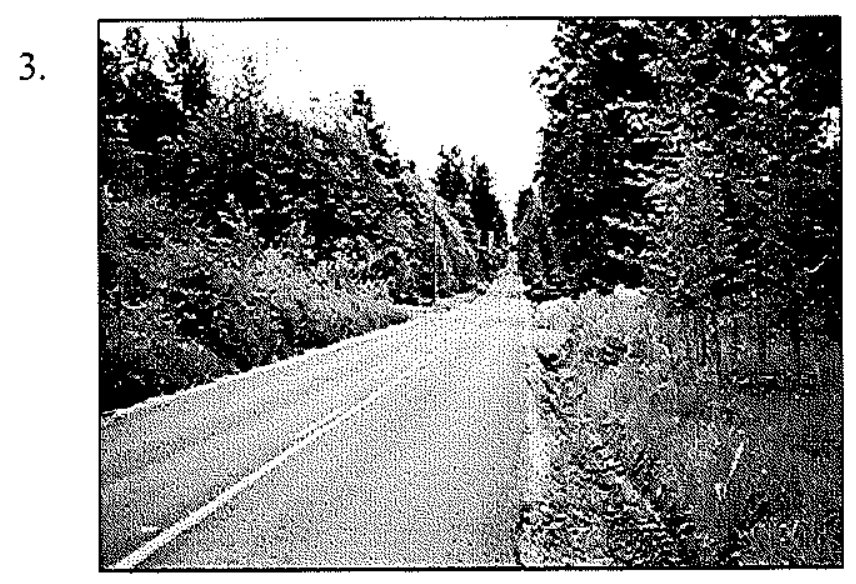

Figure F.2. DVA model visibility factors. 1) short in-line visibility, high road sinuosity, 2) long in-line visibility, high vehicle speeds, 3 ) dense vegetation adjacent to road hides approaching deer. 


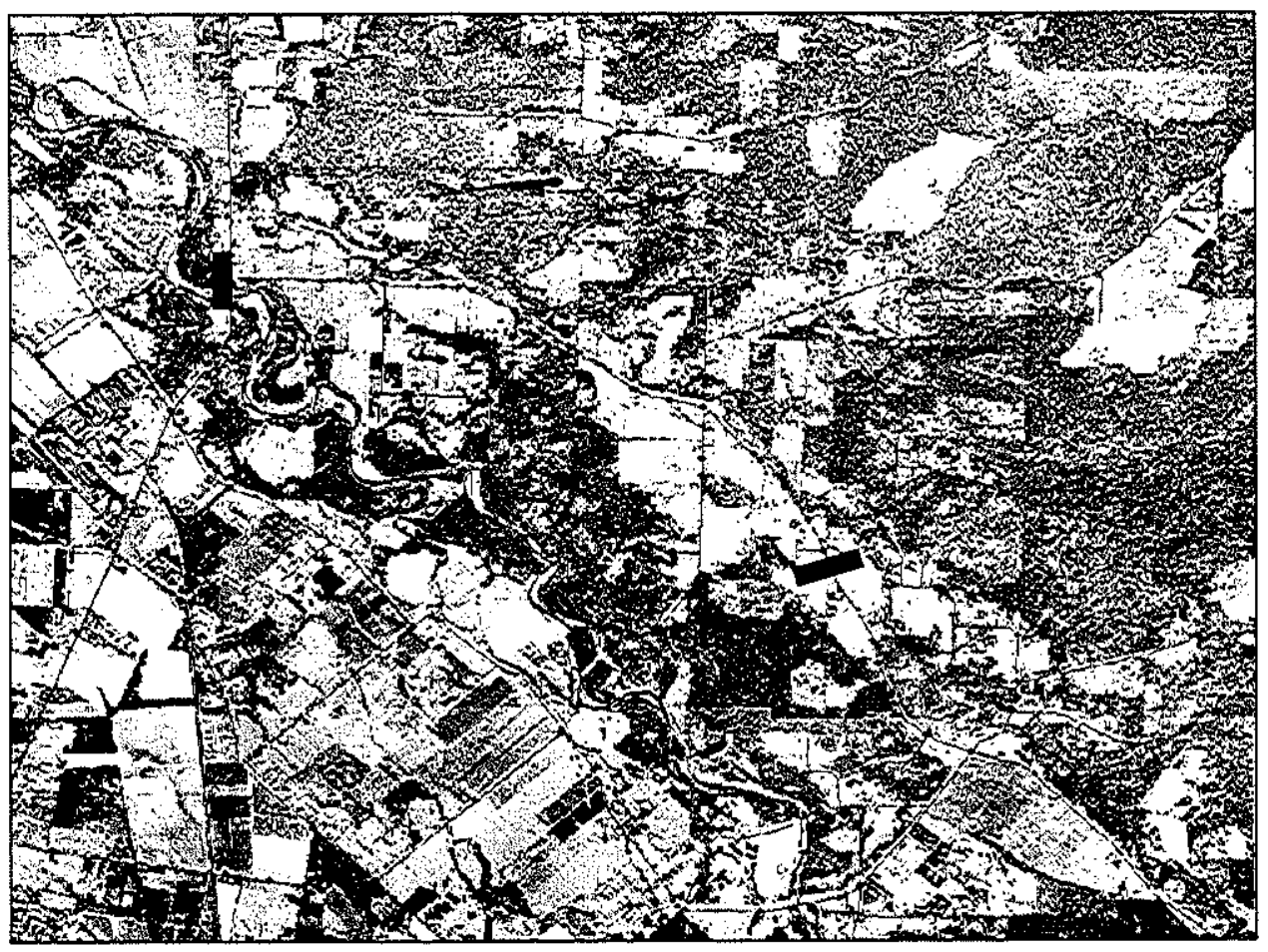

Figure F.3.

UNION MILLS ROAD HOTSPOT LOCATION

(between black bars)

Hotspot Identification \#2

Black dots represent one or more DVA

See: Tables F.1 and F.2 for location and details 
Table F.1. The presence of white-tailed and mule deer DVA model factors in the 19 largest DVA hotspots in Clackamas County. Site identification and site DVA in parentheses in Table F.2. Source: Clackamas County Transportation and Development 10' orthophotography for 1998 .

\begin{tabular}{|c|c|c|c|c|c|c|c|c|c|c|c|c|c|c|c|c|c|c|c|c|}
\hline \multirow[b]{2}{*}{ Model Factor } & \multirow{2}{*}{\begin{tabular}{|c|}
$\%$ \\
Total \\
\end{tabular}} & \multicolumn{19}{|c|}{ Hotspot Identification Number } \\
\hline & & 1 & 2 & 3 & 4 & 5 & 6 & 7 & 8 & 9 & 10 & 11 & 12 & 13 & 14 & 15 & 16 & 17 & 18 & 19 \\
\hline & & & & & & & & & & & & & & & & & & & & \\
\hline \multicolumn{21}{|l|}{ Land Use } \\
\hline scattered residences & 100 & $\mathrm{x}$ & $x$ & $\mathrm{x}$ & $\mathrm{x}$ & $\mathrm{x}$ & $\mathrm{x}$ & $\mathrm{x}$ & $\mathrm{x}$ & $\mathrm{x}$ & $\mathrm{x}$ & $\mathrm{x}$ & $x$ & $\mathrm{x}$ & $\mathrm{x}$ & $\mathrm{x}$ & $\mathrm{x}$ & $\mathrm{x}$ & $\mathrm{x}$ & $\mathrm{x}$ \\
\hline man-made corridors directing deer to road & 89 & $\mathrm{x}$ & $\mathrm{x}$ & $\mathrm{x}$ & $\mathrm{x}$ & $x$ & $\mathrm{x}$ & $\mathrm{x}$ & $\mathrm{x}$ & & $\mathrm{x}$ & $x$ & $x$ & $\mathrm{x}$ & $\mathrm{x}$ & & $\mathrm{x}$ & $\mathrm{x}$ & $\mathrm{x}$ & $\mathrm{x}$ \\
\hline \multirow{2}{*}{\multicolumn{21}{|c|}{ Landscape }} \\
\hline & & & & & & & & & & & & & & & & & & & & \\
\hline road intersects or parallels riparian corridors/wetlands & 89 & $\mathbf{x}$ & $\mathrm{x}$ & $\mathrm{x}$ & $\mathrm{x}$ & $\mathrm{x}$ & $\mathrm{x}$ & $\mathrm{x}$ & $\mathrm{x}$ & $\mathrm{x}$ & $\mathrm{x}$ & $x$ & $\mathrm{x}$ & $\mathrm{x}$ & $\mathrm{x}$ & & $\mathrm{x}$ & $\mathrm{x}$ & & $\mathrm{x}$ \\
\hline road adjacent to or intersects large wooded areas & 100 & $\mathrm{x}$ & $\mathrm{x}$ & $\mathrm{x}$ & $\mathrm{x}$ & $\mathrm{x}$ & $\mathrm{x}$ & $\mathrm{x}$ & $\mathrm{x}$ & $\mathrm{x}$ & $\mathrm{x}$ & $\mathrm{x}$ & $\mathrm{x}$ & $\mathrm{x}$ & $x$ & $\mathrm{x}$ & $\mathrm{x}$ & $\mathrm{x}$ & $\mathrm{x}$ & $\mathrm{x}$ \\
\hline area is mix of forest and fields & 100 & $\mathrm{x}$ & $\mathrm{x}$ & $\mathrm{x}$ & $\mathrm{x}$ & $\mathrm{x}$ & $\mathrm{x}$ & $\mathrm{x}$ & $\mathrm{x}$ & $\mathrm{x}$ & $\mathrm{x}$ & $\mathrm{x}$ & $\mathrm{x}$ & $\mathrm{x}$ & $\mathrm{x}$ & $\mathrm{x}$ & $\mathrm{x}$ & $\mathrm{x}$ & $\mathrm{x}$ & $\mathrm{x}$ \\
\hline road separates forest and field & 95 & $\mathrm{x}$ & $\mathrm{x}$ & & $\mathrm{x}$ & $\mathrm{x}$ & $\mathrm{x}$ & $\mathrm{x}$ & $\mathrm{x}$ & $\mathrm{x}$ & $\mathrm{x}$ & $\mathrm{x}$ & $x$ & $\mathrm{x}$ & $\mathrm{x}$ & $\mathrm{x}$ & $\mathrm{x}$ & $\mathrm{x}$ & $\mathrm{x}$ & $\mathrm{x}$ \\
\hline \multicolumn{21}{|l|}{ Visibility } \\
\hline road has long in-line visibility & 95 & $\mathrm{x}$ & $\mathrm{x}$ & $\mathrm{x}$ & $\mathrm{x}$ & $\mathrm{x}$ & $\mathrm{x}$ & $x$ & $\mathrm{x}$ & $\mathrm{x}$ & $\mathrm{x}$ & $x$ & & $x$ & $x$ & $\mathrm{x}$ & $\mathrm{x}$ & $x$ & $\mathrm{x}$ & $\mathrm{x}$ \\
\hline road has short in-line visibility (sinuosity) & 5 & $\mathrm{x}$ & & & & & & & & & & & & & & & & & & \\
\hline dense vegetation approaches road on one or both sides & 89 & $x$ & $\mathrm{x}$ & & \begin{tabular}{|l|}
$x$ \\
\end{tabular} & $\mathrm{x}$ & $x$ & $\mathrm{x}$ & $\mathrm{x}$ & $x$ & $\mathrm{x}$ & & $\mathrm{x}$ & $\mathrm{x}$ & $\mathrm{x}$ & $x$ & $\mathrm{x}$ & $\mathrm{x}$ & $\mathrm{x}$ & $\mathrm{x}$ \\
\hline & & & & & & & & & & & & & & & & & & & & \\
\hline
\end{tabular}


Table F.2. The nineteen largest DVA hotspots by hotspot identification number, with location, length, number of DVA, and DVA density. $\mathrm{SR}=$ search radius.

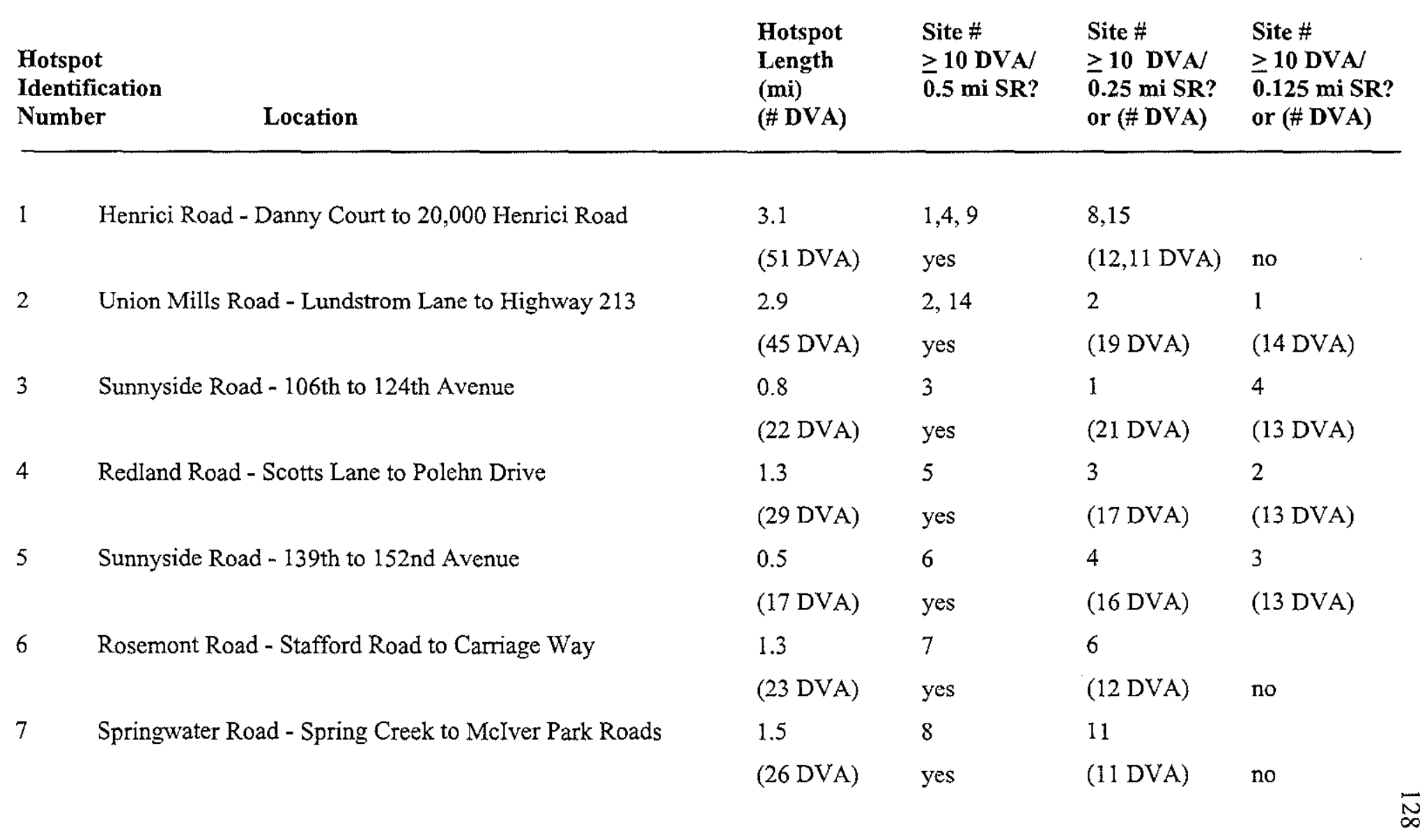




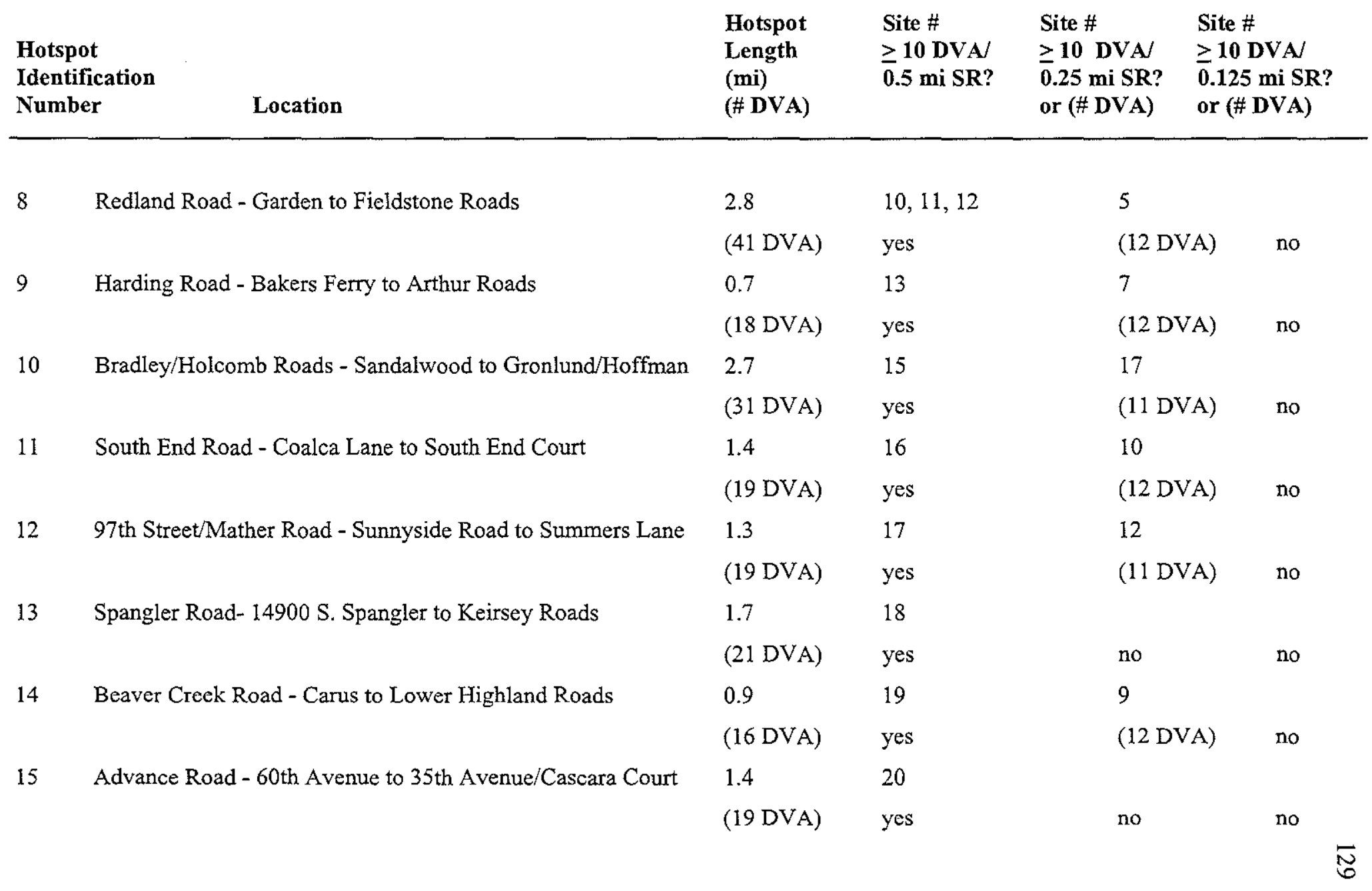




\begin{tabular}{|c|c|c|c|c|c|}
\hline \multicolumn{2}{|c|}{$\begin{array}{l}\text { Hotspot } \\
\text { Identification } \\
\text { Number }\end{array}$} & \multirow{2}{*}{$\begin{array}{l}\begin{array}{l}\text { Hotspot } \\
\text { Length } \\
\text { (mi) } \\
\text { (\# DVA) }\end{array} \\
1.4\end{array}$} & \multirow{2}{*}{$\begin{array}{l}\text { Site \# } \\
\geq 10 \text { DVAV } \\
0.5 \text { mi SR? } \\
22\end{array}$} & \multirow[t]{2}{*}{$\begin{array}{l}\text { Site \# } \\
\geq 10 \mathrm{DVA} / \\
0.25 \mathrm{mi} \mathrm{SR} \text { ? } \\
\text { or (\# DVA) }\end{array}$} & $\begin{array}{l}\text { Site \# } \\
\geq 10 \text { DVA } \\
0.125 \text { mi SR? } \\
\text { or (\# DVA) }\end{array}$ \\
\hline 16 & Stafford Road - Rosemont to Johnson Roads/Ashdown Circle & & & & \\
\hline & & (19 DVA) & yes & no & no \\
\hline \multirow[t]{2}{*}{17} & Hattan Road - Shiloh to Gronlund Roads & 2.2 & 26 & 14 & \\
\hline & & (27 DVA) & yes & (11 DVA) & no \\
\hline \multirow[t]{2}{*}{18} & Green Mountain - Tiny to Gray's Mill/Schieffer Roads & 2.6 & 33 & & \\
\hline & & (22 DVA) & yes & no & no \\
\hline \multirow[t]{2}{*}{19} & Pete's Mountain - Hoffman to Schaeffer to Big Fir Roads & 2.5 & 39 & & \\
\hline & & (23 DVA) & yes & no & no \\
\hline
\end{tabular}


Table F.3. Hotspots with < 16 DVA identified by Crimestat III nearest neighbor routine: location, \# DVA, and DVA density. $\mathrm{SR}=$ search radius.

\begin{tabular}{|c|c|c|c|c|}
\hline Location & (\# DVA) & $\begin{array}{l}\text { Site \# } \\
\geq 10 \mathrm{DVA} \\
0.5 \mathrm{mi} \mathrm{SR} ?\end{array}$ & $\begin{array}{l}\text { Site \# } \\
\geq 10 \text { DVA } \\
0.25 \mathrm{mi} \mathrm{SR} ? \\
\text { or (\# DVA) }\end{array}$ & $\begin{array}{l}\text { Site \# } \\
\geq 10 \text { DVA } \\
0.125 \text { mi SR? } \\
\text { or (\# DVA) }\end{array}$ \\
\hline \multirow[t]{2}{*}{ Lower Highland Road - Rutherford Lane to Logan Drive } & (15 DVA) & 21 & & \\
\hline & & yes & no & no \\
\hline \multirow[t]{2}{*}{ Leland Road - Milligan Road to Foothills Avenue } & (15 DVA) & 23 & & \\
\hline & & yes & no & no \\
\hline \multirow[t]{2}{*}{ Stafford Road - Blackberry Lane to Gage Road } & (14 DVA) & 24 & & \\
\hline & & yes & no & no \\
\hline \multirow[t]{2}{*}{ Springwater Road - Hayden to Jubb Roads } & (15 DVA) & 25 & & \\
\hline & & yes & no & no \\
\hline \multirow[t]{2}{*}{ Wildcat Mountain Drive - Mattson Lane to River Ranch Road } & (14 DVA) & 27 & & \\
\hline & & yes & no & no \\
\hline \multirow[t]{2}{*}{ Wright/Feyrer Park Roads to Feyrer Park/Shady Dell Roads } & (15 DVA) & 28 & & \\
\hline & & yes & no & no \\
\hline \multirow[t]{2}{*}{ Beavercreek Road - Rockie Drive to Norry Court } & (14 DVA) & 29 & & \\
\hline & & yes & no & no \\
\hline \multirow[t]{2}{*}{ Mulino Road - Blundell Road to Adkins Circle } & (15 DVA) & 30 & & \\
\hline & & yes & no & no \\
\hline
\end{tabular}




\begin{tabular}{|c|c|c|c|c|}
\hline Location & (\# DVA) & $\begin{array}{l}\text { Site \# } \\
\geq 10 \mathrm{DVA} \\
0.5 \mathrm{mi} \mathrm{SR} ?\end{array}$ & $\begin{array}{l}\text { Site \# } \\
\geq 10 \text { DVA } \\
0.25 \text { mi SR? } \\
\text { or (\# DVA) }\end{array}$ & $\begin{array}{l}\text { Site \# } \\
\geq 10 \text { DVA/ } \\
0.125 \text { mi SR? } \\
\text { or (\# DVA) }\end{array}$ \\
\hline \multirow[t]{2}{*}{ South End Road - Rocky Bluff Lane to Highway 99E } & (13 DVA) & 31 & & \\
\hline & & yes & no & no \\
\hline \multirow[t]{2}{*}{ Upper Highland Road - Moehnke Drive to Look Road } & (13 DVA) & 32 & & \\
\hline & & yes & no & no \\
\hline \multirow[t]{2}{*}{ Graham and Butteville Roads intersection } & (12 DVA) & 34 & 16 & \\
\hline & & yes & (11 DVA) & no \\
\hline \multirow[t]{2}{*}{ Bakers Ferry Road - Harding to Gerber Roads } & (13 DVA) & 35 & & \\
\hline & & yes & no & no \\
\hline \multirow[t]{2}{*}{ Beavercreek Road - Old Acres Lane to Clairmont Court } & $(12 \mathrm{DVA})$ & 36 & & \\
\hline & & yes & no & no \\
\hline \multirow[t]{2}{*}{21555 S. Redland Road to 22404 S. Redland Road } & (12 DVA) & 37 & & \\
\hline & & yes & no & no \\
\hline \multirow[t]{2}{*}{ Mollala/Mollala Forest Roads to Sawtel1/Herman Roads } & (13 DVA) & 38 & & \\
\hline & & yes & no & no \\
\hline \multirow[t]{2}{*}{ Mountain Road - Stafford to Homesteader Roads } & (11 DVA) & 40 & & \\
\hline & & yes & no & no \\
\hline \multirow[t]{2}{*}{ Sawtell Road - Totem to Bagby Roads } & (11 DVA) & 41 & & \\
\hline & & yes & no & no \\
\hline
\end{tabular}


APPENDIX G

\section{HOTSPOT}

TRAFFIC CONDITIONS 
Table G.1. Change from 1997-2002 in traffic volume, vehicle speed, \% truck traffic, and road class for the 19 densest DVA hotspots.

Source: Clackamas County Department of Transportation and Development.

\begin{tabular}{|c|c|c|c|c|c|c|c|c|}
\hline $\begin{array}{l}\text { Hotspot } \\
\text { Location/ } \\
\text { Identification } \\
\text { Number }\end{array}$ & $\begin{array}{c}\text { Road } \\
\text { Functional } \\
\text { Class }^{1} \\
1997 / /^{5} 2002\end{array}$ & $\begin{array}{c}\text { 85th } \\
\text { Percentile } \\
\text { Speed(MPH)/ } \\
1997 / 2002\end{array}$ & $\begin{array}{c}\text { Truck } \\
\text { Traffic (\%) } \\
1997 / 2002\end{array}$ & $\begin{array}{c}\mathrm{ADT}^{2} \\
1997 / /^{5} 2002\end{array}$ & $\begin{array}{l}1997 \\
\text { Jan. }\end{array}$ & $\begin{array}{l}\text { Traffic } \\
\text { Nov. }\end{array}$ & $\begin{array}{l}{ }^{5} 2002 \\
\text { Jan. }\end{array}$ & Nov. \\
\hline Henrici Rd/1 & $\mathrm{B} / \mathrm{B}$ & $48 / 53$ & ${ }^{4} \mathrm{ND} / 10.5$ & $1700 / 1700$ & 1735 & 1809 & 1735 & 1809 \\
\hline Union Mills/2 & $\mathrm{B} / \mathrm{B}$ & $56 / 49$ & $11.2 / 15.0$ & $5100 / 5808$ & 5204 & 5426 & 5927 & 6179 \\
\hline Sunnyside $\mathrm{Rd} / 3$ & $\mathrm{~A} / \mathrm{A}$ & $51 / 35$ & $5.8 / 6.0$ & $46000 / 37650$ & 46939 & 48936 & 38418 & 40053 \\
\hline Redland $\mathrm{Rd} / 4$ & $\mathrm{~A} / \mathrm{A}$ & $62 / 59$ & $6.6 / 10.1$ & $3100 / 3100$ & 3163 & 3298 & 3163 & 3298 \\
\hline Sunnyside $R d / 5$ & $\mathrm{~A} / \mathrm{A}$ & $51 / 45$ & $2.1 / 4.6$ & $10750 / 13050$ & 10965 & 11436 & 13316 & 13883 \\
\hline S.W.Rosemont Rd/6 & $\mathrm{B} / \mathrm{B}$ & $\mathrm{ND} / 49$ & $5.8 / 4.5$ & $6150 / 6800$ & 6276 & 6543 & 6939 & 7234 \\
\hline Springwater $\mathrm{Rd} / 7$ & $\mathrm{~A} / \mathrm{A}$ & $53 / 63$ & $6.7 / 9.3$ & $2300 / 2300$ & 2347 & 2447 & 2347 & 2447 \\
\hline Redland Rd/8 & $\mathrm{A} / \mathrm{A}$ & $63 / 48$ & $2.9 / 10.1$ & $5959 / 5500$ & 6081 & 6339 & 5612 & 5851 \\
\hline Harding Rd/9 & $\mathrm{C} / \mathrm{L}$ & $\mathrm{ND} / 31$ & $? / 13.9$ & $770 / 860$ & 786 & 819 & 878 & 915 \\
\hline
\end{tabular}




\begin{tabular}{|c|c|c|c|c|c|c|c|c|}
\hline $\begin{array}{l}\text { Hotspot } \\
\text { Location/ } \\
\text { Identification } \\
\text { Number }\end{array}$ & $\begin{array}{c}\text { Road } \\
\text { Functional } \\
\text { Class }^{1} \\
1997 /^{5} 2002\end{array}$ & $\begin{array}{c}\text { 85th } \\
\text { Percentile } \\
\text { Speed(MPH)/ } \\
1997 / 52002\end{array}$ & $\begin{array}{c}\text { Truck } \\
\text { Traffic (\%) } \\
1997 / 2002\end{array}$ & $\begin{array}{c}\mathrm{ADT}^{2} \\
1997 / /^{5} \mathbf{2 0 0 2}\end{array}$ & $\begin{array}{l}1997 \\
\text { Jan. }\end{array}$ & $\begin{array}{l}\text { Traffic } \\
\text { Nov. }\end{array}$ & $\begin{array}{l}e^{5} \\
{ }^{2002} \\
\text { Jan. }\end{array}$ & Nov. \\
\hline Bradley $\mathrm{Rd} / 10$ & $\mathrm{C} / \mathrm{C}$ & $47 / 48$ & $6.8 / 8.4$ & $850 / 1000$ & 867 & 904 & 1020 & 1064 \\
\hline South End Rd/11 & $\mathrm{B} / \mathrm{B}$ & $39 / 52$ & $5.3 / 10.0$ & $2650 / 2600$ & 2704 & 2819 & 2653 & 2766 \\
\hline S.E. 97 th Ave/Mather Rd/12 & $\mathrm{C} / \mathrm{C}$ & $\mathrm{ND} / 41$ & $? / 6.5$ & $\mathrm{ND} / 9050$ & ND & ND & 9234 & 9628 \\
\hline Spangler $\mathrm{Rd} / 13$ & $\mathrm{~B} / \mathrm{B}$ & $60 / 64$ & $8.1 / 15.1$ & $940 / 750$ & 959 & 1000 & 765 & 798 \\
\hline S. Beavercreek Rd/14 & $\mathrm{B} / \mathrm{B}$ & $61 / 50$ & $7.2 / 10.2$ & $5250 / 4250$ & 5357 & 5585 & 4337 & 4521 \\
\hline Advance $\mathrm{Rd} / 15$ & $\mathrm{~B} / \mathrm{B}$ & $\mathrm{ND} / 53$ & $\mathrm{ND} / 6.0$ & $670 / 830$ & 683 & 710 & 847 & 880 \\
\hline Stafford $\mathrm{Rd} / 16$ & $\mathrm{~A} / \mathrm{A}$ & $42 / 45$ & $8.4 / 7.5$ & $10300 / 10750$ & 10506 & 10918 & 10965 & 11395 \\
\hline Hattan $\mathrm{Rd} / 17$ & $\mathrm{~B} / \mathrm{B}$ & $48 / 49$ & $9.4 / 12.0$ & $1950 / 1450$ & 1989 & 2067 & 1479 & 1537 \\
\hline Green Mountain Rd/18 & $\mathrm{ND} / \mathrm{ND}$ & ND/ND & ND/ND & $1250 / 870$ & 1275 & 1325 & 887 & 922 \\
\hline Pete's Mountain Rd/19 & $\mathrm{B} / \mathrm{B}$ & $\mathrm{ND} / 47$ & $\mathrm{ND} / 10.5$ & $1350 / 1150$ & 1377 & 1431 & 1173 & 1219 \\
\hline
\end{tabular}


${ }^{\mathrm{I}}$ Road Functional Classes (source: 2002 Daily Traffic Volume and Road Classification Map, Clackamas County Department of Transportation and Development).

A - Major Arterial: Carries local and through traffic to and from destinations outside local community. Connects cities and rural centers. Moderate to heavy volume; moderate to high speed.

B - Minor Arterial: Connects collectors to higher order roadways. Carries moderate volume at moderate speed.

C - Collector: Principle carrier within neighborhoods or single land use areas. Links neighborhoods with major activity centers and arterials. Low to moderate volume, low to moderate speed.

L - Local: Provides access to abutting property and connects to higher order roads.

${ }^{2} \mathrm{ADT}$ - Average Daily Traffic. ADT=raw daily traffic volume $\mathrm{X}$ axel factor (1.00-\% truck traffic) $\mathrm{X}$ monthly traffic count factor ${ }^{3}$

${ }^{3}$ Monthly Traffic Count Factors for 2005

$\begin{array}{lll}\text { Month } & \text { Urban } & \text { Rural } \\ \text { January } & 1.09 & 1.10 \\ \text { February } & 1.05 & 1.04 \\ \text { March } & 1.04 & 1.03 \\ \text { April } & 1.02 & 0.99 \\ \text { May } & 0.99 & 0.94 \\ \text { June } & 0.94 & 0.92 \\ \text { Juily } & 0.93 & 0.90 \\ \text { August } & 0.97 & 0.92 \\ \text { September } & 0.97 & 0.94 \\ \text { October } & 1.00 & 1.02 \\ \text { November } & 1.02 & 1.06 \\ \text { December } & 1.05 & 1.09\end{array}$

${ }^{4} \mathrm{ND}-\mathrm{No}$ data available 